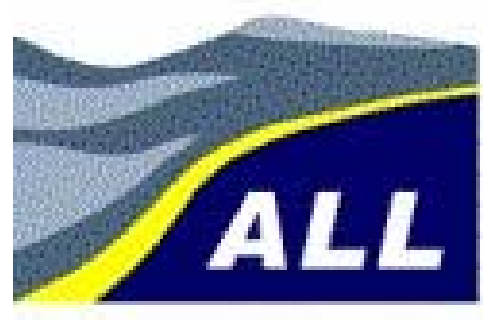

Consulting

\author{
Technical Report
}

\title{
Project Final Report Remediation of Leon Water Flood, Butler County, Kansas
}

Prepared for the

Kansas Corporation Commission

Wichita, Kansas

March, 2003

Prepared by Arthur Langhus Layne - LLC 1305 E. 15 $5^{\text {th }}$ Street, Suite 205

Tulsa, Oklahoma 74120

(918) 740-9930

www.ALL-LLC.com 


\section{TITLE PAGE}

\section{Project Report: Applied Phyto-Remediation Techniques Using Halophytes for Oil and Brine Spill Scars}

\section{Final Report}

Reporting Period: August 2000 to March 2003

\section{Principal Authors:}

- M. L. Korphage, Director, Kansas Corporation Commission, Oil and Gas Division

- Bruce G. Langhus, ALL Consulting

- Scott Campbell, Kansas Biological Survey

March, 2003

Cooperative Agreement No. DE-FC26-00BC15328

M.L. Korphage

Kansas Corporation

Commission

130 S. Market St.

Wichita, KS 67202
B. G. Langhus ALL Consulting 1305 East 15 ${ }^{\text {th }}$

Suite 205

Tulsa, OK 74120
Scott Campbell

Kansas Biological

Survey

University of Kansas

2835 Irvinghill Rd

Lawrence, KS 75320 


\section{Disclaimer:}

This report was prepared as an account of work sponsored by an agency of the United States Government. Neither the United States Government nor any agency thereof, nor any of their employees, makes any warranty, express or implied, or assumes any legal liability or responsibility for the accuracy, completeness, or usefulness of any information, apparatus, product, or process disclosed, or represents that its use would not infringe privately owned rights. Reference herein to any specific commercial product, process, or service by trade name, trademark, manufacturer, or otherwise does not necessarily constitute or imply its endorsement, recommendation, or favoring by the United States Government or any agency thereof. The views and opinions of authors expressed herein do not necessarily state or reflect those of the United States Government or any agency thereof. 


\begin{abstract}
Produced salt water from historical oil and gas production was often managed with inadequate care and unfortunate consequences. In Kansas, the production practices in the 1930's and 1940's - before statewide anti-pollution laws - were such that fluids were often produced to surface impoundments where the oil would segregate from the salt water. The oil was pumped off the pits and the salt water was able to infiltrate into the subsurface soil zones and underlying bedrock. Over the years, oil producing practices were changed so that segregation of fluids was accomplished in steel tanks and salt water was isolated from the natural environment. But before that could happen, significant areas of the state were scarred by salt water. These areas are now in need of economical remediation.
\end{abstract}

Remediation of salt scarred land can be facilitated with soil amendments, land management, and selection of appropriate salt tolerant plants. Current research on the salt scars around the old Leon Waterflood, in Butler County, Kansas show the relative efficiency of remediation options. Based upon these research findings, it is possible to recommend cost efficient remediation techniques for slight, medium, and heavy salt water damaged soil.

- Slight salt damage includes soils with Electrical Conductivity (EC) values of 4.0 $\mathrm{mS} / \mathrm{cm}$ or less. Operators can treat these soils with sufficient amounts of gypsum, install irrigation systems, and till the soil. Appropriate plants can be introduced via transplants or seeded.

- Medium salt damage includes soils with EC values between 4.0 and $16 \mathrm{mS} / \mathrm{cm}$. Operators will add amendments of gypsum, till the soil, and arrange for irrigation. Some particularly salt tolerant plants can be added but most planting ought to be reserved until the second season of remediation

- Severe salt damage includes soil with EC values in excess of $16 \mathrm{mS} / \mathrm{cm}$. Operators will add at least part of the gypsum required, till the soil, and arrange for irrigation. The following seasons more gypsum will be added and as the soil EC is reduced, plants can be introduced.

If rapid remediation is required, a sufficient volume of topsoil, or sand, or manure can be added to dilute the local salinity, the bulk amendments tilled into the surface with added gypsum, and appropriate plants added. In this case, irrigation will be particularly important. The expense of the more rapid remediation will be much higher. 
TITLE PAGE

\section{TABLE OF CONTENTS}

ABSTRACT

$\begin{array}{ll}\text { INTRODUCTION } & 7\end{array}$

$\begin{array}{ll}\text { EXECUTIVE SUMMARY } & 7\end{array}$

$\begin{array}{lr}\text { EXPERIMENTAL } & 12\end{array}$

INITIAL SOIL CHARACTERIZATION AT THE START

OF THE PROJECT-April $2001 \quad 12$

TANK SCAR $\quad 15$

LARGE SCAR

SOIL CHARACTERIZATION AFTER ONE

GROWING SEASON - October $2001 \quad 25$

TANK SCAR $\quad 25$

LARGE SCAR $\quad 29$

SOIL REMEDIATION DURING THE SECOND SEASON -

APRIL TO OCTOBER, $2002 \quad 29$

TANK SCAR $\quad 29$

LARGE SCAR $\quad 29$

Soil Treatments $\quad 29$

Irrigation $\quad 31$

Test-Plot Design $\quad 32$

IMPOUNDMENT ON THE WEST SCAR 34

SOIL CHEMISTRY AT THE END OF THE

SECOND GROWING SEASON

Soil Chemistry in Test-Plots Receiving Bulk Soil Amendments $\quad 35$

Soil Chemistry in Control Test-Plots $\quad 37$

Soil Chemistry and Irrigation $\quad 39$

Soil Remediation Successes $\quad 40$

RESULTS AND DISCUSSION

SURFACE WATER CHARACTER

Specific Conductance $\quad 42$

Dissolved Oxygen $\quad 44$

pH $\quad 45$

Turbidity $\quad 46$

$\begin{array}{lr}\text { Salinity } & 46\end{array}$

$\begin{array}{lr}\text { Temperature } & 46\end{array}$ 
PLANT CENSUS AT THE END OF THE FIRST GROWING SEASON 46

PLANT CENSUS AT THE END OF THE SECOND GROWING SEASON 49

SALINITY ANALYSES OF PLANT TISSUE

REVEGETATION RECOMMENDATIONS

CONCLUSIONS RECOMMENDED REMEDIATION PROCEEDURES 54 Conclusions $\quad 54$

Soil Characterization $\quad 54$

Soil Remediation $\quad 55$

Specification of Soil Amendments $\quad 56$

Revegetation Recommendations $\quad 56$

$\begin{array}{ll}\text { Irrigation Recommendations } & 57\end{array}$

REFERENCES

$\begin{array}{lr}\text { APPENDIX I - Soil Sample Laboratory Data } & 60\end{array}$

APPENDIX II - Leon Surface Water Quality Data 63

APPENDIX III - Plant Census Data $\quad 72$ 


\section{INTRODUCTION}

The Leon Water Flood is the subject of a US DOE grant to research phyto-remediation Best Management Practices of brine-impacted soil. This is a final status report through the end of the research in 2002. The report characterizes local impacted soil as well as its vegetative cover and the changes that have taken place during remediation spanning two growing seasons. The research work and following report are the results of the combined efforts of the Kansas Corporation Commission (KCC), Kansas Biological Survey (KBS), and ALL Consulting-LLC (ALL).

\section{EXECUTIVE SUMMARY}

Historical oil and gas production practices in Kansas and other states in the United States in the first half of the $20^{\text {th }}$ Century resulted in damage to surface soil. Production was often carried out in the absence of relevant state anti-pollution laws such as exist at the present day. As is the case in most of the world's oil reservoirs, at some point in their history, they begin to produce large volumes of water, often 50 times more water than oil. Without regulatory control, the oil and water is sometimes released onto the surface in unlined pits. It was the use of these pits that gave rise to scarring of the land.

The scars are areas where salt water and crude oil have sterilized the soil by the action of two pollutants - salinity and sodium. The salinity prevents seeds from germinating and existing plants from thriving. The sodium acts on the clays in the soil, making them swell and destroying the structure of the soil. The destruction of the soil structure makes the soil "tight" and prevents the soil from transmitting water into the soil or to roots in the soil zone. Remediation must address both aspects of salt scarring. The subject research prioritizes the various remediation techniques to rank their effectiveness and efficiency in Kansas.

A large, orphan, scarred area was marked off into 36 test-plots that were treated to several remedial schemes including gypsum applications, manure, topsoil, salt tolerant plants, and irrigation. At the end of the second growing season, the soil chemistry of the plots was compared to pre-treatment levels to determine the effect of the various treatments. The treatments were also compared to the success of the plants and the relative costs of the treatments.

Some test-plots were diluted with large volumes of clean topsoil, sand or manure. These treatments were successful merely from the dilution action that lowered salinity and sodium concentrations. These treatments were very expensive, however. Treating a large scar with this method, although it would achieve rapid results would be very expensive. Other treatments including only gypsum, tillage, and irrigation were also evaluated. All of these simple processes were effective and economical. Even in a reasonably wet part of Kansas, irrigation augmented the action of other treatments.

Recommendations will vary depending upon the severity of the soil impacts.

- Mild impacts can be defined by their salinity that will only slightly retard growth of suitably tolerant plants. Mild impacts require gypsum, tillage, and water to promote 
leaching and the growth of groundcover. Mildly impacted soils can be planted and seeded immediately.

- Moderate impacts contain salinities that retard the growth of most plants. After the application of gypsum and other soil amendments, halophyte plants can be sprigged and supported by irrigation.

- Severely impacted soils retard the growth of virtually all plants. Seeding and planting should wait until remediation proceeds. Soil amendments will be needed for several seasons. Irrigation will be especially important. At the end of the first year, the soil may be amendable to planting with halophytes to protect the soil from erosion and improve permeability.

Remediation recommendations can be given based upon severity of soil impact. The information derived from the research can be used by operators and landowners to put together a remediation plan for a specific scar.

\section{Historical Practices at the Leon Waterflood Site}

Historical oil production has been done at the Leon site since the 1920's with intensive water flood operations being carried on from the 1960's until the field was abandoned in the 1980's. Several separation pits were used onsite during production. These pits were used to hold the large volumes of produced salt water/crude oil emulsion. Gravity separation in the pits allowed water-free oil to be pumped off while salt water continued to infiltrate into the soil and underlying bedrock. Several pits were located in the area of the Large Scar and one in the area of the Tank Scar. The Tank Scar was also the site of continued leaks from the large wooden tank that once stood on the site. These releases of salt water resulted in the profound impacts to the soil under the scars. Typical scarring can be seen in Figure 1 below. It is these impacts that are the targets of the remediation research.

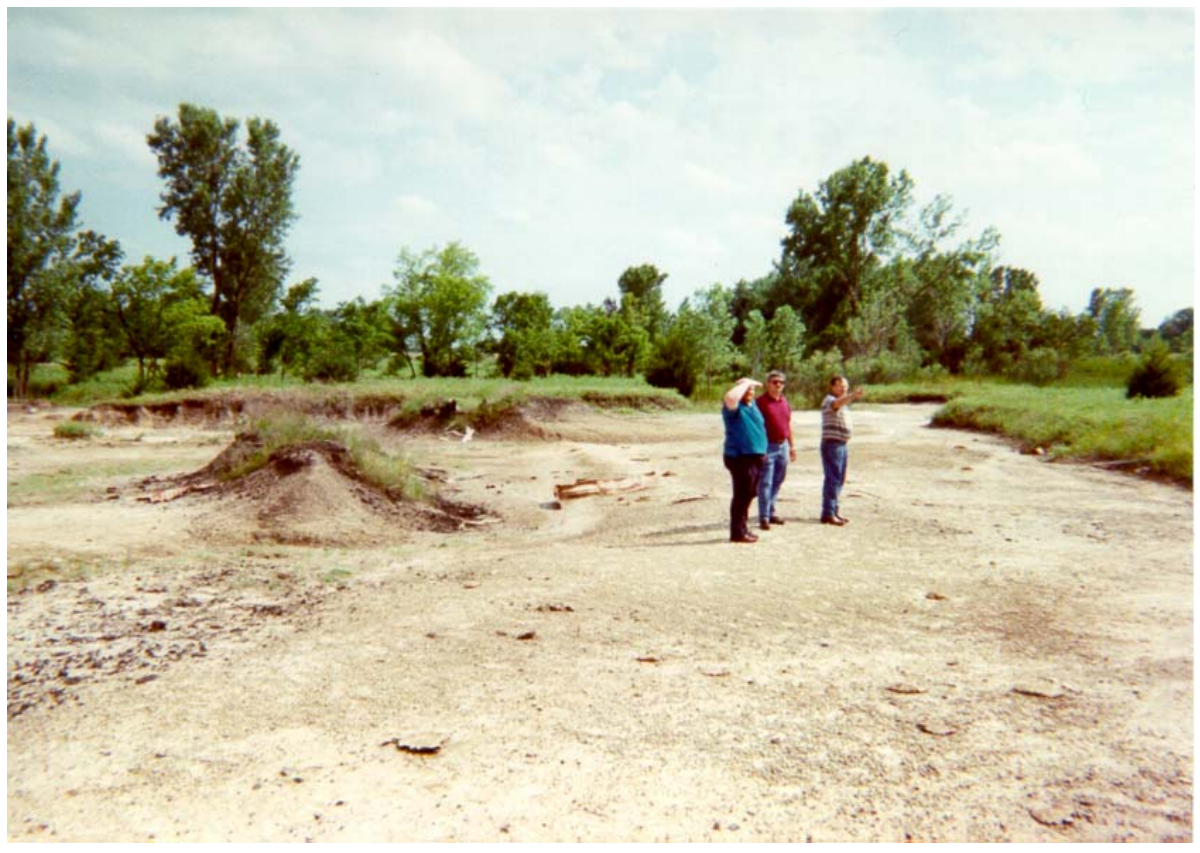




\section{Figure 1: Salt scarring and deep erosion within the Large Scar at the Leon Waterflood site}

\section{Progression of Salt Scarring}

Over time, salt water releases will kill plants and destroy soil structure, which can result in serious erosion and pollution of waterways. The end result of a salt water releases is often a dead-spot or scar of waste ground that can only be rehabilitated at great expense. In Kansas, produced salt waters are primarily sodium chloride, or $\mathrm{NaCl}$. The following is a scenario of a salt water release.

- In the weeks following a brine spill, the local vegetation will appear stressed and then die. The high salinity levels result in drought stress to the plant regardless of the amount of moisture or water available.

- With rainfall, salts will spread through the soil, increasing the extent of contamination both in depth and area. Sodium will begin displacing cations such as calcium, magnesium, and potassium in the soil. These nutrients will be leached away from the spill as the salts spread.

- Sodium ions will then move into the pores of the soil. The salinity causes dispersion of clay particles, effectively clogging the soil and blocking the movement of water and air through the soil.

- Within a year of the spill, most vegetation in the spill location will be dead, depending on spill severity. Most plants will be unable to survive the high salt levels, and salt crusts on the soil may keep seeds from germinating. If the spill is minor, some salt tolerant plants may have appeared. The extent of the site will have spread, and the soil will appear lighter in color due to oxidation and the presence of salt crystals on the surface.

- Erosion will then become a problem; gullies and rills will be visible in the site. After only one year, remediation has become a challenge. In the rare event that the site has very good drainage, coarse soil, and high rainfall, nature may be able to take its course in repairing the site, but these conditions are rare in Kansas. If drainage is poor, the soil is fine textured, and rainfall is low, the site can only be remediated through great effort.

- In the years and decades to follow, the spill site will typically appear as a dead, bare area. All the topsoil will have eroded leaving only subsoil or bedrock. The deep gullies formed by erosion may extend well beyond the original site location. The salts and silts from the spill site have already entered nearby water supplies, with detrimental effects to water quality, aquatic life, and aquifers.

\section{Impacts of Salt Scarring}

The initial impact of a brine spill is destruction of the local plant community. In Kansas where $90 \%$ of the native prairie plant community is gone and most oil production occurs in a prairie setting conservation impacts could be severe. Loss of the plant community results in a near-complete loss of wildlife habitat for many animal species. Erosion follows loss of the vegetation, including loss of rich Kansas topsoil essential for agricultural production and grazing. Denuded of vegetation and typified by deeply eroded gullies, old brine scars also detract from the beauty of the Kansas landscape. 
Watershed impacts are among the legacies of brine spills. Salts are leached into nearby streams, ponds and rivers. They may infiltrate into the local groundwater. Erosion results in discharge of silts and sediments into local streams, which impacts water quality, aquatic life, and stream flow.

Brine impacts to land and water result in serious economic consequences. Land affected by an untreated brine spill is unavailable for most other uses. This area has lost much of its agricultural value, since it is no longer suitable for crop production and may not suitable for grazing, and is less valuable for hunting, camping, or recreation. The damaged land is an eyesore and its property value may therefore be seriously reduced. The loss of aquatic life in nearby streams, plus reduced water quality due to erosion and leached salts, limits recreation and fishing opportunities. In some cases, brine pollutes drinking water supplies. For example, saltwater contamination of municipal water rendered some water wells unusable in the 1980s in Franklin County, Kansas. All of these impacts are economically detrimental. Finally, cleanup of such damage is extremely difficult and cannot be undertaken without substantial time and monetary commitment.

Produced salt water can impact surface soil by rendering the soil sterile because of excess salinity and by making it impermeable to water due to an excess of sodium. In order to return the soil to productivity and provide sufficient groundcover, both conditions must be remediated; sufficient salt must be removed so that plants can grow and permeability must be improved so that rain water can enter the soil.

\section{Remediation of Salt Scars}

Remediation of salt scars can be approached on the basis of severity of impact as indicated by surface soil salinity. Unless surface soil can be remediated, seeds will not germinate and even salt-tolerant transplants will not become established. Remediation of the root-zone - surface soil - can be achieved by leaching salinity down into lower reaches of the subsoil or into bedrock. In order for this to happen, water must be available and vertical permeability must exist in the soil profile. Either sufficient precipitation can provide water or an irrigation option must be installed. Soil permeability can be enhanced through tillage, the addition of soil amendments such as manure or topsoil or sand, or the establishment of growing plants that will send down roots to encourage vertical fluid movement.

Excess sodium in the produced salt water will cause clay minerals to swell within the soil and seal off permeability. This tight soil must be remediated to allow water to move downwards, carrying excess salts out of the surface root-zone. Gypsum is the chemical agent that supplies calcium and magnesium cations to replace sodium in the clay matrix that will increase permeability.

Various remediation techniques have been used, relying on the establishment of salttolerant (halophyte) plant species. The scarred areas have been managed through two growing seasons with varied results. This final project report documents remediation 
from the initial character of the soil and changes after the two growing seasons. The report summarizes the success of soil remediation techniques and the success of various plants across the scarred areas. The report ends by recommending the most successful remediation techniques and the most appropriate plants for use in future remediation projects in Kansas and neighboring areas. 


\section{EXPERIMENTAL}

\section{INITIAL SOIL CHARACTERIZATION AT THE START OF THE PROJECT-April 2001}

The area around the Leon Waterflood has produced oil for over 60 years. The area contains numerous small and large scars caused by various historic oilfield activities. A large portion of the general area was covered by oil production, tank batteries, pipelines, and lease roads. The Leon site itself was dominated by three prominent salt scars caused by historical oil production - the West Scar, the Large Scar, and the Tank Scar. These areas are shown in the aerial photo shown as Figure 2 and described below. 


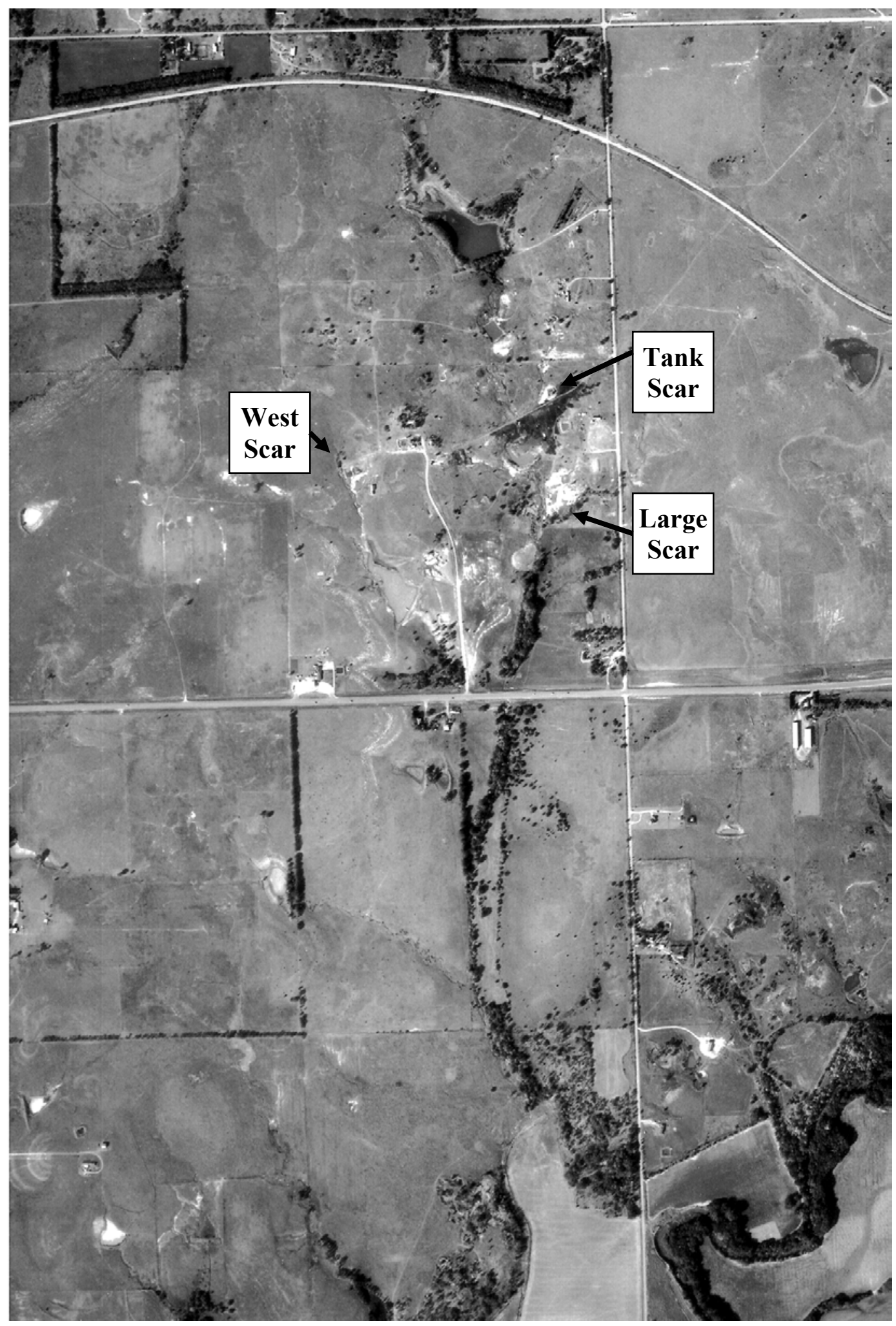

Figure 2: Leon Waterflood Site Showing Areas of Remediation Effort.

- The West Scar is approximately one acre in size but is centered on the small intermittent stream at the edge of the Leon quarter-section. The scar is dominated 
by deep gullies associated with the intermittent stream. The gullies have formed within all of the easily-erodible salt-impacted soil. The gullies range from a foot deep to approximately eight feet deep; some of the deepest gullies have extended down to the flaggy limestone of the local bedrock. Soil depth in this area is very thin on the hills to several feet in the stream alluvium. It was determined that this scar would be too expensive to fill in and establish plant growth. Discussions with the landowner determined that the best way to remediate this land was by constructing an impoundment over the gullied scar.

- The Large Scar is approximately 2.0 acres in size. This feature consists of several coalescing pits, which have been deeply eroded approximately three feet below the height of the intervening berms. Soil depth ranges from a very few inches at its uphill NW side to in excess of four feet on its downhill southern end. This scar is the site of a variety of remediation efforts.

- The Tank Scar is approximately 0.5 acres in size with soil depth being more consistently at approximately three feet. The scar is dominated by an old wooden water tank that sits on a disintegrating concrete pad; the tank contains sludge that is leaking into the scar. The extent of an old pit is also visible within the scar. Remediation efforts involve removal of the tank and tank pad as well as filling in the old pit.

The three scarred areas show similar effects of brine impact. Surface soil is bare of vegetation and cracked. Over much of the scarred areas, erosion has removed most of the soil down to bedrock or the transition from soil to bedrock. Hard, angular chunks of bitumen-impregnated soil are scattered across the surface of these scars. It was decided early to remediate the Tank and Large scars and install a stock-pond over the West scar rather than attempt to fill the deep gullies at that site.

\section{Initial Site Management}

In preparation for remediation activities, site characterization was performed over the two scars. The Large and Tank scars were marked off in a 10-meter grid prior to sampling. A total of 91 soil samples taken from the surface down to 36 inches show total salinities over $30,000 \mathrm{ppm}$ and exchangeable sodium from $0.0 \%$ to over $50 \%$. There appears to be little difference between the soil character and brine impacts in the Large and Tank scars. Before soil was sampled, the Tank Scar and Large Scar were leveled, a slight berm was engineered above (to the NE) the Large Scar to discourage runoff and erosion, and lastly electric fences were installed around the perimeter of each scar to keep livestock out of the remediation area. 
TANK SCAR

Tank Scar was sampled at the surface as detailed in Figures 3 through 6 below:

Figure 3: Surface Soil Electrical Conductivity

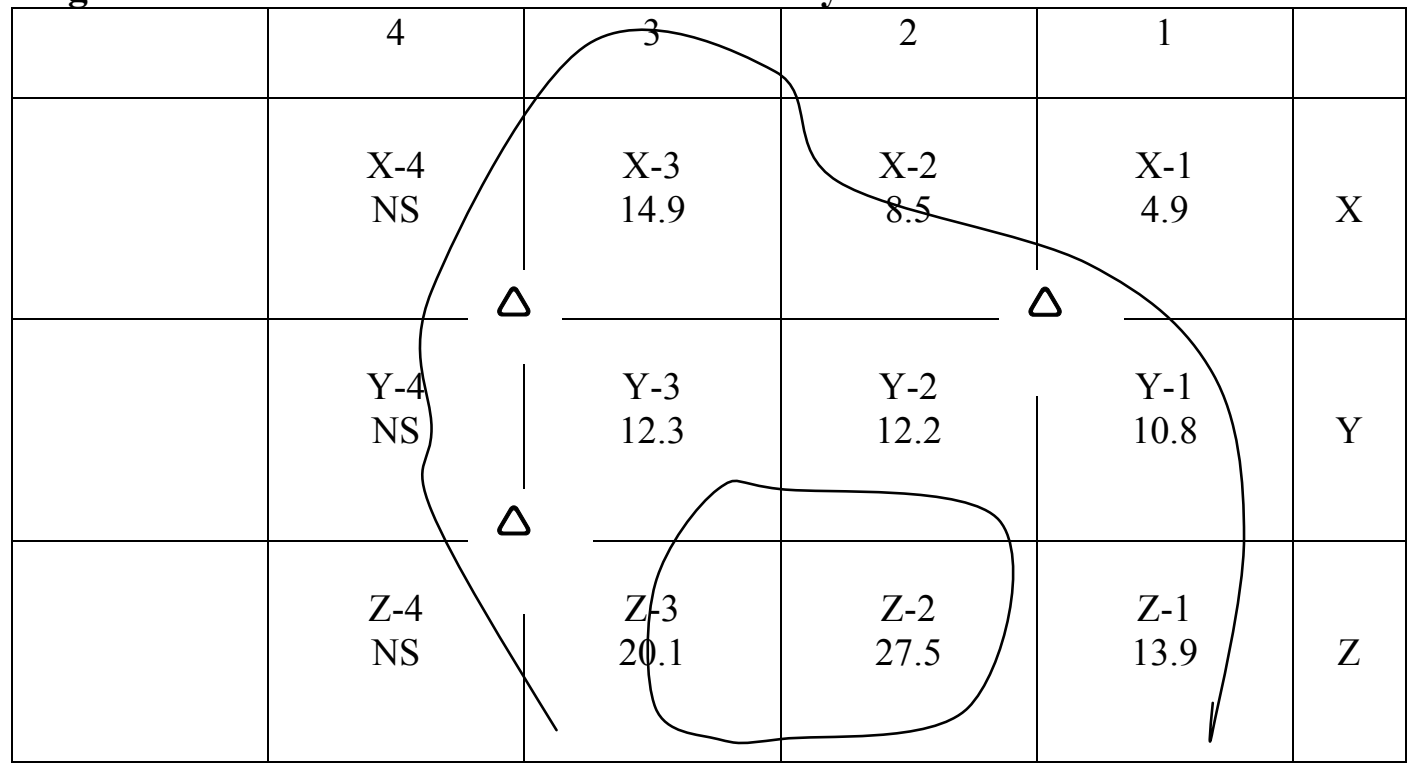

\section{Tank Scar - Leon Water Flood EC - Surface (0 to 6") Soil (mmhos/cm) $\Delta=$ Soil Boring}

Soil sampling was done in April, 2001. Contour Interval is $10 \mathrm{mmhos} / \mathrm{cm}$.

Electrical Conductivity (EC) is a measure of total dissolved salts in soil; salinity is the major source of stress for plants. Threshold levels for salinity stress will vary between plant species. EC values in excess of 4.0 are considered saline (Richards, 1954) and potentially stressful for some varieties of common vegetation. All surface soil samples at the Tank Scar show excessive to very excessive salinity levels and this is corroborated in that only scattered sprouting can be seen at the seeded and mulched scar. Exchangeable sodium is shown in Figure 4 below: 
Figure 4: Surface Exchangeable Sodium in \%

\begin{tabular}{|c|c|c|c|c|c|}
\hline & 4 & 3 & 2 & 1 & \\
\hline & $X-4$ & $\begin{array}{l}\text { X-3 } \\
27.9\end{array}$ & $\begin{array}{l}X-2 \\
202\end{array}$ & $\begin{array}{l}\text { X-1 } \\
17.8\end{array}$ & $\mathrm{X}$ \\
\hline & Y-4 & $\begin{array}{r}\text { Y-3 } \\
25.8\end{array}$ & $\begin{array}{c}\text { Y-2 } \\
27.9\end{array}$ & $\begin{array}{c}\text { Y-1 } \\
18.3\end{array}$ & Y \\
\hline & Z-4 & $\begin{array}{c}\text { Z-3 } \\
33.6\end{array}$ & $\begin{array}{l}\text { Z-2 } \\
54.3\end{array}$ & $\begin{array}{l}\text { Z-1 } \\
24.8\end{array}$ & Z \\
\hline
\end{tabular}

\section{Tank Scar - Leon Water Flood \\ Surface Exchangeable Sodium in \% April 2001 \\ $\Delta=$ Soil Boring}

Soil sampling was done in April 2001. Contour interval is $20 \%$.

Exchangeable Sodium Percentage ESP) is a measure of the sodicity of clays within the soil matrix and the potential for destruction of soil texture from dispersion of the clay particles. Soil ESP is excessive at a value of 15\%; virtually the entire Tank Scar is in excess of $15 \%$. Nevertheless, the site shows little sign of erosion and soil texture shows good infiltration of water and little puddling of rainwater. 
Figure 5: Horizontal Conductivity from EM Survey

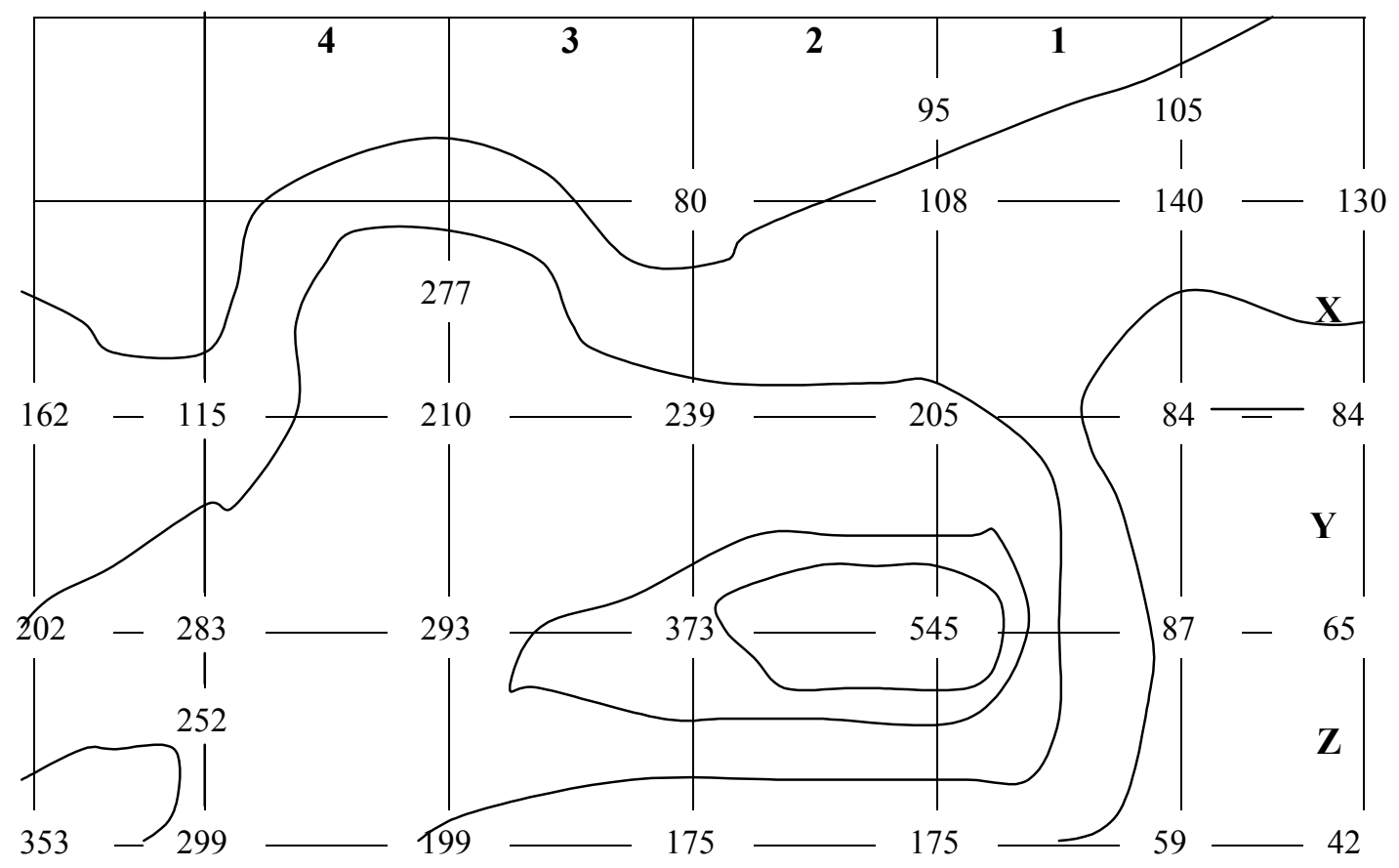

Tank Scar - Leon Water Flood

Horizontal Conductivity from Electro-Magnetics In millisiemens/meter

On April 25, 2001 the NRCS ran a detailed Electro-Magnetic Survey over both scarred areas. Figures 5 and 6 are the E-M results over the Tank Scar. Conductivity closely parallels soil EC results with the largest impact shown beneath the $\mathrm{X}-\mathrm{Y}-2$ location on both E-M Survey data and soil data. 
Figure 6: Vertical Conductivity from EM Survey

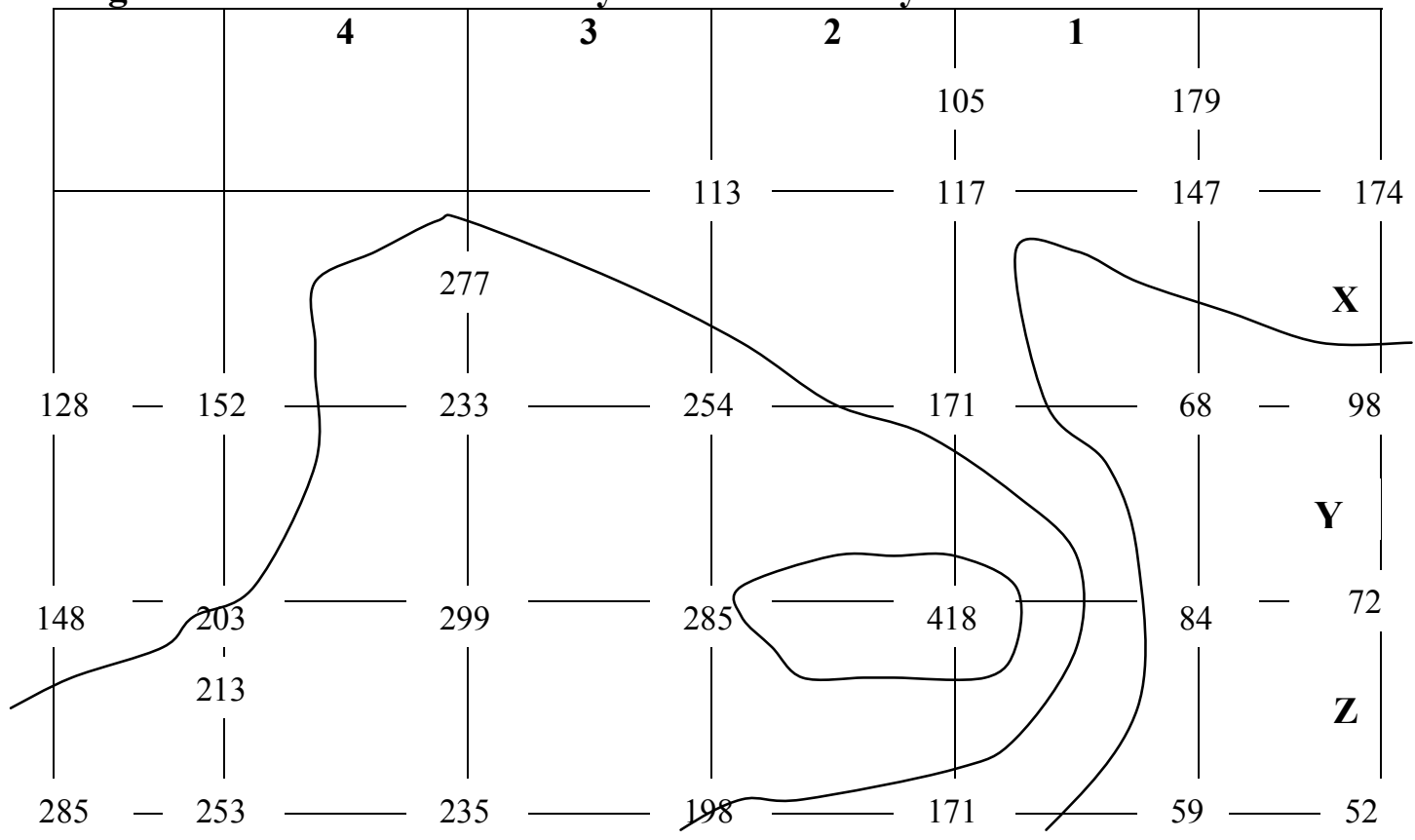

\section{Tank Scar - Leon Water Flood \\ Vertical Conductivity from Electro-Magnetics \\ In millisiemens/meter}

\section{LARGE SCAR}

Figures 7 through 10 map the salinity in the surface soil across the Large Scar. 
Figure 7: EC in the Surface Soil at the Large Scar, Leon Waterflood

\begin{tabular}{|c|c|c|c|c|c|c|}
\hline & $\mathrm{A}$ & B & $\mathrm{C}$ & $\mathrm{D}$ & $\mathrm{E}$ & $\mathrm{F}$ \\
\hline 1 & $\begin{array}{l}\text { A-1 } \\
\text { NS }\end{array}$ & $\begin{array}{l}\text { B-1 } \\
2.6\end{array}$ & $\begin{array}{l}\text { C-1 } \\
2.8\end{array}$ & $\begin{array}{l}\text { D-1 } \\
2.3\end{array}$ & $\begin{array}{c}\text { E-1 } \\
2.3\end{array}$ & $\begin{array}{l}\text { F-1 } \\
1.4\end{array}$ \\
\hline 2 & $\begin{array}{l}\text { A-2 } \\
\text { NS }\end{array}$ & $\begin{array}{l}\text { B-2 } \\
2.4\end{array}$ & $\begin{array}{c}\mathrm{C}-2 \\
4.3\end{array}$ & $\begin{array}{c}\mathrm{D}-2 \\
4.2\end{array}$ & $\begin{array}{l}\text { E-2 } \\
3.2\end{array}$ & $\begin{array}{l}\text { F-2 } \\
3.0\end{array}$ \\
\hline 3 & $\begin{array}{c}\text { A-3 } \\
5.2\end{array}$ & B-3 & $\begin{array}{l}C-3 \\
6.7\end{array}$ & $\begin{array}{l}\text { D-3 } \\
6.2\end{array}$ & $\begin{array}{l}\text { E-3 } \\
4.9\end{array}$ & $\begin{array}{l}\text { F-3 } \\
\text { NS }\end{array}$ \\
\hline 4 & $\begin{array}{l}\text { A. } 4 \\
10.1\end{array}$ & & $\begin{array}{c}\text { C-4 } \\
15.2\end{array}$ & $\begin{array}{l}\text { D-4 } \\
11.9\end{array}$ & $\begin{array}{c}\text { E-4 } \\
5.5\end{array}$ & \\
\hline 5 & $\begin{array}{c}\text { A-5 } \\
8.1\end{array}$ & & $\begin{array}{c}\text { C-5 } \\
14.4\end{array}$ & & $\begin{array}{l}\text { E-5 } \\
\text { NS }\end{array}$ & \\
\hline 6 & $\begin{array}{l}4-6 \\
0.5\end{array}$ & & & $\begin{array}{l}\text { D-6 } \\
12.1\end{array}$ & & \\
\hline 7 & $\begin{array}{c}\text { A-7 } \\
8.2\end{array}$ & & & & $\begin{array}{c}\text { E-7 } \\
17.0\end{array}$ & \\
\hline 8 & $\begin{array}{c}\text { A-8 } \\
6.0\end{array}$ & $\begin{array}{c}\text { B-8 } \\
6.8\end{array}$ & 25.9 & & & 28.8 \\
\hline 9 & $\begin{array}{c}\text { A-9 } \\
5.9\end{array}$ & $\begin{array}{c}\text { B-9 } \\
5.5\end{array}$ & & D. & E-9 & $\begin{array}{l}7-9 \\
15.3\end{array}$ \\
\hline 10 & $\begin{array}{c}\mathrm{A}-10 \\
5.8\end{array}$ & $\begin{array}{c}\text { B-10 } \\
8.2\end{array}$ & & $\begin{array}{l}\mathrm{D}-10 \\
24.0\end{array}$ & $\begin{array}{l}-10 \\
12.4\end{array}$ & $\begin{array}{l}F-10 \\
12.6\end{array}$ \\
\hline
\end{tabular}

\section{Large Scar - Leon Water Flood EC - Surface (0 to 6") Soil (mmhos/cm) $\Delta=$ Soil Boring}

Surface soil sampling was done in April 2001. Contour interval is $10 \mathrm{mmhos} / \mathrm{cm}$.

Electrical Conductivity (EC) shown in Figure 7 is a measure of total dissolved salts in soil; salinity is the major source of stress for plants. Threshold levels for salinity stress will vary between plant species. EC values in excess of 4.0 are considered saline 
(Richards, 1954) and potentially stressful for some varieties of common vegetation. Many surface soil samples at the Large Scar show excessive to very excessive salinity levels and this is corroborated in that only scattered sprouting can be seen at the seeded and mulched scar. Exchangeable sodium is shown in Figure 8 below: 
Figure 8: ESP in Surface Soil at the Large Scar

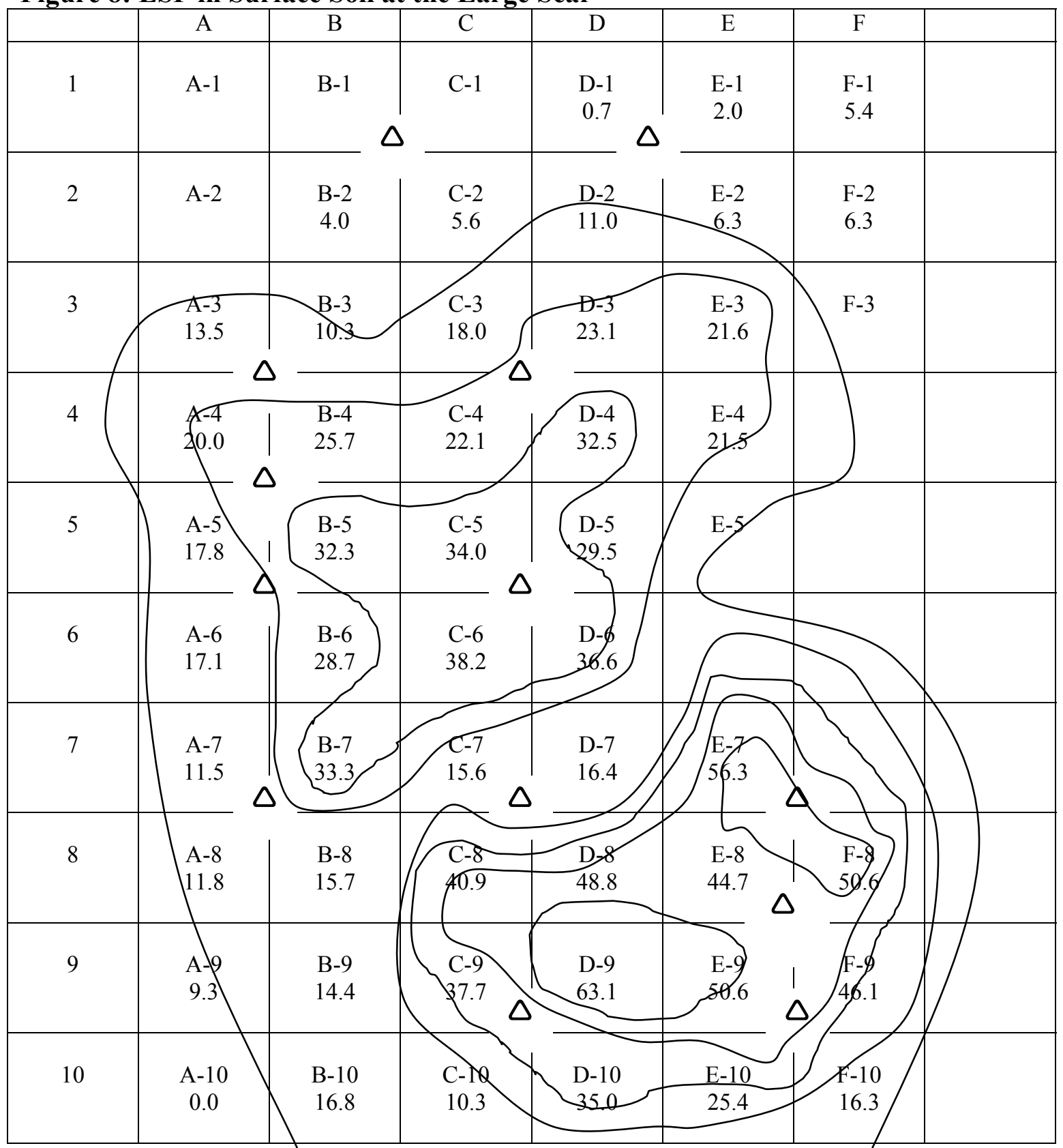

\section{Large Scar - Leon Water Flood Exchangeable Sodium in \% Surface Soil $\triangle=$ Soil Boring}

Surface soil sampling was done in April 2001. Contour interval is 10\%.

EC and ESP in the soil can also be corroborated by remote sensing, including ElectroMagnetic Surveys as shown in Figures 9 and 10. 
Figure 9: Vertical EC from EM Survey

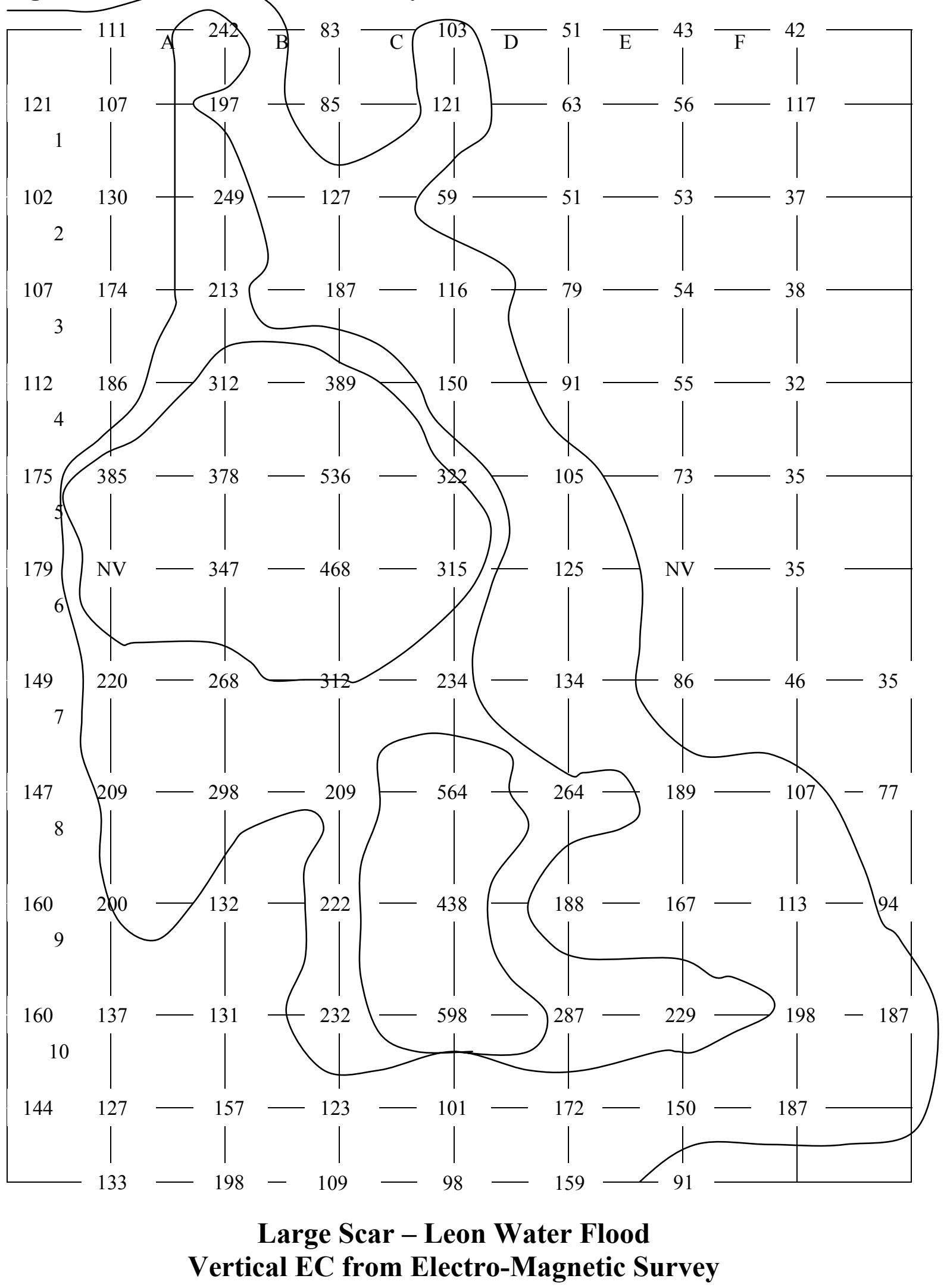


Figure 10: Horizontal EC from E-M Survey

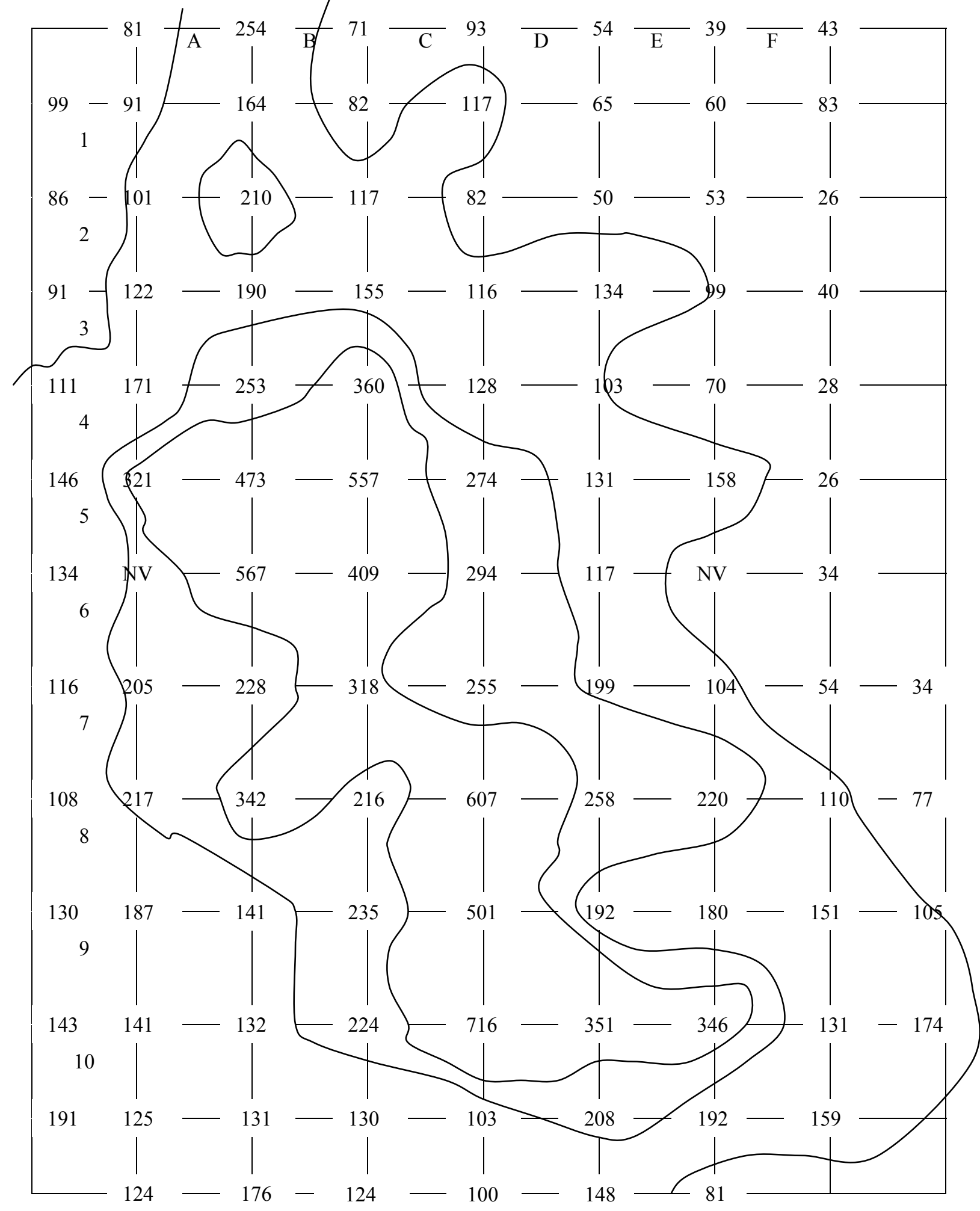

Large Scar - Leon Water Flood

Horizontal EC from Electro-Magnetic Survey 
The EC data derived from Electro-Magnetic survey on April 25, 2001 show rough correlation with soil chemical data. An exception is the highly impacted area shown documented in soil data at approximately block E-7 to F-8. This area is not highlighted on EC data derived from the E-M survey; suggesting that the impacted soil is only shallow. This portion of the Large Scar appears to hold only a shallow soil profile resting on limestone bedrock.

\section{SOIL CHARACTERIZATION AFTER ONE GROWING SEASON -} October 2001

Soil was sampled near the end of the growing season in 2001 to track the remediation progress of surface soil. A spreadsheet of the results appears in the Appendix. The following are mapped values.

\section{TANK SCAR}

Figure 11: Surface Soil Electrical Conductivity

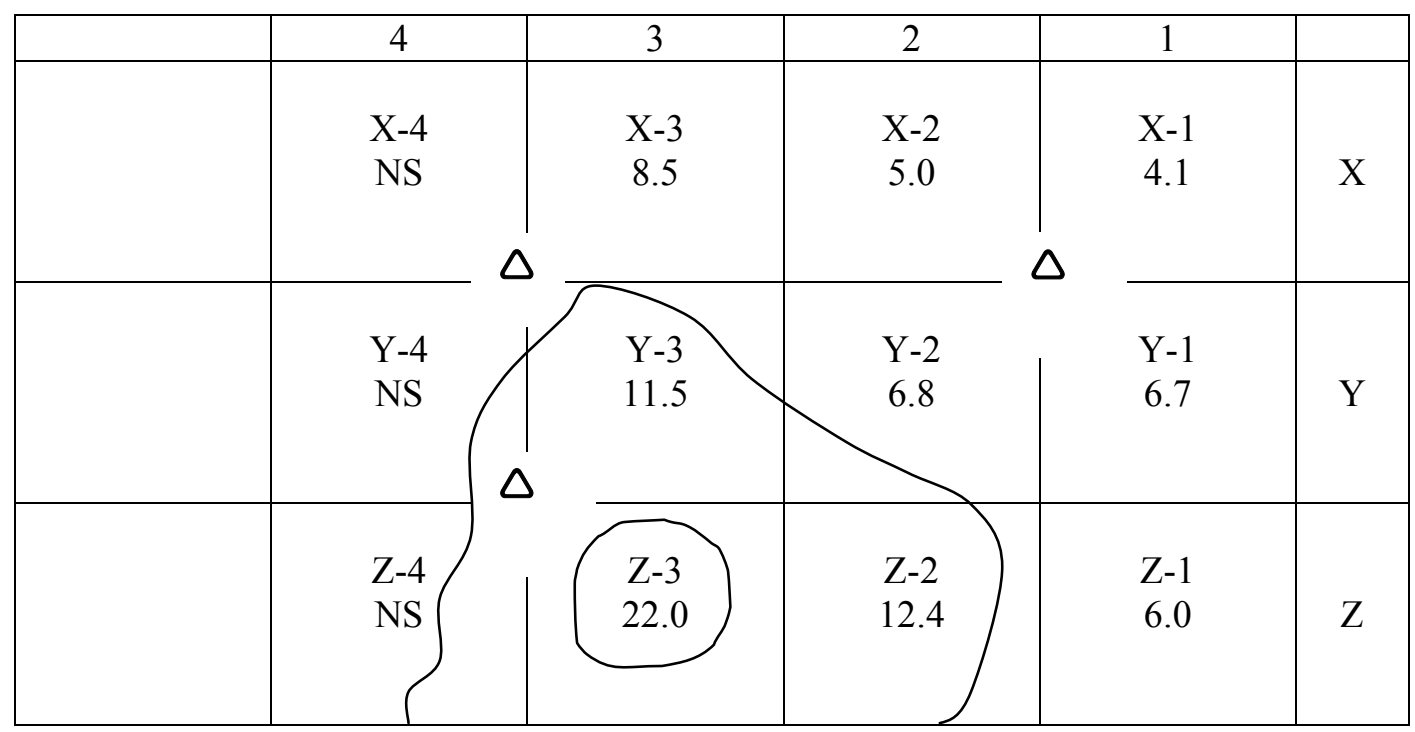

Tank Scar - Leon Water Flood EC (mS/cm) - Surface (0 to 6") Soil (October, 2001) 
Figure 12: Surface Exchangeable Sodium in \%

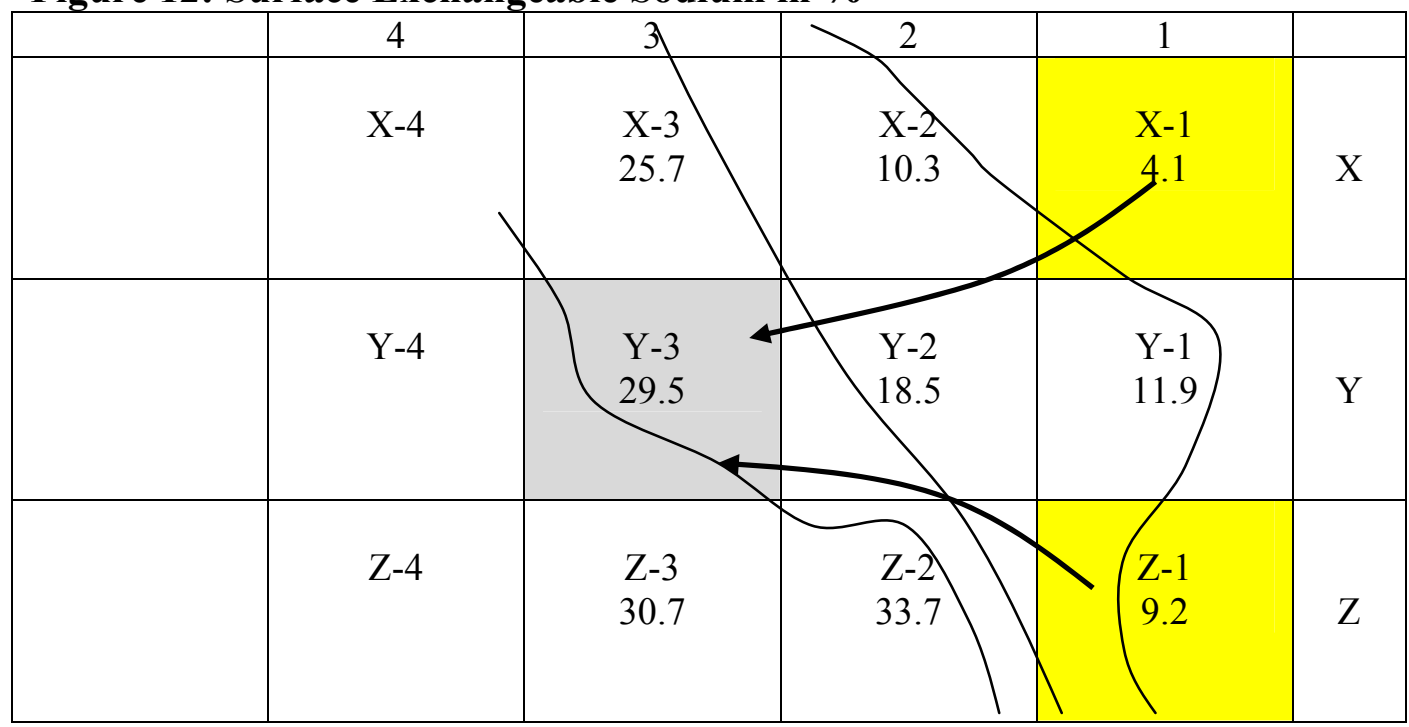

Tank Scar - Leon Water Flood Surface Exchangeable Sodium in \% October 2001 = Sodium increased Since April 2001 Sampling

$\square=$ Sodium Decreased at Least 50\% Since April 2001 Sampling $\longleftarrow=$ Inferred Direction of Surface Leaching

Both EC and exchangeable sodium have declined across most of the Tank Scar. Average EC has declined 34\% from $13.9 \mathrm{mS} / \mathrm{cm}$ in April to $9.2 \mathrm{mS} / \mathrm{cm}$ in October. Exchangeable sodium dropped $31 \%$ from an average of $27.8 \%$ to $19.3 \%$. Figure 12 documents the progress of remediation in the surface soils through the first growing season at the Tank Scar. Sodium ions have been reduced over most of the site with the greatest leaching taking place at the eastern, up-gradient side (X-1 and Z-1), although most of the site is still classified by the KSU Soil Lab as excessively alkaline (over $10.0 \mathrm{mS} / \mathrm{cm}$ ). Leaching has apparently been driven by the flow of surface water to the west and this has enriched the down-gradient area (especially Y-3) in sodium. 
Figure 13: Surface Soil EC

\begin{tabular}{|c|c|c|c|c|c|c|c|}
\hline & $\mathrm{A}$ & B & $\mathrm{C}$ & $\mathrm{D}$ & $\mathrm{E}$ & $\mathrm{F}$ & \\
\hline 1 & $\begin{array}{l}\text { A-1 } \\
\text { NS }\end{array}$ & $\begin{array}{l}\text { B-1 } \\
\text { NS }\end{array}$ & $\begin{array}{l}\text { C-1 } \\
\text { NS }\end{array}$ & $\begin{array}{l}\text { D-1 } \\
\text { NS }\end{array}$ & $\begin{array}{l}\text { E-1 } \\
\text { NS }\end{array}$ & $\begin{array}{l}\text { F-1 } \\
\text { NS }\end{array}$ & \\
\hline 2 & $\begin{array}{l}A-2 \\
\text { NS }\end{array}$ & $\begin{array}{l}\text { B-2 } \\
\text { NS }\end{array}$ & $\begin{array}{l}\text { C-2 } \\
\text { NS }\end{array}$ & $\begin{array}{l}\text { D-2 } \\
\text { NS }\end{array}$ & $\begin{array}{l}\text { E-2 } \\
\text { NS }\end{array}$ & $\begin{array}{l}\mathrm{F}-2 \\
\mathrm{NS}\end{array}$ & \\
\hline 3 & $\begin{array}{c}\text { A-3 } \\
3.9\end{array}$ & $\begin{array}{l}\text { B-3 } \\
2.2\end{array}$ & $\begin{array}{l}C-3 \\
3.0\end{array}$ & $\begin{array}{c}\text { D-3 } \\
3.8\end{array}$ & $\begin{array}{l}\text { E-3 } \\
2.8\end{array}$ & $\begin{array}{l}\text { F-3 } \\
\text { NS }\end{array}$ & \\
\hline 4 & $\begin{array}{c}A-4 \\
9.2\end{array}$ & $\frac{B-4}{12.4}$ & & & $\begin{array}{c}\text { E-4 } \\
3.9\end{array}$ & & \\
\hline 5 & $\begin{array}{c}A-5 \\
8.9\end{array}$ & $\begin{array}{c}\text { B-5 } \\
22.2\end{array}$ & $\begin{array}{l}\text { C-5 } \\
17.3\end{array}$ & & $\begin{array}{l}\text { E-5 } \\
\text { NS }\end{array}$ & & \\
\hline 6 & $\begin{array}{c}\text { A-6 } \\
6.7\end{array}$ & $\begin{array}{c}\text { B-6 } \\
12.8\end{array}$ & & & & & \\
\hline 7 & $\begin{array}{c}\text { A-7 } \\
5.3\end{array}$ & & & & 11.3 & & \\
\hline 8 & $\begin{array}{c}\text { A-8 } \\
4.0\end{array}$ & $\begin{array}{c}\text { B-8 } \\
5.6\end{array}$ & & & 24.5 & $\begin{array}{c}\text { F-8 } \\
24.2\end{array}$ & \\
\hline 9 & $\begin{array}{c}\text { A-9 } \\
4.9\end{array}$ & $\begin{array}{c}\text { B-9 } \\
8.1\end{array}$ & $\begin{array}{l}\text { C-9 } \\
12.2\end{array}$ & 20.8 & & $\begin{array}{c}\text { F-9 } \\
18.5\end{array}$ & \\
\hline 10 & $\begin{array}{c}\text { A-10 } \\
5.2\end{array}$ & $\begin{array}{c}\text { B-10 } \\
6.5\end{array}$ & $\begin{array}{l}\text { C-10 } \\
13.4\end{array}$ & $\begin{array}{l}\text { D-10 } \\
28.7\end{array}$ & $\begin{array}{l}\text { E-10 } \\
24.3\end{array}$ & $\begin{array}{l}\text { F-10 } \\
21.1\end{array}$ & \\
\hline
\end{tabular}

\section{Large Scar - Leon Water Flood}

Surface Soil(0" - 6") Electrical Conductivity (mS/cm) (October 2001)

$\square=$ Increased since April 2001 Sampling 
Figure 14: ESP in Surface Soil, Oct 2001

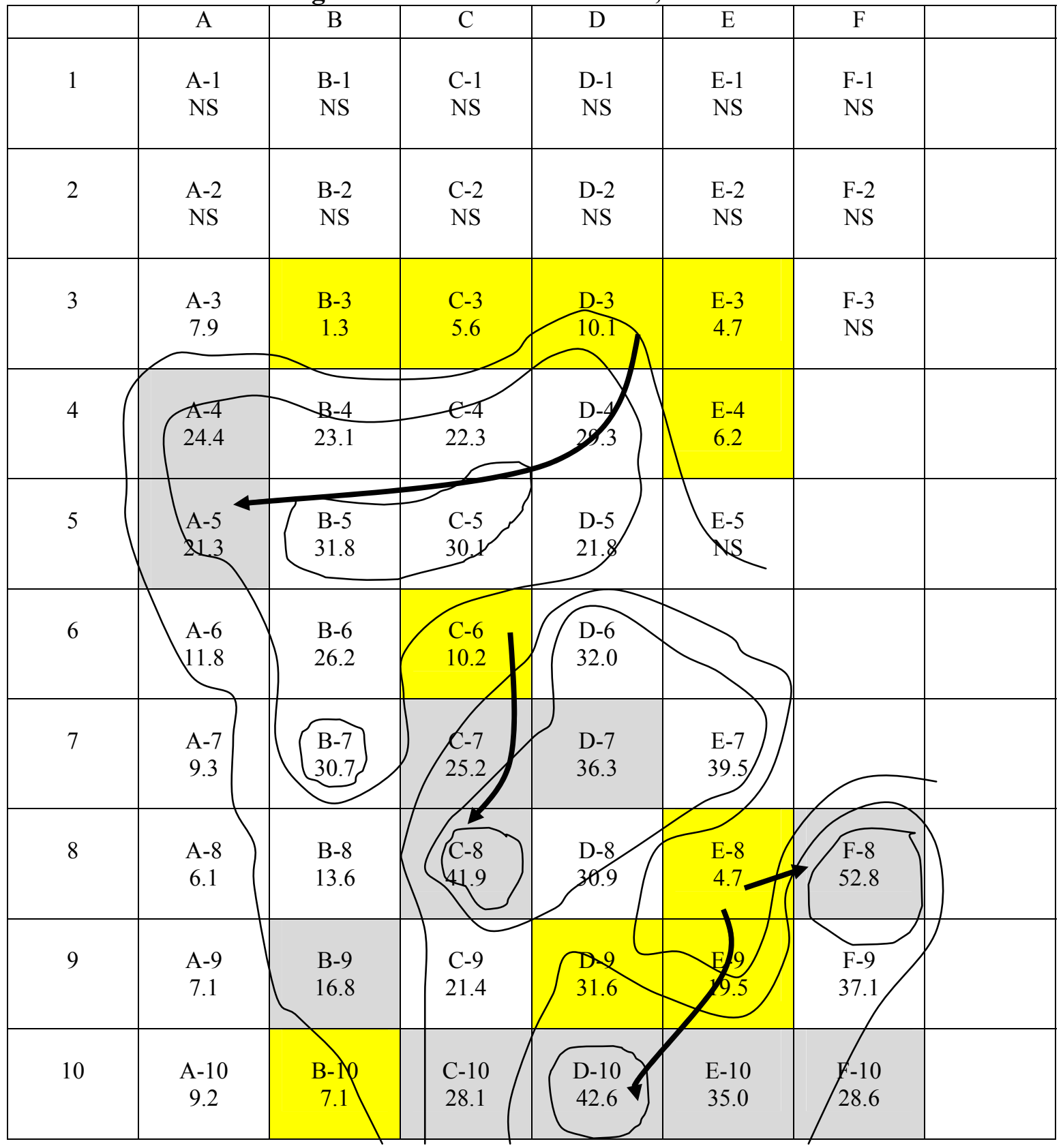

Large Scar - Leon Water Flood

Surface Soil (0" - 6") Exchangeable Sodium Percent (October 2001)

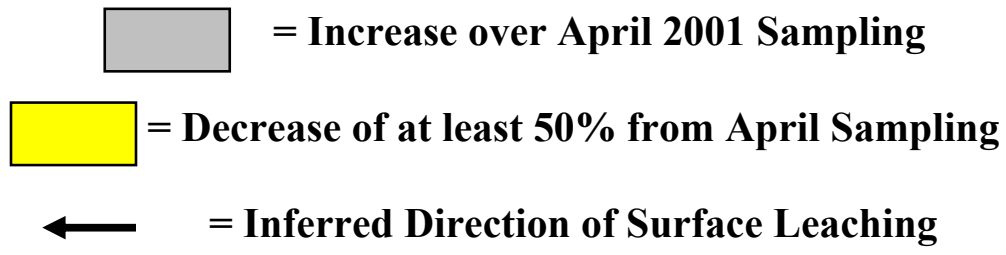




\section{LARGE SCAR}

Surface soil EC reduced an average of $7 \%$ from $13.2 \mathrm{mS} / \mathrm{cm}$ to $12.3 \mathrm{mS} / \mathrm{cm}$. EC is a combination of brine impact to the soil at the beginning of the project plus increases in calcium and sulfate as the gypsum dissolves minus leaching of sodium ions. Modest decreases or even increases in EC are to be expected as dissolution of the gypsum surpasses leaching at the early stage of the process.

Surface soil ESP decreased an average of 22\% from 27.8\% in April 2001 to $21.8 \%$ in October 2001. ESP is the more important parameter and measures the leaching process as sodium is displaced from clay particles by calcium. Figure 13 shows those areas that have been significantly leached of sodium (yellow) and those areas that have been enriched in sodium (gray). Also shown are inferred directions of surface water flow carrying the sodium ions away from leached areas and toward enriched areas. Figure 14 documents the alteration that has happened at the site, at least in the near surface soil, during the past growing season. This alteration has happened despite the relative lack of precipitation during the summer and fall of 2001.

\section{SOIL REMEDIATION DURING THE SECOND SEASON - APRIL TO OCTOBER, 2002 \\ TANK SCAR}

The tank scar was treated as a control for the second season. No additional amendments were applied to the area. The cells in the scar averaged approximately $6 \%$ increase in salinity but this was mostly due to one sample (Y-2) that increased by over $400 \%$ and may have been caused by a statistical aberration. Without the Y-2 sample, the remaining eight Tank Scar samples averaged $19.9 \%$ reduction in EC and are at $7.6 \mathrm{mS} / \mathrm{cm}$. This scar is approaching normal salinity and should support grasses in the near future.

\section{LARGE SCAR \\ Soil Treatments}

The large scar was treated with a variety of soil amendments and preparations arranged in a randomly selected pattern of test-plots. The ten-meter cells laid out for soil sampling the previous year allowed easy location for the test-plots, each of which occupied the NE quarter of the ten-meter cell. Each five-meter square plot then received one of the following soil treatments:

1. Topsoil: Add 6 inches of high-quality, low salinity topsoil

2. Manure: Add manure and deep cultivation (40 tons/acre)

3. Gypsum: Add gypsum and deep cultivation (20 tons/acre)

4. Sand: Add river sand and deep cultivation (1:4 sand/soil ratio)

5. Tillage: No amendments but deep (approximately 18 inches) cultivation

6. Control: no amendments and no cultivation

Sand has been included in the study design because of its potential for increasing soil porosity, which will increase soil infiltration and allow leaching of salts. In a study of experimental soil columns by Rahman et al. (1996), sand gave successful results and significant increase of water infiltration rate when compared with other amendments. 
All test plots receive an appropriate seed mix, transplanted seedlings, and a light mulch. Transplants will include both salt tolerant natives and exotic species (especially bermuda grass). Since we want to determine the success of seeding into the proposed soil treatments, seeding is not a treatment itself, in the experimental sense, but rather our result. We agree with the value of testing multiple seeding densities, and propose testing high density seeding as part of a planting study, described at the end of this report.

Replication, is of course, a necessary element to experimentation because it allows variation among samples to be determined and eliminates the possibility that a research result is merely a fluke. Three replicates is the minimum number with which one can calculate a measure of variation, such as variance or standard deviation. Such measures are necessary to determine significance of findings. It is extremely important that we "block" the planting sites by salt levels; i.e., test plots divided into three salinity categories, all treatments will be planted into each of the salinity categories, at the same time providing the minimum of three replicates. Since salt levels are mostly quite high, we selected salt categories within this range of values. Field operations at the Large Scar site are shown in Figures 15 through 17.

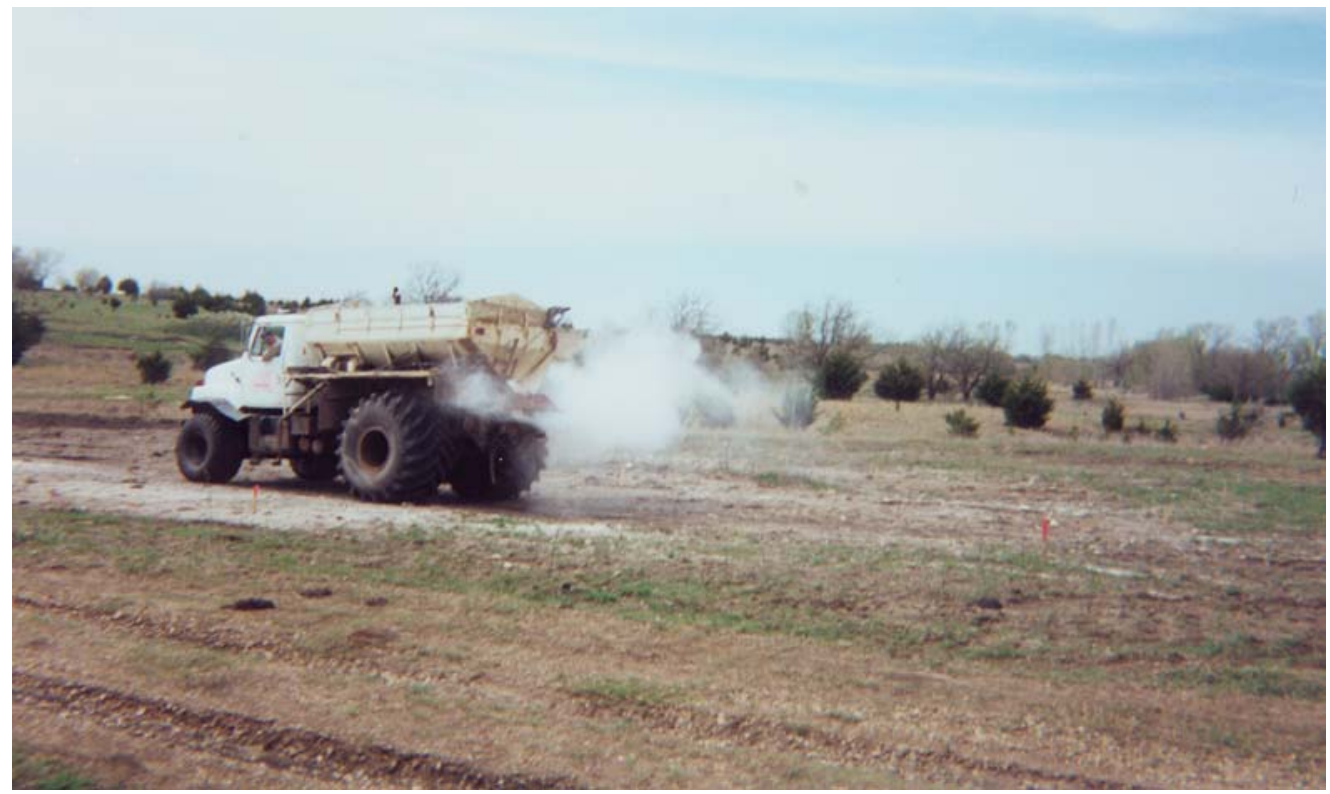

Figure 15: Spreading agricultural gypsum at the Large Scar at Leon Waterflood 


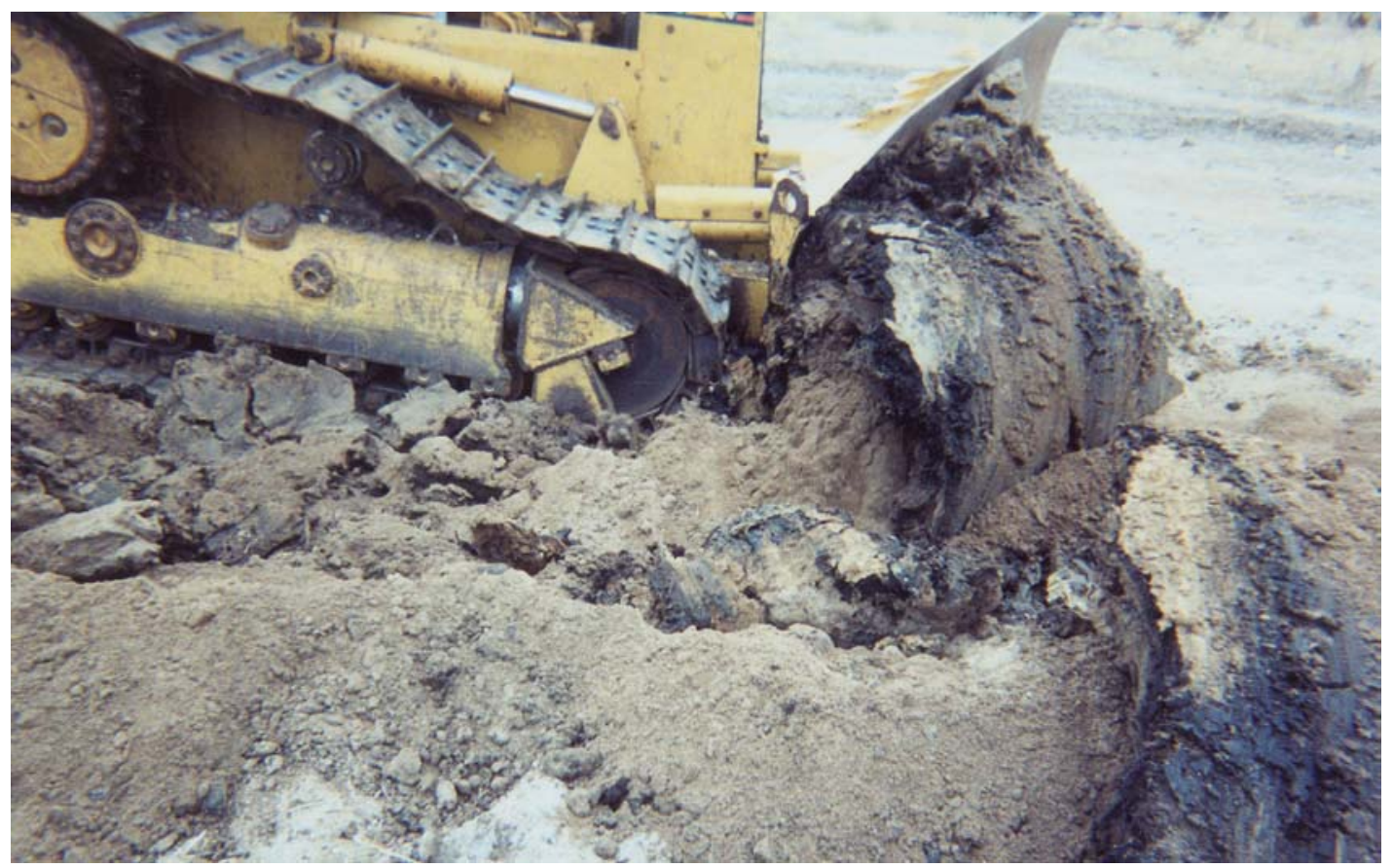

Figure 16: Deep tilling at an individual test-plot on the Large Scar

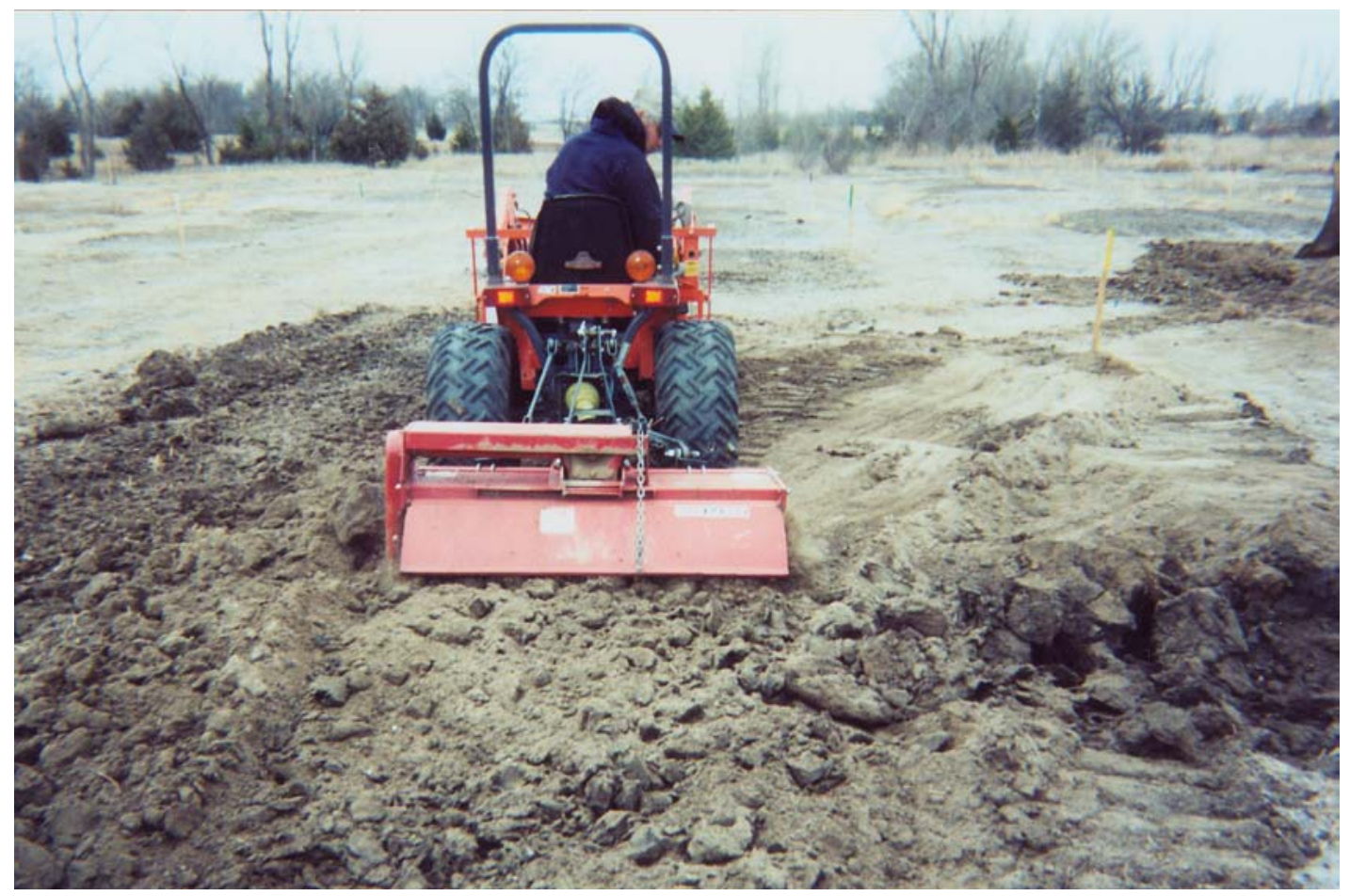

Figure 17: Shallow tilling at an individual test-plot on the Large Scar

\section{Irrigation}

Because of the importance of irrigation in reducing soil salts, we have included it in the experimental design described below as a treatment in its own regard. It is added into the design as the soil treatments are repeated: with irrigation, and without. Irrigation was accomplished with a drip system to deliver water directly to the selected test-plots. 
During the summer of 2002, the test-plots were watered four times for approximately four hours each time. Each watering episode allowed approximately 40 gallons of water to be released directly to each 5 -meter by 5 -meter square plot, equivalent to approximately 0.37 inches of water over each test-plot.

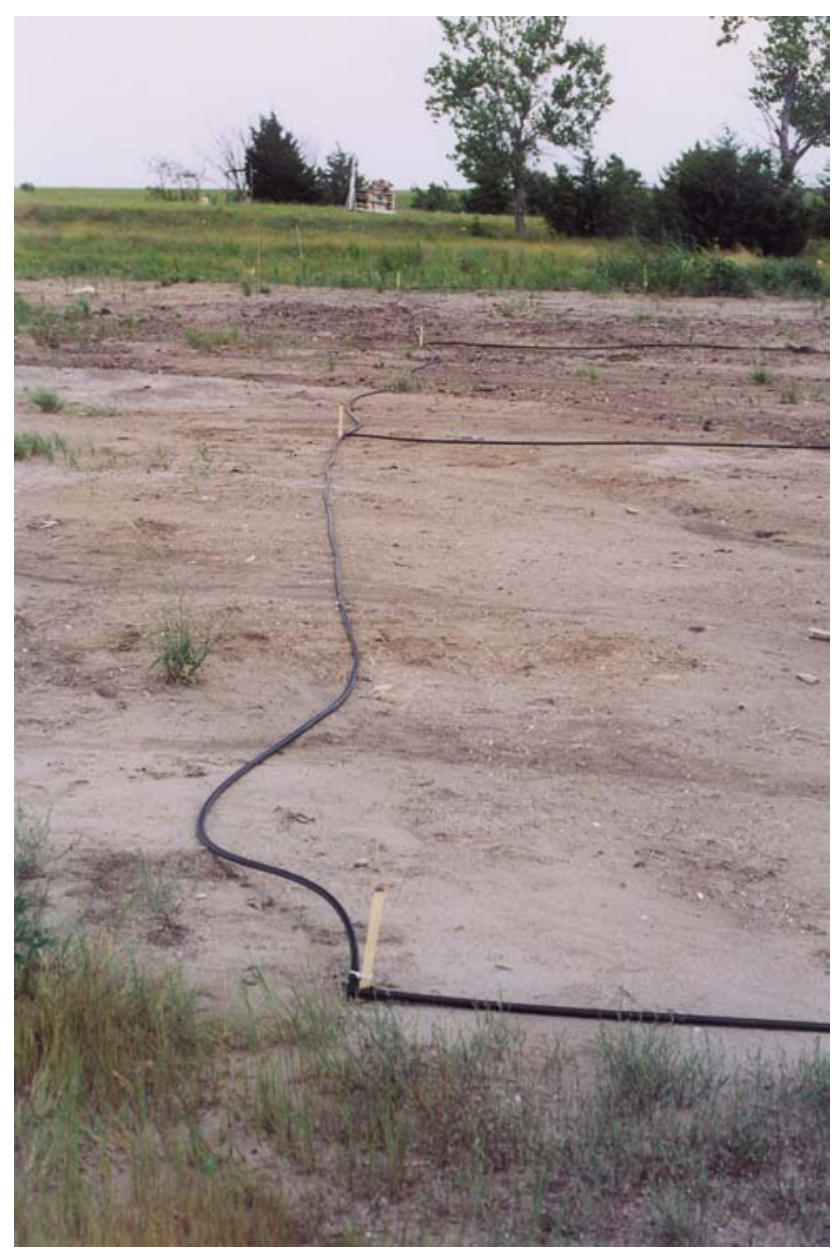

Figure 18: Irrigation system at the Large Scar

\section{Test-Plot Design}

The design as shown below in Figure 19, is a randomized complete block design, with three salinity levels as the blocks, and the six soil preparation methods as the treatments. Irrigation or precipitation provides a second level of treatment, but since irrigation cannot be randomly assigned, the entire design is repeated on the irrigated area. The total number of test plots, including controls, is 36 . The treatments are randomly assigned based on salt category. 
Figure 19: Experimental Layout for Large Scar-Leon Water Flood

\begin{tabular}{|c|c|c|c|c|c|c|}
\hline & A & B & $\mathrm{C}$ & $\mathrm{D}$ & E & $F$ \\
\hline & A-1 & B-1 & C-1 & D-1 & E-1 & F-1 \\
\hline 2 & A-2 & B-2 & C-2 & D-2 & E-2 & F-2 \\
\hline 3 & $\begin{array}{c}\text { A-3 } \\
\text { 6. Control }\end{array}$ & B-3 & C-3 & $\begin{array}{c}\text { D-3 } \\
\text { 3. Gypsum }\end{array}$ & E-3 & F-3 \\
\hline 4 & $\begin{array}{c}\text { A-4 } \\
\text { 1. Topsoil }\end{array}$ & B-4 & C-4 & $\begin{array}{c}\text { D-4 } \\
\text { 5. Tillage }\end{array}$ & $\begin{array}{c}\text { E-4 } \\
\text { 5. Tillage }\end{array}$ & \\
\hline 5 & $\begin{array}{c}\text { A-5 } \\
\text { 5. Tillage }\end{array}$ & $\begin{array}{c}\text { B-5 } \\
\text { 6. Control }\end{array}$ & $\begin{array}{l}\text { C-5 } \\
\text { 4. Sand }\end{array}$ & $\begin{array}{c}\text { D-5 } \\
\text { 1. Topsoil }\end{array}$ & E-5 & \\
\hline 6 & $\begin{array}{c}\text { A-6 } \\
\text { 5. Tillage }\end{array}$ & $\begin{array}{c}\text { B-6 } \\
\text { 4. Sand }\end{array}$ & $\begin{array}{c}\text { C-6 } \\
\text { 3. Gypsum }\end{array}$ & $\begin{array}{c}\text { D-6 } \\
\text { 6. Control }\end{array}$ & & \\
\hline 7 & $\begin{array}{c}\text { A-7 } \\
\text { 1. Topsoil }\end{array}$ & $\begin{array}{c}\text { B-7 } \\
\text { 1. Topsoil }\end{array}$ & $\begin{array}{c}\text { C-7 } \\
\text { 2. Manure }\end{array}$ & $\begin{array}{c}\text { D-7 } \\
\text { 3. Gypsum }\end{array}$ & $\begin{array}{l}\text { E-7 } \\
\text { 4. Sand }\end{array}$ & \\
\hline 8 & $\begin{array}{l}\text { A-8 } \\
\text { 6. Control } \\
\end{array}$ & $\begin{array}{r}\text { B-8 } \\
\text { 4. Sand } \\
\end{array}$ & $\begin{array}{c}\text { C-8 } \\
\text { 5. Tillage }\end{array}$ & $\begin{array}{c}\text { D-8 } \\
\text { 3. Gypsum } \\
\end{array}$ & $\begin{array}{c}\text { E-8 } \\
\text { 2. Manure }\end{array}$ & $\begin{array}{r}\text { F-8 } \\
\text { 6. Control } \\
\end{array}$ \\
\hline 9 & $\begin{array}{c}\text { A-9 } \\
\text { 2. Manure }\end{array}$ & $\begin{array}{c}\text { B-9 } \\
\text { 1. Topsoil }\end{array}$ & $\begin{array}{c}\text { C-9 } \\
\text { 3. Gypsum }\end{array}$ & $\begin{array}{c}\text { D-9 } \\
\text { 5. Tillage }\end{array}$ & $\begin{array}{c}\text { E-9 } \\
\text { 6. Control }\end{array}$ & $\begin{array}{c}\text { F-9 } \\
\text { 1. Topsoil }\end{array}$ \\
\hline 10 & $\begin{array}{l}\text { A-10 } \\
\text { 4. Sand }\end{array}$ & $\begin{array}{c}\text { B-10 } \\
\text { 2. Manure }\end{array}$ & $\begin{array}{c}\text { C-10 } \\
\text { 2. Manure }\end{array}$ & $\begin{array}{c}\text { D-10 } \\
\text { 3. Gypsum }\end{array}$ & $\begin{array}{c}\text { E-10 } \\
\text { 2. Manure }\end{array}$ & $\begin{array}{l}\text { F-10 } \\
\text { 4. Sand }\end{array}$ \\
\hline
\end{tabular}

Soil amendments and tillage was accomplished between $2 / 28 / 02$ and 3/03/02. At the completion of soil work, all the test-plots were planted with the following scheme:

- 15 seedlings of inland saltgrass (Distichlis)

- 5 seedlings of Sporobolus

- 5 seedlings of Poa arida

- $44 \mathrm{lbs} /$ acre of seed applied to each test-plot, consisting of an appropriate prairie grass mix:

○ Buffalograss

- Tall Wheatgrass 
○ Western wheatgrass

$\circ$ Squirreltail

- Fult's Alkaligrass

- Blue Gramma

- 16 sprigs of hybrid Bermuda per test-plot

In addition, a drip irrigation system was laid out to provide water to 18 of the 36 testplots in order to augment precipitation, which was expected to be below normal for the growing season. The irrigated test-plots were a duplicate of the non-irrigated plots.

\section{IMPOUNDMENT ON THE WEST SCAR}

During the winter of 2001 the impoundment was constructed over the deeply eroded gullies of the West scar. The extent of the gullying is shown in Figure 20.

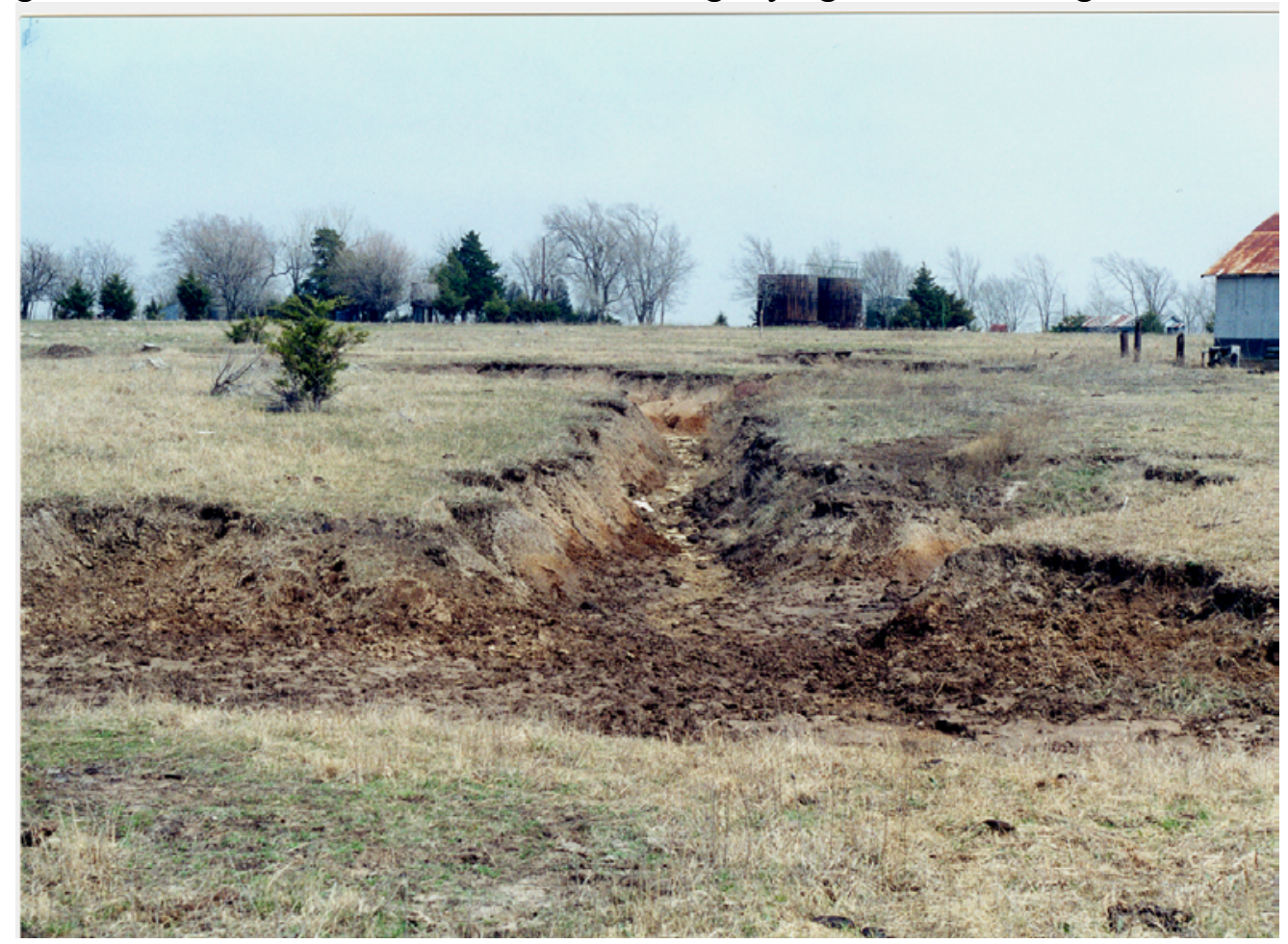

Figure 20: West Scar Gullying

The objective of this method was two fold: to research an alternative to soil amendments and monitor water quality changes downgradient of the West Scar. The design was supplied by the USDA - Natural Resources Conservation Service and is attached in the Appendix. The impoundment is expected to be approximately 8.0 feet deep, cover approximately 1.0 acre, and is designed to hold approximately $2.8 \mathrm{ac}-\mathrm{ft}$ of water when full. The finished impoundment is shown in Figure 21. The impoundment is not expected to express suspended material or saline water downstream but is expected to be a supplementary source of livestock water for the landowner. The sides of the dam and the embankment around the pond have been seeded with an appropriate prairie grass mix. Cost of the impoundment was approximately $\$ 8,175$ to achieve approximately 1.0 acres of remediation. The only other option would have been to fill in the gullies with 
imported fill and seed the area - a much more costly option. Costs for other impoundments will be different depending upon size and location.

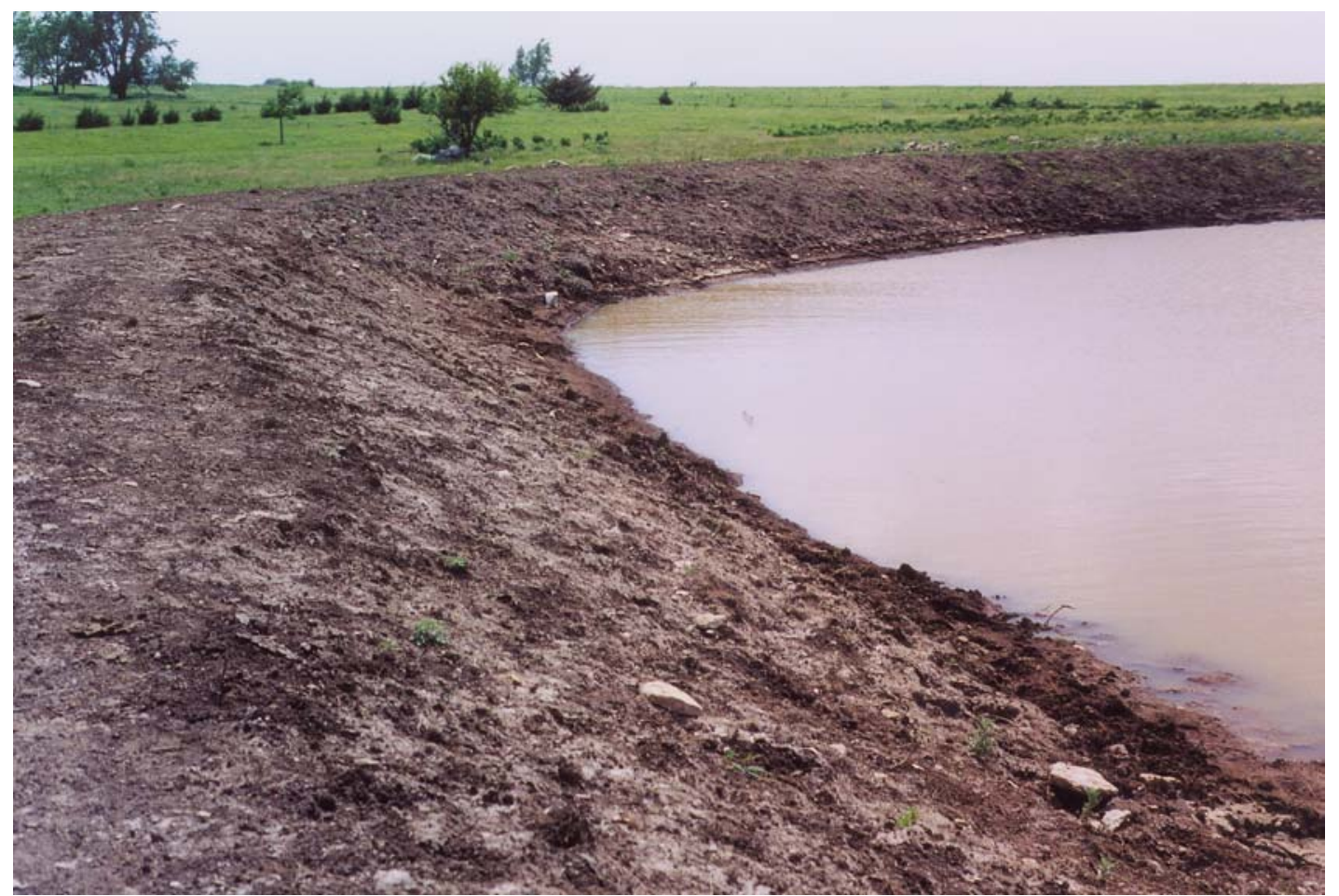

Figure 21: Impoundment constructed over the West Scar at the Leon Waterflood

\section{SOIL CHEMISTRY AT THE END OF THE SECOND GROWING SEASON}

Surface soil samples were retrieved at the end of the second growing season at both the Tank and Large Scars. The results of the lab work are detailed in the Appendix. The soil characterizations cannot, however, be closely compared with surface soil chemistry at the end of the first growing season because of remediation options. The in-situ soil was grossly amended by several methods to produce different growing conditions. For example, the six test-plots that received new topsoil had approximately six inches of lowsalinity soil applied to the surface and the new soil was then mixed into the top approximately 12 inches. The process was designed to achieve an approximately $50 \%$ mix within the root-zone but the actual mixing was highly variable.

\section{Soil Chemistry in Test-Plots Receiving Bulk Soil Amendments}

Salinity: Dilution of the saline soil was achieved with the addition of three materials topsoil, sand, and manure. Each material produced a reduction of salinity in the surface soil. Surface soil samples and lab results document the overall process with the six testplots that received new topsoil averaged $41 \%$ reduction in salinity while individual samples showed reductions as great as $90 \%$ and even an increase of $48 \%$. Similar dilution occurred within the manure and sand test-plots. The 18 test-plots that had dilution by way of soil amendments (topsoil, manure, and sand) are tabulated below in Table 1 . The 18 test-plots averaged $52.4 \%$ reduction in salinity after one growing season. This reflects essentially the process of dilution with a lesser degree of salinity reduction 
through leaching and for this reason, only the control plots were used to assess the reduction of salinity over the second year.

\begin{tabular}{|c|c|c|c|c|c|c|c|}
\hline \multirow{3}{*}{$\begin{array}{l}\text { Location } \\
\text { A-4 }\end{array}$} & \multicolumn{3}{|c|}{ TOPSOIL } & & & & \\
\hline & 2001 & 2002 & \%Reduct. & \multirow{2}{*}{\multicolumn{4}{|c|}{ MANURE }} \\
\hline & 9.2 & 2.7 & 70.6 & & & & \\
\hline$A-7$ & 5.3 & 2.63 & 50.4 & Location & 200 & 12002 & $\%$ Reduc \\
\hline C-5 & 10.1 & 4.32 & 57.22 & $A-9$ & 4. & 3.2 & 34.3 \\
\hline B-7 & 19.1 & 1.72 & 90.9 & B-10 & 6. & 5.1 & 22.2 \\
\hline B-9 & 8.1 & 1.66 & 79.5 & $\mathrm{E}-8$ & 24. & 7.64 & 68.8 \\
\hline F-9 & 18.5 & 28.2 & $47.6 \mathrm{inc}$ & $\mathrm{E}-10$ & 24. & 4.7 & 80.7 \\
\hline Average & 11.7 & 6.87 & 41.3 & C-7 & 11. & 5.7 & 52.4 \\
\hline Average & & & & $\mathrm{C}-10$ & 13. & 7.7 & 42.2 \\
\hline without $F-9$ & 10.4 & 2.6 & 75 & Average & 14. & 5.7 & 50 \\
\hline \multicolumn{4}{|c|}{ SAND } & & & & \\
\hline Location & 2001 & 2002 & $\%$ Reduc & & & & \\
\hline$A-10$ & 5.2 & 3.7 & 29.6 & & & & \\
\hline B-6 & 12.8 & 10.6 & 16.8 & \multicolumn{4}{|c|}{ TOTAL DILUTION } \\
\hline E-7 & 11.3 & 0.4 & 17.1 & Cells & 2001 & $2002 \%$ & Reduc \\
\hline C-5 & 17.3 & 6.5 & 62.7 & Average & & & \\
\hline $\mathrm{F}-10$ & 21.1 & 9.5 & 55 & of 18 & 12.7 & 6.1 & 52.4 \\
\hline B-8 & 5.6 & 3.2 & 42.8 & Average & & & \\
\hline Average & 12.2 & 5.6 & 55.7 & of 17 & 12.4 & 4.8 & 71.3 \\
\hline
\end{tabular}

Table 1: Summary of Surface Soil Salinity Before (2001) and After (2002) the Second Growing Season on the Test-Plots Where Dilution was Accomplished.

The dilution was effective in reducing soil salinity but whether or not leaching was augmented is unclear. If all 18 of the test-plots are considered, then the reduction in salinity was apparently restricted to the process of dilution since approximately $52 \%$ of the salinity was eliminated. But if the F-9 (added topsoil) sample is thrown out as a sampling aberration, then the remaining 17 test-plots reduced salinity by $75 \%$, strongly suggesting that leaching of salts was abetted by the dilution.

Sodicity: Sodicity is the measure of the relative amount of sodium in soil; it is frequently measured by the Exchangeable Sodium Percentage (ESP):

\section{ESP= Exchangeable sodium cations (meq/100 $\mathrm{g}$ soil)/Cation exchange capacity of soil (meq/100 g soil).}

ESP measures the portion of sodium in the soil that has adsorbed onto clay exchange sites within the clay mineral crystal lattice. ESP values over $15 \%$ indicate sodic, dispersed soils with generally impervious structures (API, 1997). Sodicity is remediated by replacing calcium or magnesium cations for the sodium on the clay lattice, usually accomplished by the application of gypsum (Ca, Mg SO4). In the Leon test-plots, surface soil sodicity was decreased by the addition of bulk amendments during the second growing season. The 17 samples from sites with added topsoil, manure, and sand show an average ESP of 15.7 , a reduction of approximately $25.4 \%$ during the second growing season. Several samples, however, show decreases of over $90 \%$ and several show increases as high as $300 \%$. The reduction of sodicity during the second season compares well with the first season when there was a $22 \%$ decrease in the average ESP 
value, due largely to the application of gypsum. Dilution alone should not lower ESP values but the mechanism by which the addition of bulk amendments lowers ESP apparently includes increased soil permeability and the subsequent promotion of leaching. Exchange of calcium and magnesium cations for sodium and the increased leaching of sodium out of the surface soil would reduce ESP.

\section{Soil Chemistry in Control Test-Plots}

Salinity: Figure 22 displays the changes in surface soil salinity as expressed only by the control test-plots. These five plots show a general reduction of surface soil salinity averaging 34\%; this value represents an improvement over the average reduction shown during the first growing season (7\% at the Large Scar and 34\% at the Tank Scar). Reduction was not uniform but was widespread. The average reduction for the control plots is close to the reduction rate shown by the Tank Scar (19.9\% reduction) during the second growing season. Those test-plots that were only tilled prior to the second growing season averaged 38\% reduction, mirroring the reduction in the control group. It is important that the salinity reduction continued this past year without the addition of more gypsum or other calcium sources. These reductions are significant but bringing some of the most impacted soils back to productivity will still take several years of leaching. 
Figure 22: Trends in Surface Salinity at the Large Scar

\begin{tabular}{|c|c|c|c|c|c|c|}
\hline & A & B & $\mathrm{C}$ & D & $\mathrm{E}$ & $\mathrm{F}$ \\
\hline 1 & A-1 & B-1 & C-1 & D-1 & E-1 & F-1 \\
\hline 2 & A-2 & B-2 & $\mathrm{C}-2$ & D-2 & E-2 & F-2 \\
\hline 3 & A-3 & B-3 & $\mathrm{C}-3$ & D-3 & E-3 & F-3 \\
\hline 4 & A-4 & B-4 & C-4 & D-4 & E-4 & \\
\hline 5 & A-5 & $\begin{array}{c}\text { B-5 } \\
22.2 \text { to } \\
19.8 \\
\end{array}$ & C-5 & D-5 & E-5 & \\
\hline 6 & A-6 & B-6 & C-6 & $\begin{array}{c}D-6 \\
\mathbf{1 4 . 5} \text { to } 9.1\end{array}$ & E-6 & \\
\hline 7 & A-7 & B-7 & & D-7 & E-7 & \\
\hline 8 & $\begin{array}{c}\mathrm{A}-8 \\
\mathbf{4 . 0} \text { to } 5.4\end{array}$ & B-8 & C-8 & D-8 & E-8 & $\begin{array}{c}F-8 \\
\mathbf{2 4 . 2} \text { to } 8.1\end{array}$ \\
\hline 9 & A-9 & B-9 & C-9 & D-9 & $\begin{array}{c}\text { E-9 } \\
8.6 \text { to } 6.0\end{array}$ & \\
\hline 10 & A-10 & B-10 & C-10 & D- & E-10 & F-10 \\
\hline
\end{tabular}

\section{Large Scar - Leon Water Flood End of Second Growing Season} Surface EC $\longleftarrow$ Direction of Apparent Surface Leaching

Sodicity: Surface soil sodicity increased by an average $61 \%$ in the control test-plots during the second season when the average ESP value went from $28.4 \%$ to $45.6 \%$. The increase in ESP is likely due to wicking of sodium from lower soil zones into the surface soil. 


\section{Soil Chemistry and Irrigation}

The entire test-plot set was divided into two identical sets - one set received irrigation, the other set did not. Following is a comparison of the responses of those 18 test-plots that received bulk amendments, nine of which received irrigation and nine of which did not.

Salinity and Sodicity: Chemistry of surface soils from the 18 test-plots with bulk amendments added can be examined in terms of irrigated and non-irrigated duplicates as shown in Table 2.

\begin{tabular}{lrrrrrr}
\multicolumn{7}{c}{ TOTAL IRRIGATED DILUTION TEST-PLOTS } \\
Location & 2001 EC & 2002 EC & \%red EC & 2001ESP & 2002ESP & \%redESP \\
A-7 & 5.3 & 2.63 & 9.3 & 0.5 & \\
A-9 & 4.9 & 3.22 & 7.1 & 2.8 & \\
B-6 & 12.8 & 10.64 & 26.2 & 29.3 & \\
B-7 & 19.1 & 1.72 & & 30.7 & 2.4 & \\
B-8 & 5.6 & 3.2 & & 13.6 & 9.2 & \\
C-5 & 17.3 & 6.46 & & 30.1 & 14.4 & \\
C-7 & 11.9 & 5.66 & & 25.2 & 9.8 & \\
D-5 & 10.1 & 4.32 & & 21.8 & 9.6 & \\
E-8 & 24.5 & 7.64 & & 4.7 & 14.1 & \\
Average & $\mathbf{1 2 . 4}$ & $\mathbf{5 . 0 5}$ & $\mathbf{5 9 . 3}$ & $\mathbf{1 8 . 7 4}$ & $\mathbf{1 0 . 2}$ & $\mathbf{4 5 . 4}$
\end{tabular}

TOTAL NON-IRRIGATED DILUTION TEST-PLOTS

Location $2001 \mathrm{EC} 2002 \mathrm{EC} \quad \%$ red EC 2001ESP 2002ESP \%redESP

$\begin{array}{lllll}\text { A-4 } & 9.2 & 2.7 & 24.4 & 1.6\end{array}$

A-10 $\quad 5.2 \quad 3.66$

$\begin{array}{lllll}\text { B-9 } & 8.1 & 1.66 & 16.8 & 1.8\end{array}$

$\begin{array}{lllll}\mathrm{B}-10 & 6.5 & 5.06 & 7.1 & 8.4\end{array}$

$\begin{array}{lllll}\mathrm{C}-10 & 13.4 & 7.74 & 28.1 & 21.9\end{array}$

$\begin{array}{lllll}\mathrm{E}-7 & 11.3 & 9.37 & 39.5 & 39.6\end{array}$

$\begin{array}{lrrrr}E-10 & 24.3 & 4.68 & 35 & 37.6\end{array}$

$\begin{array}{lllll}\text { F-9 } & 18.5 & 28.2 & 37.1 \text { na } & \\ \text { F-10 } & 21.1 & 9.51 & 28.6 & 63.6\end{array}$

$\begin{array}{lllllll}\text { Average } & 13.1 & 8.06 & 38.4 & 25.1 & 21.8 & 13.1\end{array}$

Table 2: Comparison of Irrigated and Non-irrigated Test-plots with Bulk Amendment Dilution.

Table 2 documents the effects of irrigation on the remediation of soils. EC was reduced at a greater rate from the irrigated soils by a margin of $59.3 \%$ to $38.4 \%$. Reduction of sodicity was also accelerated by the addition of water during periods of drought; the reduction was more than three times what was achieved without irrigation. The use of irrigation, at least the second growing season, was significant. 


\section{Soil Remediation Successes}

During the second season of the project, it became clear that some remediation techniques were more effective than others. On the other hand, it was also obvious that some techniques were significantly more expensive than others. The following Table 3 gathers the remediation statistics from the past season.

\begin{tabular}{|c|c|c|c|}
\hline \multirow{2}{*}{ Technique } & \multicolumn{2}{|c|}{ Effectiveness } & Cost per Acre \\
\cline { 2 - 3 } & Salinity & Sodicity & $\begin{array}{c}\text { (estimated } \\
\text { from test-plots) }\end{array}$ \\
\hline $\begin{array}{c}\text { Control (gypsum had } \\
\text { been applied } \\
\text { previously to all plots) }\end{array}$ & $\begin{array}{c}34 \% \text { reduction at Large } \\
\text { Scar, } 19.9 \% \text { at Tank } \\
\text { Scar }\end{array}$ & $\begin{array}{c}\text { Increased } 61 \% \text { at Large } \\
\text { Scar, increased } 31 \% \text { at Tank } \\
\text { Scar }\end{array}$ & $\$ 0$ \\
\hline Tillage & $38 \%$ reduction & $11 \%$ reduction & $\$ 1,000$ \\
\hline Addition of Topsoil & $75 \%$ reduction & $85 \%$ reduction & $\$ 33,000$ \\
\hline Addition of Sand & $56 \%$ reduction & $6 \%$ increase & $\$ 30,000$ \\
\hline Addition of Manure & $50 \%$ reduction & $12 \%$ decrease & $\$ 16,000$ \\
\hline Irrigation & $\begin{array}{c}54 \% \text { increase in rate of } \\
\text { reduction }\end{array}$ & $\begin{array}{c}247 \% \text { increase in rate of } \\
\text { reduction }\end{array}$ & $\$ 2,700$ \\
\hline
\end{tabular}

Table 3: Effectiveness and Cost Comparison of Remediation Techniques.

Table 3 compares the remediation efficiencies of the techniques tested in the research. Costs are extrapolated from actual costs of remediating the test-plots. These cost estimates should only be used for comparison; actual costs will be determined by the size of the scar being remediated. Since each technique was applied to only 990 sq.ft. of soil surface, the associated costs are extraordinarily high. Nonetheless, Table 3 is effective for comparing the ability to reduce brine impacts and comparing relative costs. For example, tillage is almost as effective as bulk dilution with manure but cost for the manure is almost 20 times greater. Irrigation, on the other hand, is very effective and in this case was very economical.

Bulk Soil Amendments: The largest reductions appear to be associated with the bulk soil amendments of topsoil, manure, and sand; these amendments were also the most expensive. Topsoil in particular was able to reduce salt parameters to a large extent. Local conditions will significantly affect these costs, however. If a nearby source of sand, manure, or topsoil were available, for example, the costs for that remediation option would be very low. In those situations, the use of bulk soil amendments should certainly be considered.

No Action (Control), Tillage and Irrigation: The least expensive option - no action or control - produced very poor results. This relationship is obvious; the reason that these scars are being addressed at this point in time is that nothing has been done for a long time and the scars have grown larger and become more sterile. On the other hand, tillage and especially irrigation appear to produce significant reductions in both salinity and 
sodicity at low per-acre costs. Indeed both tillage and irrigation should be included in every remediation plan because of their relative cost-benefit values. Irrigation costs were low at the Large Scar in part because a reliable source of water was immediately available. This is not always true and will affect irrigation methods and costs.

The results of the second season allowed comparison of the efficiency of various methods of soil remediation prior to planting with appropriate seeds and seedlings. The recommended hierarchy for remediation of heavily scarred soil appears to be the following:

1. Gypsum tilled into topsoil

2. Drip-irrigation installed

3. Deep tillage

Soils that are less heavily scarred can be planted immediately with the soil preparation listed above while scars with very high EC and ESP values should not be planted until soil character improves.

\section{RESULTS AND DISCUSSION}

\section{SURFACE WATER CHARACTER}

An assessment of surface water quality was chosen to gauge the relative effects to the watershed from conditions present on the Leon Site, and quantify the transport processes of salts and sediment in runoff associated with different experimental treatments. A small, intermittent creek beginning about 1.5 miles above the Leon Site passes through the salt scar areas before emptying into the Little Walnut River approximately 1.2 miles below the Leon Site. Nineteen sampling stations were established along the general flow of this creek, while an additional 22 stations were established elsewhere at various distances but still in close proximity to the study area as shown in the map on Figure 23. 


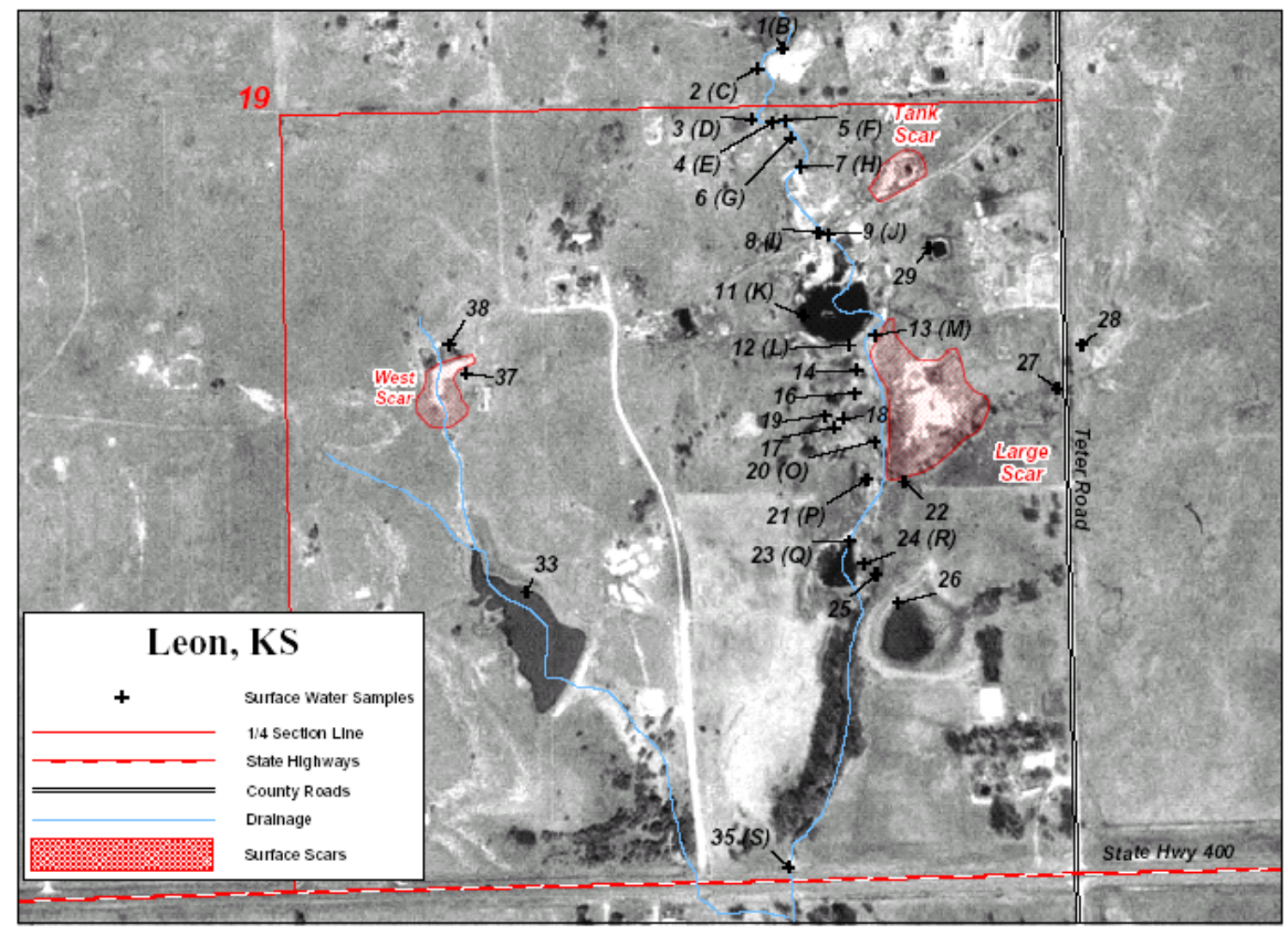

Figure 23: Digital Ortho Quad Map of Leon Project Site with Surface Water Sampling Sites

Each of the 41 sampling stations is identified numerically. In addition, the 19-station subset is cross-referenced alphabetically and sequentially from higher to lower portions of the small, un-named creek that passes through the study area. Water quality was examined five times in 2001 and eight times in 2002 across the study area to assess the impacts of the salt scars to surface waters. Seasonal variations in precipitation and unusually prolonged drought periods in both 2001 and 2002 caused many of the stations to dry up completely thus making sampling impossible at these times for certain locations. For each sampling event where water was available the parameters Specific Conductance, Dissolved Oxygen, $\mathrm{pH}$, Turbidity, Salinity, and Temperature were measured in situ using a Horiba U-10 water quality checker. The surface water quality data is collected in Appendix II at the end of this report. An evaluation of these parameters provides important information in oilfield impact assessment wherever watershed impacts are of potential concern.

Specific Conductance: Within the small watershed containing the study area the water quality parameter of most significance in assessing impacts from the salt scars is specific conductance (SC). Specific conductance (in microsiemens per centimeter $(\mu \mathrm{S} / \mathrm{cm})$ at $25^{\circ}$ C) is a standard field measure used to estimate overall salinity, and is proportional to the concentration of total dissolved solids including $\mathrm{Na}+, \mathrm{Ca}^{2+}, \mathrm{CO}_{3}{ }^{2-}$, as well as other ions. High SC indicates high dissolved solids concentration that can in turn affect the 
suitability of water for human consumption, irrigation, or other purposes. For reference, pure or distilled water has a very low SC, only a few $\mu \mathrm{S} / \mathrm{cm}$, whereas seawater averages about $50,000 \mathrm{mS} / \mathrm{cm}$ because of the large amount of dissolved salts it contains. Factors that affect SC are many and include the amount of surface water flow, the geology and soil type present, particular land use practices such as agriculture and industrial effluents, road salt, and drainage from oilfield production sites. Because of these variables surface waters in Kansas exhibit wide spatial and temporal ranges $(<100$ to $5000<\mu \mathrm{S} / \mathrm{cm})$ for SC both locally and across the state. For this reason we will limit most of the water quality discussion only to what was observed in the approximately 3-mile long watercourse under direct influence from the study site.

2001 vs. 2002 Mean Conductivity ( $\mu \mathrm{S} / \mathrm{cm})$ - Instream sites only

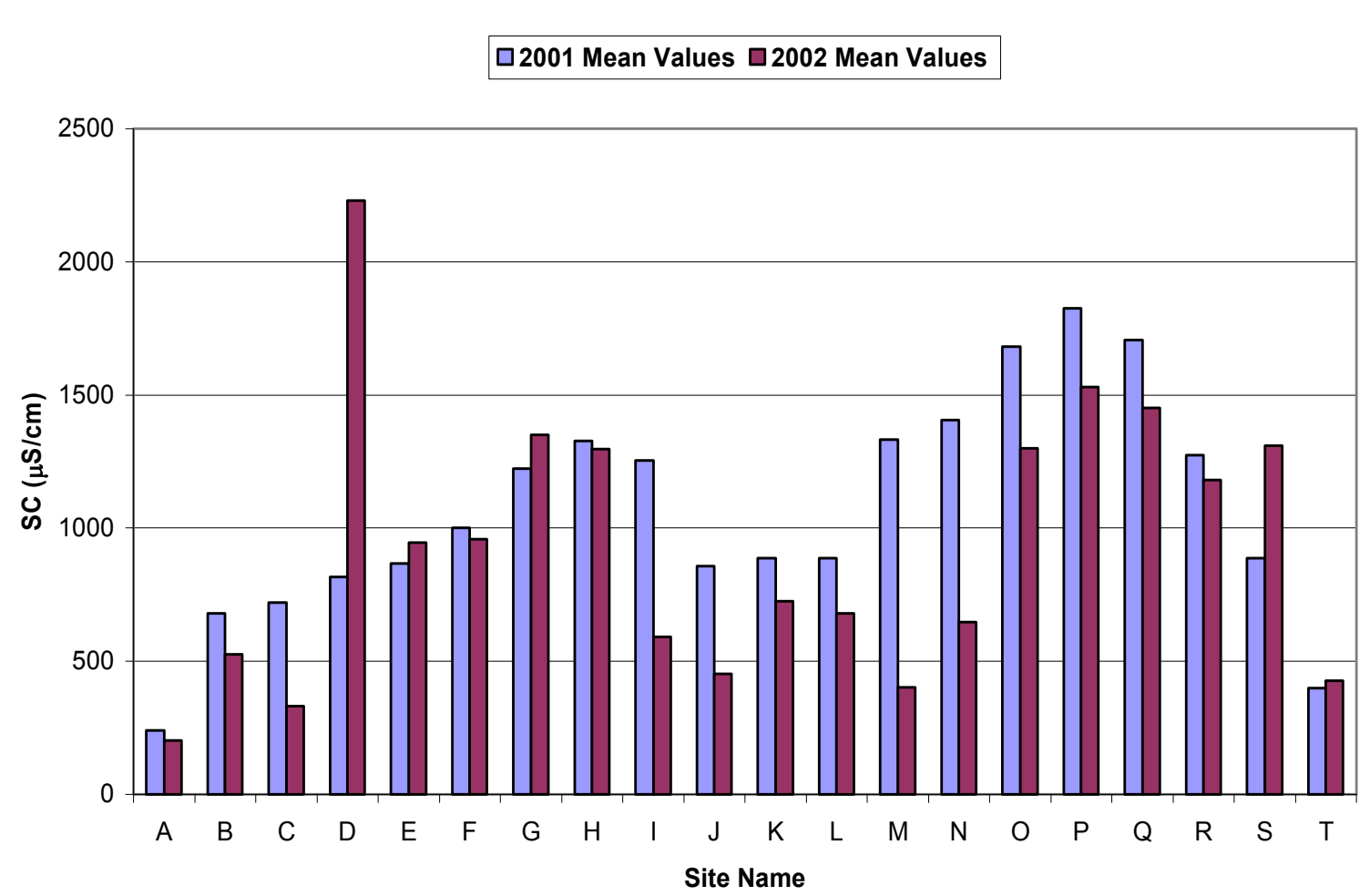

Figure 24: Specific Conductivity Comparison

Instream yearly data comparisons for SC are summarized in Figure 24; the sample sites are shown on the map in Figure 23. Site names (A through T) indicate sequential sampling points from uppermost to lowermost portions of the watershed along the small creek. Station A, located above any oilfield activity, was chosen as a benchmark control site. Moving downstream, the creek shows a gradual increase in $\mathrm{SC}$ as it approaches the Tank Scar (B-H). Higher SC than might be expected in the lower part of this reach is likely attributable to contributions from one or more additional oilfield sites situated just above the study area. Station I was located immediately downstream from the Tank Scar, but consistently showed lower $\mathrm{SC}$ values than several stations both upstream and downstream. This can be explained by the fact water is slightly impounded at this location and was thereby more diluted, yielding lower SC values. Stations J, K, and L 
were located in a small ( one acre) pond immediately downstream from the Tank Scar and similarly demonstrate the effects of dilution of the dissolved solids even though conductivities remain higher than water entering the scar areas. Stations $\mathrm{M}, \mathrm{N}, \mathrm{O}$ and $\mathrm{P}$ were adjacent to and running downstream from the Large Scar and show progressively elevated and increasing SC values attributable to impacts from the scar area, although it is believed Stations $\mathrm{M}, \mathrm{N}$, and $\mathrm{O}$ were the least impacted. Station $\mathrm{P}$ receives the brunt of runoff water from the Large Scar and these effects are obvious and continue downstream. Below the Large Scar SC values diminish slightly but remain persistently high through Stations Q, R, and S (approximately 0.3 mile below the Large Scar). Several stations $(14,16,17,18$, and 19) located west of and outside of the creek channel opposite to the Large Scar consistently yielded among the highest SC values recorded anywhere for aquatic environments on the site. One of these stations (16, a small pond) was more or less permanent while the others were more ephemeral in nature. Comparison of the instream stations to several others in the immediate area $(22,26,27,28,29,30,33)$ not influenced by the salt scars reveals low to moderate specific conductivity levels otherwise occur naturally in the area encompassed by the study area.

Mean SC values decreased for 15 of the 20 stations between 2001 and 2002. The apparent consistency of the data sets may suggest a small reduction in SC is occurring on the study area, either naturally or as a consequence of amendment activities of the current study, however the evidence for this is not conclusive. The severity of the prolonged drought created high natural variation in the data and this, coupled with the fact the scar areas represent only a small fraction of the larger watershed, provides little information useful for statistical analysis leading to inferences for the SC reductions that were observed.

What can be derived from the data is that water leaving the Leon Waterflood has considerably higher SC values than when it entered the area and intrusion from saltimpacted soil in the scar areas is the most evidenced explanation. The impact of the Leon salt scars on SC definitely contributes to water quality degradation in the small creek but is highly localized within the watershed becoming less significant upon dilution after entering the Little Walnut River. The construction of the small stock pond in the West Gully resulted in lower SC levels than formerly seen at that location by virtue of the relatively larger volume of water impounded, which is consistent with reduced conductivities found at other similar stations having impounded conditions.

Dissolved Oxygen: Dissolved Oxygen (DO) is an indicator of a water body's ability to support aquatic life. The amount of oxygen dissolved in water is expressed as a concentration, in milligrams per liter (mg/l) of water. Oxygen enters the water by absorption directly from the air or through photosynthesis by aquatic plants, and is removed from the water by respiration and decomposition of organic matter. The solubility of oxygen in any given water body is affected by other physical factors including temperature and total dissolved solids. In general, DO solubility decreases with increasing temperature and concentrations of total dissolved solids thus invoking several considerations pertinent to oilfield impacts and remediation. An increase in salt concentration due to inputs or evaporation may reduce the dissolved oxygen available to 
the aquatic ecosystem. During dry periods at the Leon site water levels decrease and the flow rate of the creek slows down. As the water moves slower it mixes less with the air and the DO concentration decreases. With summer sunlight warmer temperatures increase activity levels in plants and animals and depending on what organisms are present this may increase or decrease the DO concentration. Bare soil exposed by the salt scars causes an increase in erosion, which in turn can increase the amount of dissolved and suspended solids in the water. Petroleum-based organic wastes may also contribute to the biological oxygen demand of aquatic environments since decomposition of these compounds by aerobic bacteria remove oxygen from the water as they respire. Most fish and other aquatic organisms become stressed at DO concentrations less than about $4 \mathrm{mg} / \mathrm{l}$ and cannot survive at concentrations below about $3 \mathrm{mg} / \mathrm{l}$ of dissolved oxygen.

Critical oxygen minima $(<4 \mathrm{mg} / \mathrm{l})$ conditions with the potential for being harmful to aquatic life were found at certain times at several of the instream stations (A-S), particularly during the summer months. However, these conditions are thought to be more attributable to independent physical and biotic characteristics of the creek during the period of sampling than from primary influences of oilfield production. Many of the instream sites (D-I, M-Q) were located within a shallow and extensive cattail marsh and low oxygen levels recorded at these stations would therefore be expected of natural, boggy areas due to high biological oxygen demand (B.O.D.) from decomposition and other biological processes. Aquatic invertebrates and fish were observed in the creek and the ponds at various times providing some evidence dissolved oxygen concentrations were not low enough for extended periods to threaten the survival of aquatic life.

pH: The parameter $\mathrm{pH}$ is a measure of the acid/base $\left(\mathrm{H}^{+}\right.$to $\left.\mathrm{OH}^{-}\right)$conditions of a water body. The $\mathrm{pH}$ value is the exponent to the base 10 of the hydrogen ion concentration, and is expressed on a number scale of 1 to 14 with 7 being neutral. The $\mathrm{pH}$ value is lower as acidity increases, while the $\mathrm{pH}$ value increases as a solution becomes more basic. Each change in $\mathrm{pH}$ unit represents a tenfold change in acidity, thus a solution at $\mathrm{pH} 6$ is ten times more acidic than one at $\mathrm{pH} 7$. In south-central Kansas $\mathrm{pH}$ ranges of 6.5 to 9.0 are considered normal and fully supportive of fish life and aquatic invertebrates. Very high (greater than 10) or very low (less than 5) $\mathrm{pH}$ values may be harmful to aquatic organisms. One of the most significant environmental impacts of $\mathrm{pH}$ is the affect that it has on the solubility and thus the bioavailability of other substances. Changes in $\mathrm{pH}$ can also affect aquatic life indirectly by altering other aspects of water chemistry. For example, runoff from oilfield areas may contain a variety of volatile compounds and trace elements whose solubilities may be variously affected by changes in $\mathrm{pH}$. For the most part $\mathrm{pH}$ values recorded were well within normal ranges at all sampling stations for the duration of the study. Higher $\mathrm{pH}$ values recorded on several occasions in the middle pond stations (J, K, L) during summer 2002 were normal considering eutrophic (rich in dissolved nutrients) conditions in the pond had the effect of promoting intense algal growth and increased rates of photosynthesis, a process that consumes hydrogen ions and drives $\mathrm{pH}$ higher. The eutrophic conditions in the pond are not related to oilfield contamination, but rather to high nutrient loading due to the near-ubiquitous presence of cattle and fairly large numbers of waterfowl that tended to congregate here. 
Turbidity: Turbidity is a measure of the amount of light scattered in the water and is a function of the amount of fine particulate matter, usually tiny soil particles and microscopic algae, in suspension. The standard unit of measurement for turbidity is the NTU (nephalometric turbidity unit). Waters with high turbidity levels are obvious because of their cloudy or muddy appearance. Excessive turbidity levels can have adverse effects on aquatic organisms, such as reducing light penetration needed for photosynthesis by plants, interfering with the ability of fish and invertebrates to breathe, see, and feed, and by smothering benthic habitats as suspended particles settle to the bottom. Erosion and the resulting inputs of soil to aquatic systems increase turbidity and the rate of sediment deposition. Elevated rates of erosion of bare soil at oilfield sites with salt scars would be expected to raise turbidity levels in adjacent water bodies.

Owing to two important factors no meaningful trends could be established for the turbidity parameter. First, the infrequency of rain events resulting in significant runoff did not permit a fair assessment of the erosional impact on the small creek. Certainly more confounding to the turbidity data again were the activities of large numbers of cattle that had free access to many of the sampling stations and took free advantage of the situation.

Salinity: Like specific conductance, the salinity parameter is an alternative measure of dissolved inorganic solids in the water. There is a constant relationship between conductivity and salinity at certain temperatures. The salinity measurement is based on the principle of calculating the salt content, making use of the measured values of conductivity and temperature. Salinity values presented are expressed as a percent (\%), which can be used to derive an approximation of dissolved solids in parts per thousand (ppt).

Temperature: Temperature has a direct effect on the kinds of aquatic life that can live in a water body, and also influences water chemistry. The rate of chemical reactions generally increases at higher temperatures, which may in turn affect biological activity. Some compounds are also more toxic to aquatic life as they become more soluble at higher temperatures. The physical character of the stream and shoreline is an important consideration. A well-shaded shoreline reduces the impact of warming by the sun. The character of the watershed also affects temperature. If the watershed is forested and steep or hilly, runoff water will move quickly and the sun won't have much time to warm the runoff before it reaches the stream. The Leon Waterflood Site is located in a flat and relatively sparsely vegetated watershed. Here runoff water would be expected to move more slowly, with more time to absorb heat from the ground surface and from sunlight. The creek running through the site has little riparian cover other than cattails and widely scattered trees thereby exposing the stream to increased warming by sunlight. Water temperatures recorded were not unusual or unexpected given the character of the aquatic environments sampled.

\section{PLANT CENSUS AT THE END OF THE FIRST GROWING SEASON}

Summary: In the 2001 growing season vegetation establishment was poor and bare ground dominated the Leon Water Flood with values ranging from $61.6 \%$ to $94.8 \%$. Lack of vegetation was a result of excessive salt levels at the site. Electrical conductivity 
readings were above $14-16 \mathrm{mmhos} / \mathrm{cm}$. Salt-levels of this magnitude are toxic to even the most salt-tolerant plant species, and the maximum EC for non-salt-tolerant species is $4 \mathrm{mmhos} / \mathrm{cm}$. Seeding into the site had little effect because of the high salt levels, although some seeded species were present in trace amounts. Survival of transplanted salt-tolerant species was encouraging. Only when soil salinity levels are lowered to the range of plant tolerance, vegetation can be established and this vegetation will then further improve soil salinity levels by improving soil porosity, which will allow salt leaching.

Methods: Efforts to revegetate the Leon Water Flood included seeding of salt-tolerant and native species, and transplanting of salt-tolerant species into the two brine scars. Seeding and transplanting occurred in April 2001. Forty-six pounds of native seed were hand broadcast into the site. Seeded species included switchgrass (Panicum virgatum), big bluestem (Andropogon gerardii), little bluestem (Andropogon scoparius), Indian grass (Sorghastrum nutans), blue grama (Bouteloua gracilis), side-oats grama (Bouteloua curtipendula), western wheatgrass (Agropyron smithii), and buffalo grass (Buchloe dactyloides). A commercial wildflower mix was also broadcast into the site. Two species were transplanted into the Tank and Large Scars: 37 and 202 individuals of alkali sacaton (Sporobolus airoides), and 26 and 126 individuals of inland salt grass (Distichilis spicata), respectively.

In June and October the overall plant community and transplant survival were monitored. At the center of each square in the grid (see introduction), four 1.0-meter ${ }^{2}$ quadrats were sampled. All plant species within each quadrat were recorded, and their aerial percent cover was estimated using the techniques of Daubenmire (1959). The survival of all transplants was also recorded.

Plant Community Composition: Forty-four plant species occurred at the Tank Scar, and 47 species occurred at the Large Scar. A total of 47 species occurred at both sites (Appendix III). This relatively large number of species is typical of weedy sites. The most abundant species were weedy annual forbs, including broomweed (Gutierriza dracunculoides), buffalo burr (Solanum rostratum), flower-of-an-hour (Hibiscus trionum). Many plants appeared to be stunted or stressed. Most of the volunteer (or unplanted) species are temporal salt-avoiders. To cope with high salt levels, these species limit germination, growth, and reproduction to times of year when the highest salt levels can be avoided (i.e., cooler and wetter weather).

Bare ground continues to dominate both scars, with over $80 \%$ in most areas. Vegetative cover at the site is discouragingly low. At the Tank and Large Scars respectively, June plant cover was $11.9 \%$ and $5.0 \%$, and October cover was $38.2 \%$ and $15.1 \%$. More plant cover was established at the Tank Scar, most likely due to the lower salt levels in comparison to the Large Scar. The majority of vegetation at the sites occurs near the site perimeter, or on mounds or irregularities within the site, where soil salts are lower. The increase in cover between June and October does not indicate progress in revegetating the site, but rather indicates normal seasonal variation. Over the typical growing season individuals grow larger, and local native plant ecosystems are dominated by fall 
blooming vegetation. Native ecosystems, such as tallgrass prairie, typically exhibit much larger intra-annual increase in cover than was seen at the Leon Water Flood.

Seeded species

Transplanted Species

Volunteer Species

Vegetative Cover

Bare Ground

\begin{tabular}{cccc}
\multicolumn{2}{c}{ Tank Scar } & \multicolumn{2}{c}{ Large Scar } \\
\hline June & October & June & October \\
\hline $\mathbf{1 . 4} \%$ & $\mathbf{2 . 8} \%$ & $\mathbf{1 . 3 \%}$ & $\mathbf{1 . 8 \%}$ \\
$0.8 \%$ & $5.4 \%$ & $1.4 \%$ & $2.5 \%$ \\
$9.7 \%$ & $30.0 \%$ & $2.3 \%$ & $10.8 \%$ \\
& & & \\
$11.9 \%$ & $38.2 \%$ & $5.0 \%$ & $15.1 \%$ \\
$\mathbf{8 7 . 6 \%}$ & $61.6 \%$ & $94.8 \%$ & $84.6 \%$
\end{tabular}

Table 4: Percent cover of vegetation (seeded, transplanted, and volunteer) and bare ground at the Leon Water Flood large and tank scars in June and October 2001.

Effect of Seeding: Seeding of the Leon Water Flood had little effect on the plant community at the site, as indicated by the extremely low plant cover present (Table 4). It is interesting to note, however, that several seeded species were present in negligible or trace amounts: western wheat grass (Agropyron smithii), side-oats grama (Bouteloua curtipendula), and switchgrass (Panicum virgatum). Greater cover of all of these species is desirable at the Tank and Large Scars of the Leon Water Flood.

Saline soils disproportionately affect seed germination as opposed to survival of already established plants. For example, in one research study germination of salt-tolerant, tall wheatgrass seeds was $0.0 \%$ in soils with EC readings of $25 \mathrm{mmhos} / \mathrm{cm}$ (Conway 2000), and such levels are found within the Leon Water Flood. For this reason, additional seeding should not occur until EC readings throughout the site are below 14-16 $\mathrm{mmhos} / \mathrm{cm}$ (maximum range for salt tolerant species). Continued revegetation efforts should therefore focus on transplanting

Success of Transplants: Transplant survival in June 2001 was relatively high, then dropped considerably between June and October (Table 5). In the Tank Scar, survival of inland salt grass did not change during the growing season. Transplant survival is, nonetheless, encouraging. The high survival rates indicate that akali sacaton and inland salt grass are appropriate focus species for this remediation project. Both of these species are salt tolerant, are natives occurring in Kansas salt-affected grasslands, and are capable of clonal (vegetative) reproduction. The surviving transplants have not spread during the growing season. While it is normal for transplanted vegetation to grow very little in the first 1-2 years after transplanting, it also seems likely that the excessive soil salinity at the Leon Flood Water site may inhibit clonal growth of these transplants and contribute to further mortality. Although alkali sacaton and inland salt grass are among the most salt tolerant species that exist (whether native or not), they are limited by salt-levels with EC readings above 14-16 mmhos/cm, and such salt levels are present in much of the Leon Water Flood. 


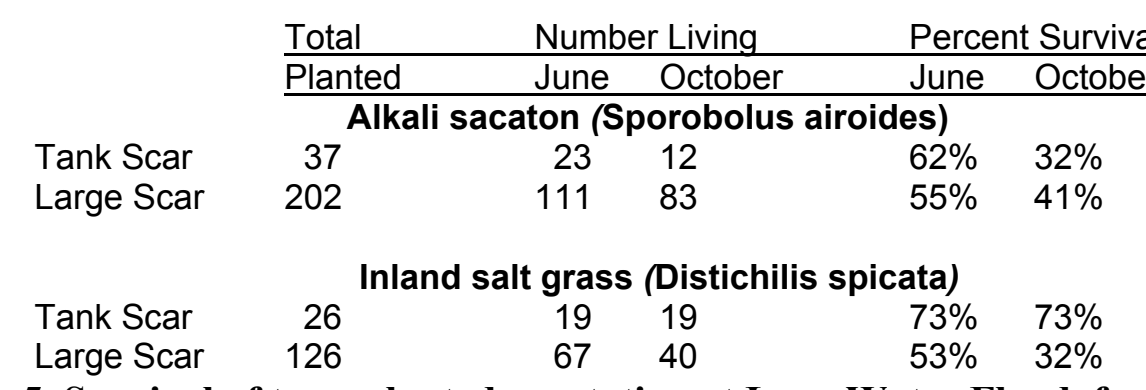

\section{Table 5. Survival of transplanted vegetation at Leon Water Flood, for June and October 2001.}

\section{PLANT CENSUS AT THE END OF THE SECOND GROWING SEASON}

Summary: Plant sampling in 2002 focused on the large scar at the Leon Water Flood, where the experimental treatments occurred. Bare ground continued to dominate the site, with values ranging from $27.6 \%$ to $93.0 \%$. Although cover by vegetation was higher in 2002 than in 2001, some parts of the site continued to have EC readings above 14-16 $\mathrm{mmhos} / \mathrm{cm}$, which was indicative of salinity levels which are too high to support even the most salt-tolerant plant species. Seeding into the site had relatively little effect, and most plant cover was produced by volunteer weeds or by transplanting halophytic grasses into the site. Native grasses fared best as transplants, with high survival rates of inland saltgrass $(86.7 \%)$, alkali sacaton $(84.0 \%)$, and arid bluegrass $(83.3 \%)$ at the end of the growing season. Of the six experimental treatments, the addition of topsoil produced the lowest EC readings and highest plant cover. However, the vegetation in the topsoil plots was primarily weeds that were introduced as seeds from the added topsoil. Plant results indicate that revegetation efforts should continue to focus on transplanting, and that the topsoil, manure, and sand treatments are most promising to improve site conditions.

Methods: In April 2002, the Large Scar at the Leon Water Flood was transplanted and seeded with salt-tolerant species. Each experimental plot was transplanted four species of native halophyte grass: fifteen seedlings of inland saltgrass (Distichlis spicata), five seedlings of alkali sacaton (Sporobolus airoides) and five seedlings of arid bluegrass (Poa arida). Additionally, each plot was planted with sixteen sprigs of root material from a hearty hybrid of bermuda grass (Cynodon dactylon; hybrid name,Tufkote). All transplants were planted in a regular pattern to allow relocation for sampling. Although revegetation efforts for 2002 focused upon tranplanting, several species of native and exotic halophyte grass were hand broadcast into the large scar. Species and seeding rates are listed in Table 6.

\begin{tabular}{lcc} 
Common Name & Ibs/acre & Nativity \\
\hline & 2 & \\
Blue Grama (Bouteloua gracilis) & 15 & Native \\
Buffalograss (Buchloe dactyloides) & 4 & Native \\
Fult's Alkaligrass (Puccinellia distans) & 8 & Exotic \\
Jose Tall Wheatgrass (Agropyron elongatum) & 7 & Exotic \\
Squirreltail (Elymus elymoides) & 8 & Native \\
Western wheatgrass (Agropyron smithii) & 8 & Native
\end{tabular}

Table 6. Species seeded at the Leon Water Flood 
In June and September 2002, the plant community and transplant survival within the experimental plots were monitored. All species present in each of the 36 experimental plots were determined. Aerial percent cover per plot of bare ground, broad leaf plants (forbs), and grasses and grass-like plants (graminoids) were estimated using a modified Daubenmire (1959) method. Cover by transplanted grasses was determined separately from other graminoids (i.e., volunteer and seeded graminoids). Transplants were relocated using measurements, and living transplants of each species were counted.

Plant Community Composition: Sixty-five plant species occurred in the experimental plots at the Large Scar, with sixty-five species present in June and thirty-four species present in September (Appendix III). Species were generally weedy annuals typical of disturbed areas and waste ground. The most abundant species were annual weeds, such as pigweed (Amaranthus rudis and Amaranthus graecizans), lamb's quarters

(Chenopodium berlanderi), and broomweeed (Gutierrizia dracunculoides). These were volunteer species that came to the site through wind dispersal or via the soil amendments. Native perennial grasses typical of tallgrass prairie were scarce at the Leon Water Flood. As in 2001, bare ground dominated the site with cover values ranging from $27.6 \%$ to 93.0\%.

The plant community differed among the six experimental treatments (Table 7). The highest vegetative cover occurred in the topsoil (82.4\% in June, $81.4 \%$ in September) and manure (36.6\% in June, $60.1 \%$ in September). In order to determine if differences in plant cover were greater than differences produced by random variation, cover for each of the treatments were tested statistically with an analysis of variance test (ANOVA). treatments. Cover by bare ground, forbs, and graminoids was significantly higher in the sand treatment, compared to the other five treatments, for June 2002 sampling. For September 2002, differences between sand and the other five treatments were not clear statistically, probably due to variation in the plant community that developed over the growing season. The higher plant cover observed in the topsoil treatment is probably a result of weed seeds, which were present in the topsoil amendment at the time of application. 
JUNE

Bare Ground

Forb Cover

Graminoid Cover

Transplant Cover

\begin{tabular}{rrrrrr} 
Control & Gypsum Manure Sand & \multicolumn{3}{c}{ Tillage } & Topsoil \\
\hline $\mathbf{8 0 . 3 \%}$ & $\mathbf{9 3 . 0 \%}$ & $\mathbf{6 3 . 4 \%}$ & $\mathbf{9 0 . 0 \%}$ & $\mathbf{9 3 . 4 \%}$ & $\mathbf{2 7 . 6 \%}$ \\
$\mathbf{1 3 . 2 \%}$ & $3.2 \%$ & $17.5 \%$ & $4.7 \%$ & $3.1 \%$ & $\mathbf{4 5 . 7 \%}$ \\
$5.3 \%$ & $2.3 \%$ & $16.4 \%$ & $3.8 \%$ & $2.5 \%$ & $25.5 \%$ \\
$1.2 \%$ & $1.5 \%$ & $2.6 \%$ & $1.5 \%$ & $1.0 \%$ & $1.3 \%$
\end{tabular}

SEPTEMBER

Bare Ground

Forb Cover

Graminoid Cover

Transplant Cover
Control Gypsum Manure Sand Tillage Topsoil

$\begin{array}{lllllll}\mathbf{5 2 . 5 \%} & \mathbf{7 4 . 1} \% & \mathbf{3 9 . 9} \% & \mathbf{5 5 . 7 \%} & \mathbf{5 3 . 0 \%} & \mathbf{2 8 . 6 \%}\end{array}$

$\begin{array}{lllllll}31.6 \% & 15.2 \% & 40.7 \% & 12.8 \% & 30.5 \% & 42.9 \%\end{array}$

$\begin{array}{llllll}12.3 \% & 8.5 \% & 14.9 \% & 25.6 \% & 13.8 \% & 25.1 \%\end{array}$

$3.7 \% \quad 2.1 \% \quad 4.5 \% \quad 5.8 \% \quad 2.7 \% \quad 3.4 \%$

Table 7. Percent cover of vegetation and bare ground at the Leon Water Flood large scar in June and September 2002, for each of six experimental treatments.

Effect of Seeding: All seeded species were present in the Leon Water Flood large scar, but comprised an extremely low percent cover relative to the overall plant community. This is due to the disproportionate effect of soil salinity on seed germination, as opposed to survival of seedlings or mature plants. Although efforts to revegetate brine scars should focus on transplanting, seeding may be useful because seeds can remain viable for many years. As soil salinity continues to improve, dormant seeds planted year before could germinate.

Success of Transplants: Transplant survival (Table 8) was relatively high in June, then generally dropped somewhat in September. Although overall survival was highest in the sand treatment, differences among the treatments were not statistically significant for survival of inland saltgrass, alkali sacaton, and arid bluegrass. Survival of Bermuda grass, however, was significantly higher in the sand treatment than the control treatment for June data only. Bermuda grass survival was much lower than the three native species, and this exotic species appears to offer no real advantage to native halophytes. Considering its poor survival and the risk of this species spreading outside of brine affected areas, it is not recommended for revegetation of salt affected sites in Kansas. Based on high survival of the other three transplanted species, they are highly recommended for future remediation sites. The high survival of native halophyte species is encouraging. Furthermore, transplanted species from 2001, especially inland salt grass, continued to spread rapidly suggesting that the transplants from the 2002 growing season will continue to positively influence the plant community of the Leon Water Flood large scar. 


\begin{tabular}{|c|c|c|c|c|}
\hline & Control Gypsum & Manure Sand & Tillage & Topsoil \\
\hline Distichilis spicata (Inland saltgrass) & $94.4 \% \quad 78.9 \%$ & $91.1 \% \quad 96.7 \%$ & $85.6 \%$ & $81.1 \%$ \\
\hline Sporobolus airoides (Alkali sacaton) & $86.7 \% \quad 90.0 \%$ & $86.7 \% 93.3 \%$ & $90.0 \%$ & $76.7 \%$ \\
\hline Poa arida (arid bluestem) & $86.7 \% \quad 76.7 \%$ & $66.7 \% \quad 86.7 \%$ & $66.7 \%$ & $46.7 \%$ \\
\hline Cynodon dactylon (bermudagrass) & $9.4 \% \quad 12.5 \%$ & $29.2 \% 53.1 \%$ & $15.6 \%$ & $46.9 \%$ \\
\hline Average & $59.3 \% \quad 54.1 \%$ & $63.4 \% \quad 78.0 \%$ & $56.5 \%$ & $63.0 \%$ \\
\hline
\end{tabular}

\section{SEPTEMBER}

Distichilis spicata (Inland saltgrass)

Sporobolus airoides (Alkali sacaton)

Poa arida (arid bluestem)

Cynodon dactylon (bermudagrass)

\begin{tabular}{ccccccc}
\multicolumn{2}{c}{ Control Gypsum } & Manure Sand & Tillage & Topsoil \\
\hline $67.8 \%$ & $86.7 \%$ & $67.8 \%$ & $85.6 \%$ & $67.8 \%$ & $64.4 \%$ \\
$76.0 \%$ & $66.7 \%$ & $84.0 \%$ & $76.7 \%$ & $72.0 \%$ & $64.0 \%$ \\
$73.3 \%$ & $83.3 \%$ & $73.3 \%$ & $80.0 \%$ & $63.3 \%$ & $66.7 \%$ \\
$23.4 \%$ & $14.6 \%$ & $25.0 \%$ & $51.0 \%$ & $40.6 \%$ & $26.0 \%$ \\
& & & & & \\
$47.6 \%$ & $55.7 \%$ & $52.0 \%$ & $70.3 \%$ & $50.4 \%$ & $48.4 \%$
\end{tabular}

Average

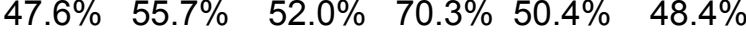

Table 8: Survival of four species of salt tolerant transplants in June and September of 2002, for each of six experimental treatments.

\section{SALINITY ANALYSES OF PLANT TISSUE}

Inland salt grass (Distichlis spicata) was an ideal target for testing the salt content of its tissue, since it flourished in the Leon Water Flood remediation, is highly recommended for remediation of brine scars in Kansas, and is native to Kansas prairie plant communities. The goal of testing plant tissues for salt content was to determine the extent of the plants' uptake of salt. Samples of inland saltgrass were collected in November 2002, from multiple plots with a range of three EC levels-low, medium, and high. Each $500 \mathrm{~g}$ sample was dried and ground prior to digesting the tissue with nitric and perchloric acid.

Sodium content of inland salt grass ranged from $3573 \mathrm{ppm}$ to $7250 \mathrm{ppm}$ (mean $=5212$ ppm), or roughly $0.3 \%$ to $0.7 \%$ (mean $=0.5 \%$ ) of the plant weight. Sodium content of the plant tissues was not related to levels of salts in the soil, as indicated by the lack of a positive correlation between sodium content and soil EC (Table 9). This lack of a relationship indicates that inland salt grass does not increase its salt uptake with increasing soil salinity levels. The large range of salt uptake (a 2 to 1 difference in the highest and lowest values) is indicative of the mechanism by which Distichlis spicata processes soil salts. Inland salt grass is part of a group of plants called salt eliminators, whereby a plant copes with excess salts by incorporating salts via the roots then exuding altered salt compounds through glands, or by excreting of salts at shoot surfaces. The salt compounds can be released into the atmosphere as methyl chloride. Another way that inland salt grass releases salts is through death and shedding of older leaves that have accumulated significant amounts of salt. At different times the plant's salt content may vary, depending on the cycle of accumulation and shedding. In brine scars where inland salt grass is well established and abundant, additional salts could be removed by harvesting plant tissues mechanically or by livestock grazing. 


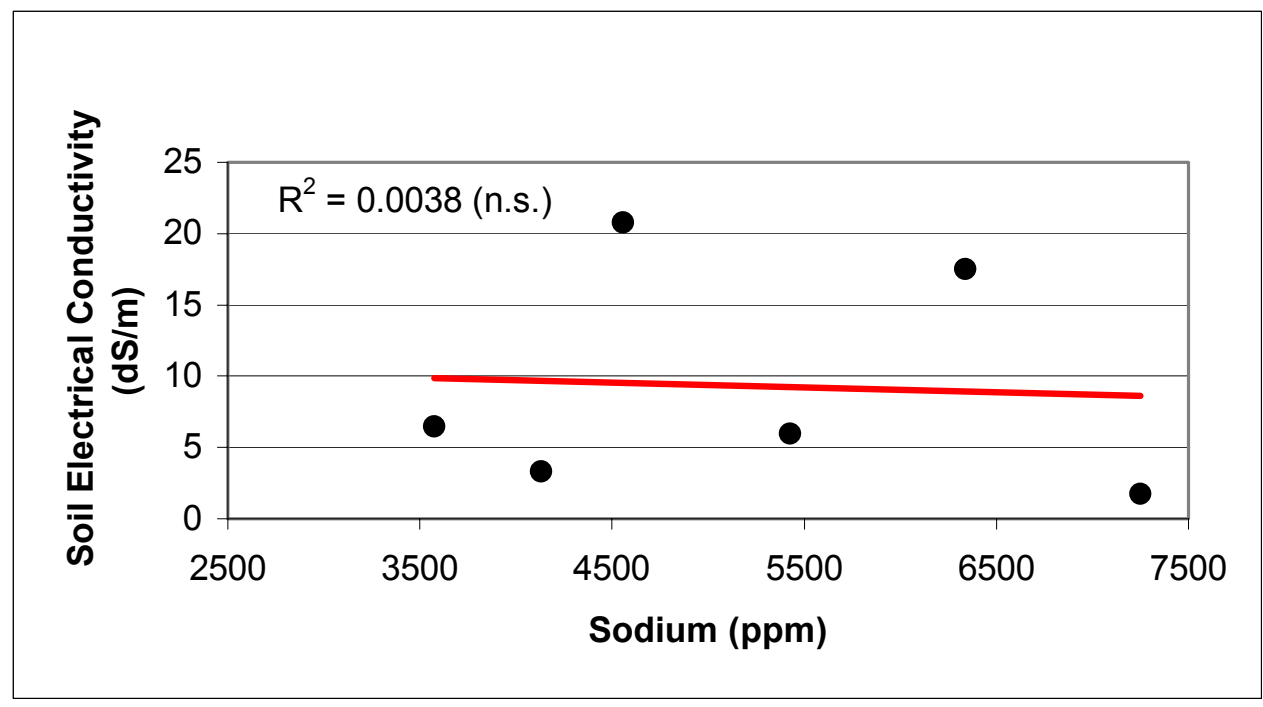

Table 9: Sodium content of inland saltgrass tissues vs. the electrical conductivity of soils at the Leon Water Flood.

Although sodium content and EC are not correlated with one another as is documented in Table 9 , the sodium content of inland salt grass varies from $0.3 \%$ to $0.7 \%$ of the plant's total weight.

\section{REVEGETATION RECOMMENDATIONS}

Revegetation can proceed through seeding, transplanted materials, or both. Native Kansas plant materials are preferred in most situations. Although some exotic species have been bred for extreme salt tolerance, they may become invasive. Most exotic grasses require fertilizer, whereas native grasses are more adapted to Kansas climate and soil conditions. Furthermore, this pilot study found that survival and spread of native materials was superior to exotic species. Only if the surrounding vegetation is exotic or improved grass should exotic plants be considered for remediation. When surrounding vegetation is native, planting native materials is highly recommended. The selection of seeding or transplanting should be based on site conditions, availability, and funding.

- Planting seeds is the most cost-effective but least successful way to introduce plants to a salt scar site. Because seeds are disproportionately sensitive to salinity, germination will be poor in all but the lowest salt concentrations. Seeds may, however, remain viable in the soil for several years.

- Sprigging or transplanting, in which live propagules or root-stock are planted into the site, is far more successful but can be expensive. In cases where vegetation must be established quickly, transplanting is most likely to achieve results.

Transplants are more tolerant of soil salinity than are seeds; highly saline soils may, however, result in low transplant success. When possible, both transplanting and seeding a remediation site provides the widest range of opportunities for successful revegetation. 
Revegetation efforts will be most effective when soil salinity has been reduced somewhat, to an EC range of 10-14 $\mathrm{mmhos} / \mathrm{cm}$. In this range, transplanted salt-tolerant vegetation is likely to survive and spread with time. After EC readings have been lowered to 4-6 mmhos/cm, seeding will be most effective. Thus we recommend transplanting in medium to high salinity sites (but not where brine impacts are very high), and seeding in low impact sites. Species recommended for transplanting and seeding are listed below in Table 10. If the site is tilled for agriculture, salt tolerant barley or alfalfa is recommended.

\begin{tabular}{llll} 
COMMON NAME & SCIENTIFIC NAME & NATIVITY & PROPAGULE TYPE \\
\hline Alkali Sacaton & Sporobolus airoides & Native & seed, transplant \\
Blue grama & Bouteloua gracilis & Native & seed \\
Buffalograss & Buchloe dactyloides & Native & seed \\
Inland Saltgrass & Distichylis spicata & Native & transplant \\
Squirreltail & Elymus elymoides & Native & seed \\
Tall Wheatgrass & Agropyron elongafum & Exotic & seed \\
Western Wheatgrass & Agropyron smithii & Native & seed
\end{tabular}

Table 10: Species recommended for brine scar remediation in Kansas

\section{CONCLUSIONS AND RECOMMENDED REMEDIATION PROCEEDURES}

Produced salt water can impact surface soil through a build-up of excess salinity and sodium. In order to return the soil to productivity and provide sufficient groundcover, both conditions must be remediated; sufficient salt must be removed so that plants can grow and excess sodium must be leached out to improve soil structure and permeability.

\section{Conclusions}

Salt scars took time to develop and take time to remediate. The research just completed at the Leon Waterflood demonstrated that remediation can succeed at various rates and various costs. Techniques need to be matched to specific conditions at the scar and the need for a timely resolution; local conditions will require either a wholesale replacement of large volumes of topsoil at great expense or a more gradual approach that will require several growing seasons. The research has shown that remediation of salt scars is best approached on the basis of severity of impact as indicated by surface soil salinity. In Kansas, and throughout the Mid-Continent, produced water will be dominated by sodium-chloride; during remediation, sodium will need to be replaced by calcium and magnesium cations. The process of ion replacement will take place at the same time that most of the total salts are leached out of the surface soil into deeper soil and bedrock strata. Replacement of sodium for other cations will also increase soil permeability, allowing more efficient leaching. Recommended remediation will depend upon the initial soil chemistry as determined by sampling of the surface soil.

\section{Soil Characterization}

Surface soil should be sampled across the scarred area, with sufficient samples to characterize the range of soil impact. For example, those areas denuded of vegetation should be sampled as well as those where sparse vegetation exists, in this way an accurate 
picture of salt water impact can be mapped and soil amendments can be calculated and scheduled. In Kansas, soil samples can be quickly and economically analyzed by the KSU Soil Lab, 2308 Throckmorton Hall, Manhattan, Kansas 66506. Similar labs exist in other states across the country. The KSU Soil Lab will run the "Salt Alkali Analysis" for $\$ 12.50$ per sample and report $\mathrm{pH}$, Soluble sodium, Extractible sodium, Exchangeable sodium, Estimated Cation Exchange Capacity, Exchangeable sodium percent (ESP), EC, Alkali Ranking, and Salinity Ranking. Of immediate importance is the EC data; these data can be used to derive a map of the salt scarring to determine the extent of impact to soils.

\section{Soil Remediation}

Surface soil salinity will drive the remediation process since mild impacts can be handled differently from more severely impacted scars. Following are the options recommended for impacted soils:

\begin{tabular}{ccccc}
$\begin{array}{c}\text { Impact } \\
\text { Rank } \\
\text { Mild }\end{array}$ & $\begin{array}{c}\text { Soil EC } \\
(\mathbf{m S} / \mathbf{c m})\end{array}$ & \multicolumn{1}{c}{ Soil Amendments } & Irrigation & Planting \\
Up to 4.0 & Gypsum and tillage & If needed & $\begin{array}{l}\text { Seeds, } \\
\text { transplants }\end{array}$ \\
$\begin{array}{c}\text { Medium } \\
\text { Severe }\end{array}$ & $\begin{array}{l}\text { O.0 to } 16.0 \\
\text { Over } 16.0\end{array}$ & $\begin{array}{l}\text { Gypsum and tillage } \\
\text { Gypsum and tillage annually }\end{array}$ & $\begin{array}{c}\text { Yes } \\
\text { Yes }\end{array}$ & $\begin{array}{l}\text { Transplants } \\
\text { None the } \\
\text { first year }\end{array}$
\end{tabular}

Mild impacts are those with slightly elevated salinities. In the area of Leon, native surface soils are in the range of 1.0 to $2.0 \mathrm{mS} / \mathrm{cm}$. In other parts of the state and surrounding states, soils could be more saline. Soils below 4.0 will support the robust growth of virtually any crop or groundcover (Donahue, et al, 1983).

Medium impacts are those that reduce the plant productivity of the soils but the actual reduction of yield will depend upon the species and varieties of plants to be grown. Crops such as alfalfa are more sensitive to salinity than some types of barley but most common plants will begin to show reduced yields in the range of 4.0 to $16.0 \mathrm{mS} / \mathrm{cm}$ (Donahue et al, 1983). Salt tolerant plants (halophytes) are able to show good vigor throughout this range. Soils within this range have responded well to remediation if soil permeability is established and sufficient water is available.

Severe impacts are those above an EC of $16.0 \mathrm{mS} / \mathrm{cm}$. Plants grown in these soils will show greatly decreased vigor, even halophytes (Donahue et al, 1983). Few if any seeds will sprout in these soils. It is normal for these soils to also exhibit signs of very high sodicity as well. It is most important that the remediation brings sufficient quantities of water to the scars and that the soil be worked often enough to supply permeability. Gypsum may need to be introduced in multiple batches to avoid over concentration of soluble material. Plants need not be added until EC levels drop below 16.0. 


\section{Specification of Soil Amendments}

The most common amendment to be added to salt-impacted soil is gypsum as a source of calcium and magnesium cations. Although there are other sources of these cations, agricultural gypsum is the cheapest and easiest to apply. As it is delivered to the site, agricultural gypsum consists of a range of grain sizes from powder to small chunks; this allows the gypsum to dissolve over an extended time period. The volume of gypsum $t$ be applied to the surface soil must be sufficient to displace the sodium on the clay minerals; gypsum volume must be calculated from the surface soil chemical analyses. The analyses derived by the soils lab referred to above can be used to calculate the amount of gypsum to be applied per acre using the following formula (Carty et al, 1997):

\section{Gypsum requirement $=(\mathrm{ESP}-5.0) \times(\mathrm{CEC}) \times(0.00078)=\mathrm{lbs}$ of gypsum $/ \mathrm{sq} \mathrm{ft}$ $\mathrm{ESP}=$ Exchangeable sodium percent as percent $\mathrm{CEC}=$ Cation Exchange Capacity as meq/100 g of soil}

\section{Example: Large Scar sample with $\mathrm{ESP}=13.1 \%, \mathrm{CEC}=21$}

$(13.1-5.0) \times(21) \times(0.00078)=$ lbs of gypsum per sq ft $(8.1) \times 21 \times(0.00078)=0.13 \mathrm{lbs} / \mathrm{sq} \mathrm{ft}=5,780 \mathrm{lbs} / \mathrm{ac}$

The above example would be appropriate for computing the amount of agricultural gypsum required to till into the upper one foot of soil. If the gypsum was to be tilled into the top 24" of soil, the number of $1 \mathrm{bs} / \mathrm{ac}$ will be doubled.

\section{Revegetation Recommendations}

Revegetation is recommended in two steps - transplants of growing plants and seeding. Transplants of salt-tolerant species can begin even while soil remediation is in progress. The recommended species include Distichilis spicata (Inland saltgrass), Sporobolus airoides (Alkali sacaton), Poa arida (arid bluestem), and Cynodon dactylon (Bermuda grass hybrid Tufkote ${ }^{\mathrm{TM}}$ or similar). Transplantable plants can be ordered from commercial nurseries, depending upon surface soil chemistry, plants should only be introduced after the remediation has brought soil to within the limits appropriate for the chosen varieties.

Seeds can be broadcast at any time but will likely not sprout until soil salinity levels have been reduced significantly. Seeds recommended for similar Kansas locations include switchgrass (Panicum virgatum), big bluestem (Andropogon gerardii), little bluestem (Andropogon scoparius), Indian grass (Sorghastrum nutans), blue grama (Bouteloua gracilis), side-oats grama (Bouteloua curtipendula), western wheatgrass (Agropyron smithii), and buffalo grass (Buchloe dactyloides). Owners or operators of scars at other locations in Kansas or adjacent states can inquire at local offices of the Natural Resource Conservation Service for recommended seed species. Costs for vegetation can vary considerably depending upon the availability of plants. 


\section{Irrigation Recommendations}

In parts of Kansas, rainfall is quite sparse even in the average years. As can be seen below in Figure 25, the Leon area averages approximately 32 inches of total precipitation per year while other areas gather more than 40 inches and less than 20 inches per year. In drought years, of course, precipitation is less and the need for irrigation is more.

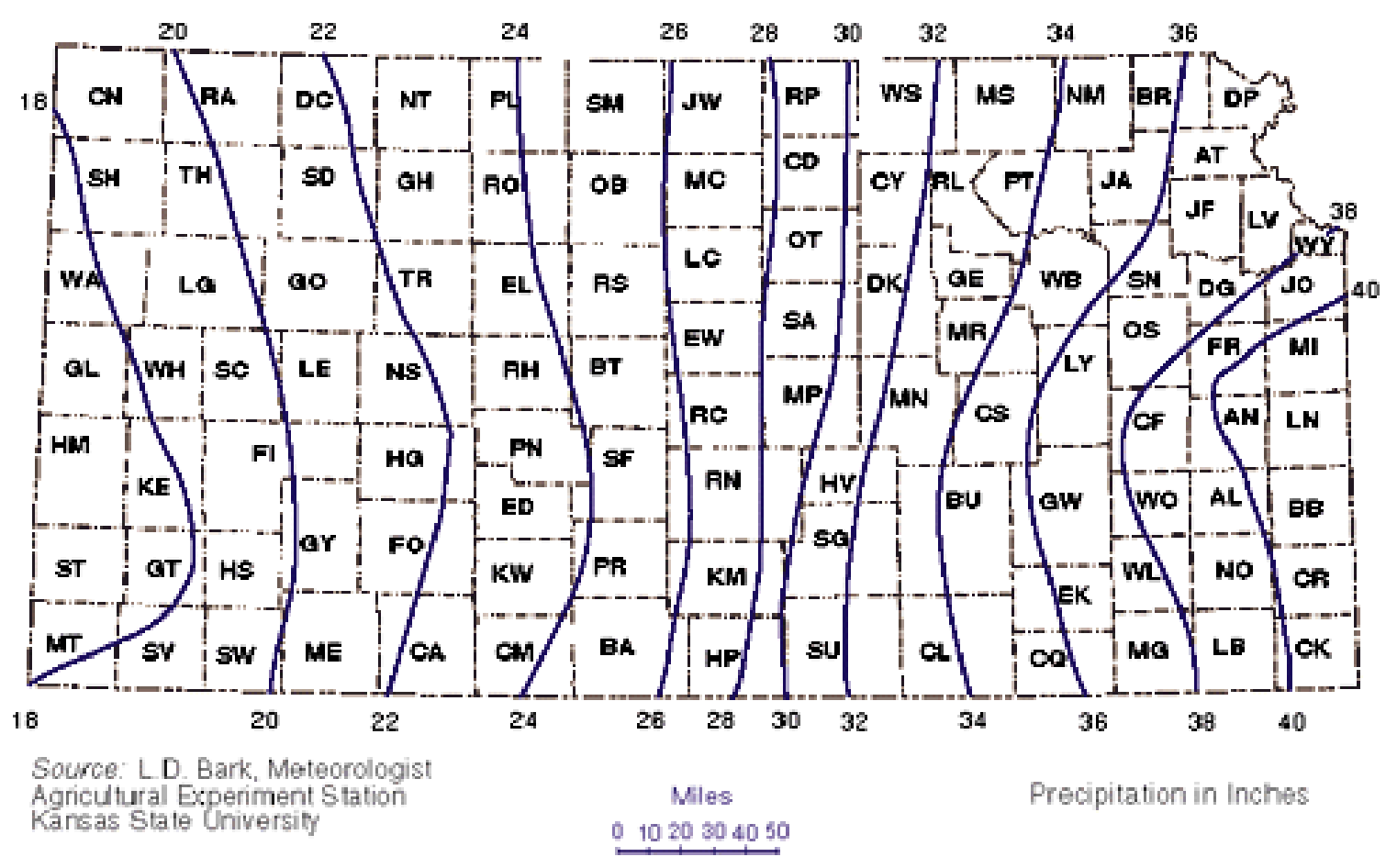

Figure 25: Average Annual Precipitation Across the State of Kansas.

The Leon site has received less than normal precipitation for the past several years and it was anticipated that the drought might continue through 2002 . The yearly summary of precipitation (Figure 26) for Wichita, approximately 30 miles from the Leon site, shows dry conditions in the early part of 2002 . For this reason, drip-irrigation was installed at the Large Scar on one-half of the test-plots. The test-plots were split in half so that one complete set was left un-irrigated while a duplicate set was irrigated. As the summer developed, however, less extra water appeared to be needed and only 1.6 inches of water was applied across the irrigated test-plots. This amount of moisture was enough to raise the actual observed precipitation line shown in Figure 26, above the average normal. More water could have been added since the soil scar is largely located on a sloping bedrock surface that drains west to the stream valley. This local condition will be different for each remediation project and could limit the amount of irrigation that would be optimal for leaching and plant growth. 

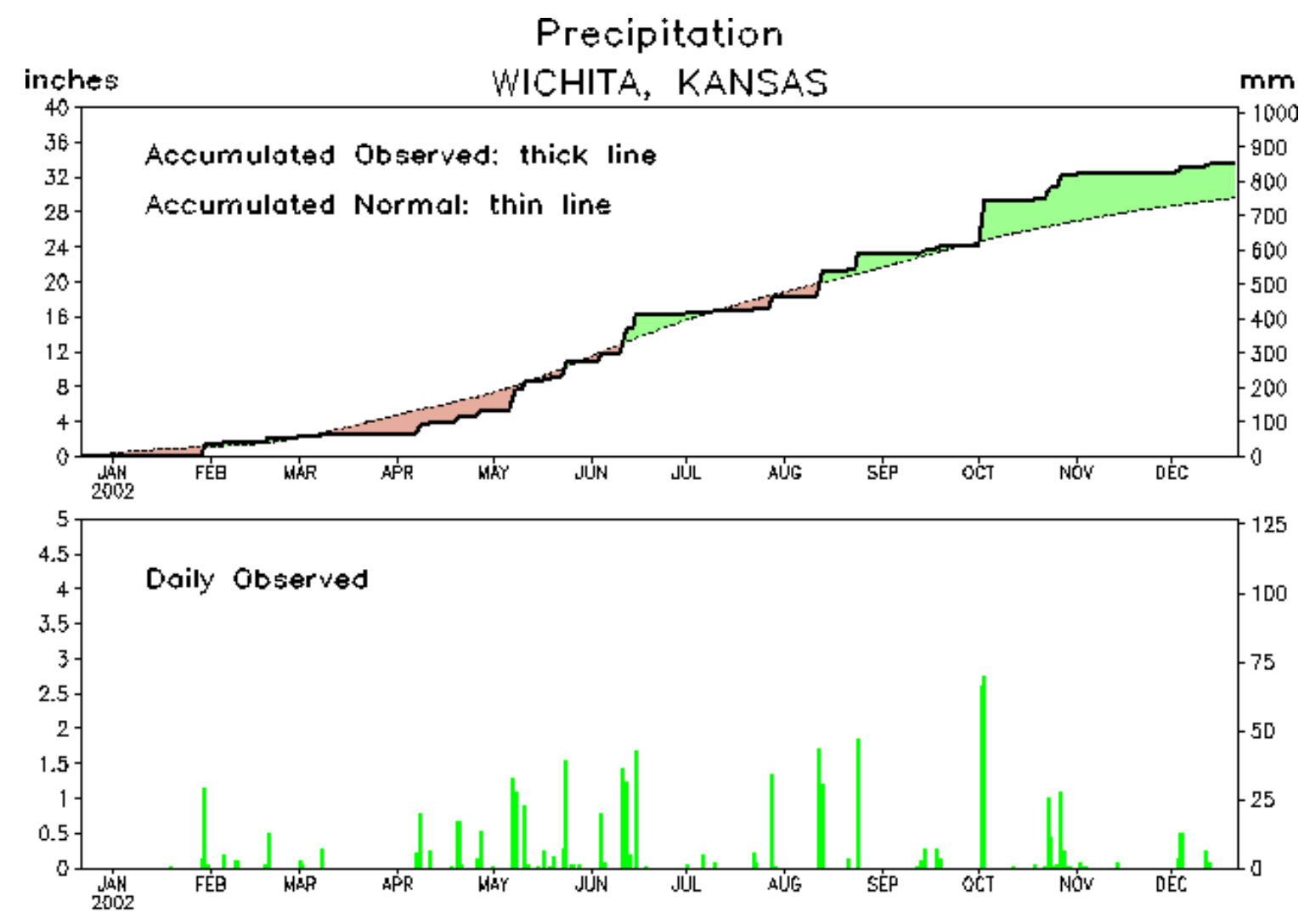

Doto updated through 21 DEC 2002

Figure 26: Annual Precipitation Summary for the Year 2002 at Wichita, Kansas.

Irrigation is clearly an economical remediation option to help leach salts from soil and to augment ion exchange in the clay particles of the surface soil. Costs will, however, vary depending upon the availability of suitable water supply. Other sources could include stock ponds, municipal water, rural water district, or private water well. 


\section{REFERENCES}

Carty, D.J., W.F. Priebe, and W. Crawley. 1997. Remediation of Salt-Affected Soils at Oil and Gas Production Facilities. American Petroleum Institute, Publication Number 4663.

Donahue, et al, 1983. Soils. Prentice-Hall, Inc. Englewood Cliffs, NJ.

Larcher, W. 1995. Physiological Plant Ecology. Springer-Verlag; Berlin.

Rahman, H.A., M.H. Dahab, and M.A. Mustafa. 1996. Impact of soil amendments on intermittent evaporation, moisture distribution and salt redistribution in saline-sodic clay soil columns. Soil Science 161(11): 797-802.

Richards, L.A., 1954. Diagnosis and Improvement of Saline and Alkali Soils. Agriculture Handbook 60, US Dept. of Ag. 


\section{APPENDIX I - Soil Sample Laboratory Data}

\author{
KANSAS STATE UNIVERSITY \\ SOIL TESTING LABORATORY \\ THROCKMORTON HALL \\ MANHATTAN, KS 66506 \\ (785)-532-7897
}

SUBMITTED BY: BRUCE LANGHUS

DATE: $4 / 17 / 01$

ALL CONSULTING, LLC

1305 E. 15TH ST., Suite 205

TULSA, OK 74120

ALT ALKALI - 4/17/01

Paste and Paste Extract Analysis

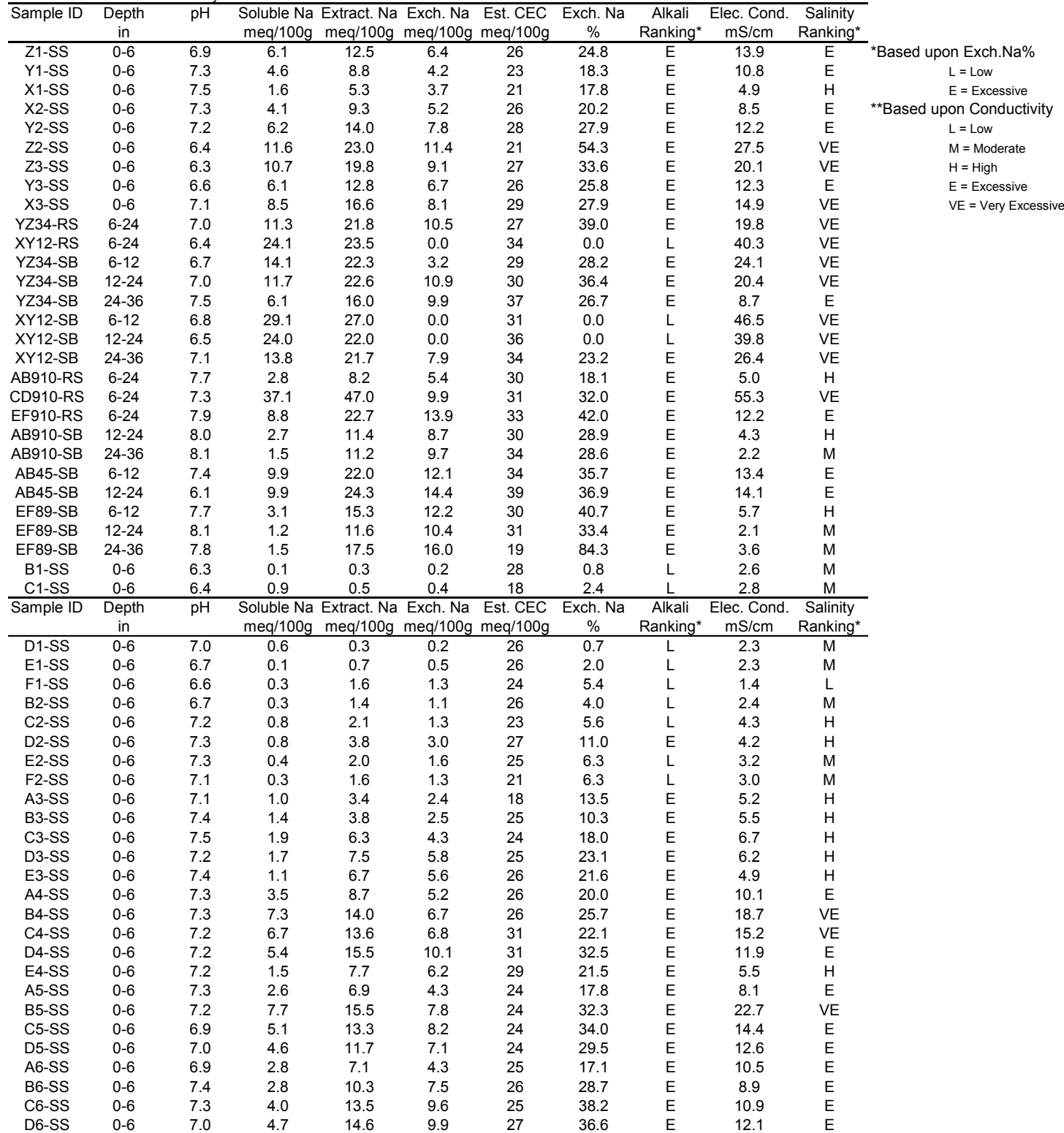




\section{4/17/01 Continued}

\begin{tabular}{|c|c|c|c|c|c|c|c|c|c|c|}
\hline A7-SS & $0-6$ & 7.1 & 2.0 & 4.3 & 2.8 & 24 & 11.5 & E & 8.2 & $E$ \\
\hline B7-SS & $0-6$ & 7.2 & 4.9 & 12.5 & 7.7 & 23 & 33.3 & E & 14.2 & $\mathrm{E}$ \\
\hline C7-SS & $0-6$ & 7.3 & 2.6 & 6.3 & 3.8 & 24 & 15.6 & E & 7.9 & $E$ \\
\hline D7-SS & $0-6$ & 7.4 & 13.7 & 17.8 & 4.1 & 25 & 16.4 & $\mathrm{E}$ & 29.2 & VE \\
\hline E7-SS & $0-6$ & 7.6 & 7.6 & 22.2 & 14.6 & 26 & 56.3 & E & 17.0 & VE \\
\hline A8-SS & $0-6$ & 7.4 & 1.4 & 4.5 & 3.1 & 26 & 11.8 & $\mathrm{E}$ & 6.0 & $\mathrm{H}$ \\
\hline B8-SS & $0-6$ & 7.4 & 2.0 & 6.8 & 4.1 & 26 & 15.7 & E & 6.8 & $\mathrm{H}$ \\
\hline C8-SS & $0-6$ & 7.0 & 10.1 & 20.7 & 10.6 & 26 & 40.9 & E & 25.9 & VE \\
\hline D8-SS & $0-6$ & 6.9 & 16.2 & 29.4 & 13.2 & 27 & 48.8 & E & 33.4 & VE \\
\hline E8-S & $0-6$ & 7.1 & 6.5 & 17.7 & 11.2 & 25 & 44.7 & E & 16.0 & VE \\
\hline F8-SS & $0-6$ & 7.3 & 12.8 & 25.5 & 12.7 & 25 & 50.6 & E & 28.8 & VE \\
\hline A9-SS & $0-6$ & 7.0 & 1.4 & 3.7 & 2.3 & 25 & 9.3 & L & 5.9 & $\mathrm{H}$ \\
\hline B9-SS & $0-6$ & 7.1 & 1.4 & 5.3 & 3.9 & 27 & 14.4 & E & 5.5 & $\mathrm{H}$ \\
\hline C9-SS & $0-6$ & 7.3 & 7.9 & 17.7 & 9.8 & 26 & 37.7 & E & 21.5 & VE \\
\hline D9-SS & $0-6$ & 7.1 & 2.0 & 19.0 & 17.0 & 27 & 63.1 & E & 15.9 & VE \\
\hline E9-SS & $0-6$ & 6.9 & 6.8 & 17.9 & 11.1 & 22 & 50.6 & $E$ & 22.1 & VE \\
\hline F9-SS & $0-6$ & 7.0 & 5.4 & 17.4 & 12.0 & 26 & 46.1 & $E$ & 15.3 & VE \\
\hline A10-SS & $0-6$ & 7.0 & 1.2 & 0.8 & 0.0 & 23 & 0.0 & L & 5.8 & $\mathrm{H}$ \\
\hline B10-SS & $0-6$ & 6.5 & 2.7 & 7.4 & 4.7 & 28 & 16.8 & $E$ & 8.2 & $E$ \\
\hline Sample ID & $\begin{array}{l}\text { Depth } \\
\text { in }\end{array}$ & $\mathrm{pH}$ & $\begin{array}{r}\text { Soluble Na } \\
\mathrm{meq} / 100 \mathrm{~g}\end{array}$ & $\begin{array}{c}\text { Extract. } \mathrm{Na} \\
\mathrm{meq} / 100 \mathrm{~g}\end{array}$ & $\begin{array}{l}\text { Exch. Na } \\
\text { meq } / 100 \mathrm{~g}\end{array}$ & $\begin{array}{l}\text { Est. CEC } \\
\text { meq } / 100 \mathrm{~g}\end{array}$ & $\begin{array}{c}\text { Exch. Na } \\
\%\end{array}$ & $\begin{array}{c}\text { Alkali } \\
\text { Ranking* }\end{array}$ & $\begin{array}{c}\text { Elec. Cond. } \\
\mathrm{mS} / \mathrm{cm}\end{array}$ & $\begin{array}{c}\text { Salinity } \\
\text { Ranking* }\end{array}$ \\
\hline C10-SS & $0-6$ & 7.1 & 5.4 & 7.8 & 2.4 & 23 & 10.3 & $E$ & 9.3 & $E$ \\
\hline D10-SS & $0-6$ & 7.2 & 8.4 & 17.5 & 9.1 & 26 & 35.0 & $E$ & 24.0 & VE \\
\hline E10-SS & $0-6$ & 6.9 & 7.9 & 14.5 & 6.6 & 26 & 25.4 & $\mathrm{E}$ & 12.4 & $\mathrm{E}$ \\
\hline F10-SS & $0-6$ & 6.8 & 6.2 & 10.3 & 4.1 & 25 & 16.3 & $\mathrm{E}$ & 12.6 & $\mathrm{E}$ \\
\hline BC12-RS & $6-24$ & 6.4 & 0.5 & 0.4 & 0.0 & 34 & 0.0 & L & 2.6 & M \\
\hline DE12-RS & $6-24$ & 6.8 & 0.0 & 0.3 & 0.3 & 26 & 1.1 & L & 2.2 & M \\
\hline AB34-RS & $6-24$ & 7.3 & 1.9 & 8.4 & 6.5 & 28 & 23.1 & $E$ & 5.8 & $\mathrm{H}$ \\
\hline CD34-RS & $6-24$ & 7.6 & 2.0 & 13.7 & 11.7 & 38 & 30.7 & $E$ & 5.1 & $\mathrm{H}$ \\
\hline AB56-RS & $6-24$ & 7.3 & 8.2 & 13.0 & 4.8 & 20 & 24.1 & $E$ & 17.3 & VE \\
\hline CD56-RS & $6-24$ & 7.6 & 8.4 & 19.3 & 10.9 & 34 & 32.2 & $E$ & 10.7 & E \\
\hline AB78-RS & $6-24$ & 7.4 & 1.7 & 22.6 & 21.0 & 28 & 74.8 & E & 21.3 & VE \\
\hline CD78-RS & $6-24$ & 7.2 & 2.9 & 32.0 & 29.1 & 28 & 104.0 & $E$ & 41.5 & VE \\
\hline EF78-RS & $6-24$ & 7.8 & 3.9 & 20.3 & 16.4 & 32 & 51.2 & E & 13.8 & E \\
\hline AB45-SB & $6-24$ & 7.6 & 8.1 & 13.2 & 5.1 & 18 & 28.3 & E & 17.1 & VE \\
\hline AB45-SB & $6-24$ & 7.8 & 5.9 & 22.8 & 17.0 & 28 & 60.5 & $\mathrm{E}$ & 15.6 & VE \\
\hline AB45-SB & $6-24$ & 7.9 & 5.6 & 21.9 & 16.3 & 34 & 47.9 & $\mathrm{E}$ & 12.4 & $\mathrm{E}$ \\
\hline
\end{tabular}


SUBMITTED BY: BRUCE LANGHUS

DATE: 10/29/01

ALL CONSULTING, LLC

1305 E. 15TH ST., Suite 205

TULSA, OK 74120

ALT ALKALI - 10/29/01

Paste and Paste Extract Analysis

Sample ID

Large Scar

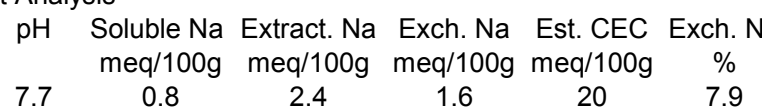

A-3

C-3

D-3

E-3

A-4

7.8

B-4 7.7

C-4 7.6

D-4 7.8

E-4 $\quad 7.8$

A-5 $\quad 7.7$

B-5 $\quad 7.6$

C-5 7.6

D-5 7.6

A-6 $\quad 7.6$

B-6 $\quad 7.6$

C-6 7.6

D-6 $\quad 7.7$

A-7 $\quad 7.7$

B-7 $\quad 7.5$

C-7 $\quad 7.6$

D-7 $\quad 7.6$

E-7 $\quad 7.8$

A-8 $\quad 7.8$

B-8 $\quad 7.6$

C-8 $\quad 7.5$

D-8 7.6

E-8 7.6

F-8 $\quad 7.7$

A-9 $\quad 7.8$

B-9 $\quad 7.7$

C-9 $\quad 7.7$

D-9 7.7

E-9 7.6

F-9 7.6

A-10 7.5

B-10 7.2

C-10 7.6

D-10 7.5

E-10 $\quad 7.5$

F-10

Small Scar

$\begin{array}{lllll}X-1 & 7.5 & 0.7 & 1.6 & 0.9\end{array}$

$\begin{array}{lllll}X-1 & 7.5 & 0.7 & 1.6 & 0.9 \\ X-2 & 7.5 & 1.4 & 3.7 & 2.4 \\ X-3 & 7.6 & 3.1 & 8.5 & 5.4\end{array}$

$\begin{array}{lllll}X-3 & 7.6 & 3.1 & 8.5\end{array}$

$\begin{array}{lllll}\mathrm{Y}-1 & 7.5 & 1.7 & 4.2 & 2.5 \\ \mathrm{Y}-2 & 7.5 & 2.2 & 6.8 & 4.6\end{array}$

$\begin{array}{lllll}\mathrm{Y}-2 & 7.5 & 2.2 & 6.8 & 4.6 \\ \mathrm{Y}-3 & 7.1 & 4.3 & 10.2\end{array}$

$\begin{array}{lllll}\mathrm{Y}-3 & 7.1 & 4.3 & 10.2 & 5.9\end{array}$

$\begin{array}{lllll}Z-1 & 7.4 & 1.6 & 3.6 & 2.0\end{array}$

$\begin{array}{lllll}Z-2 & 7.1 & 5.0 & 12.4 & 7.4\end{array}$

$$
\text { Z-3 }
$$

6.7

9.8 $\begin{array}{lll}1.6 & 20 & 7.9 \\ 0.2 & 19 & 1.3\end{array}$

0.9

2.1

0.8

4.9

4.6

4.2

7.6

1.3
3.8

6.4

5.4

5.9

2.1

5.8

5.8
2.0

8.0$$
\begin{aligned}
& 1.6 \\
& 5.5
\end{aligned}
$$

4.8
8.0

8.0
8.7

1.3

1.3
2.8
9.2

9.2
6.8

1.0
11.6

11.6

1.4
3.5

3.5
4.3

6.6

6.6
3.9

7.4
1.8

1.8
1.3

5.1
8.1

7.7

5.7

$0.9 \quad 22$

$2.4 \quad 23$

$5.4 \quad 21$

$2.5 \quad 21$

$6 \quad 25$

$5.9 \quad 20$

2.0
7.4

7.4

$Z-3-Y-3^{* * *}$

7.4

***Drip Point

${ }^{*}$ Based upon Exch.Na\%
L $=$ Low

$E=$ Excessive

7.3

22
22

5.6

10.1

4.7

24.4

23.1

22.3

29.3

6.2

21.3

31.8

30.1

21.8

11.8

26.2

10.2

32.0

9.3

30.7

25.2

36.3

39.5

6.1

13.6

41.9

30.9

4.7

52.8

7.1

16.8

21.4

31.6

19.5

37.1

9.2

7.1

28.1

42.6

35.0

Sample

Alkali Elec. Cond Salinity

Ranking* $\mathrm{mS} / \mathrm{cm}$ Ranking ${ }^{\star *}$

$\begin{array}{ccc}\mathrm{L} & 3.9 & \mathrm{H}\end{array}$

$\begin{array}{lll}L & 3.9 & \mathrm{M} \\ \mathrm{L} & 2.2 & \mathrm{M}\end{array}$

L $\quad 3.0$

E $\quad 3.8$

L $\quad 2.8$

E $\quad 9.2$

E $\quad 12.4$

E $\quad 8.7$

$\begin{array}{ll}\mathrm{E} & 13.0\end{array}$

L $\quad 3.9$

E $\quad 8.9$

\begin{tabular}{ll}
$E$ & 22.2 \\
\hline & 17.3
\end{tabular}

E $\quad 17.3$

E $\quad 10.1$

E 6.7

$\begin{array}{ll}E & 6.7 \\ E & 12.8\end{array}$

$\begin{array}{cc}E & 8.0 \\ E & 14.5\end{array}$

$\begin{array}{ll}\mathrm{L} & 5.3 \\ \mathrm{E} & 19.1\end{array}$

E $\quad 19.1$

$\begin{array}{ll}\text { E } & 11.9 \\ \text { E } & 21.4\end{array}$

$\begin{array}{ll}E & 21.4 \\ E & 11.3\end{array}$

E $\quad 11.3$

E $\quad 5.6$

$\begin{array}{ll}E & 31.5 \\ E & 13.4\end{array}$

$\begin{array}{ll}\mathrm{L} & 24.5 \\ \mathrm{E} & 24.2\end{array}$

L $\quad 4.9$

E 8.1

E $\quad 12.2$

$\begin{array}{ccc}E & 20.8 & \text { VE } \\ E & 8.6 & E\end{array}$

$\begin{array}{ccc}E & 8.6 & E \\ E & 18.5 & V E\end{array}$

$\begin{array}{ccc}E & 18.5 & \text { VE } \\ \mathrm{L} & 5.2 & \mathrm{H}\end{array}$

$\begin{array}{lll}\mathrm{L} & 5.2 & \mathrm{H} \\ \mathrm{L} & 6.5 & \mathrm{H}\end{array}$

E $\quad 13.4 \quad$ E

$\begin{array}{lll}\text { E } & 28.7 & \text { VE }\end{array}$

$\begin{array}{llll}28.6 & E & 21.1 & V E\end{array}$

$$
E=\text { Excessive }
$$

$\begin{array}{lccc}3.9 & \text { L } & 4.1 & \mathrm{H} \\ 10.3 & \mathrm{E} & 5.0 & \mathrm{H} \\ 25.7 & \mathrm{E} & 8.5 & \mathrm{E} \\ 11.9 & \mathrm{E} & 6.7 & \mathrm{H} \\ 18.5 & \mathrm{E} & 6.8 & \mathrm{H} \\ 29.5 & \mathrm{E} & 11.5 & \mathrm{E} \\ 9.2 & \mathrm{~L} & 6.0 & \mathrm{H} \\ 33.7 & \mathrm{E} & 12.4 & \mathrm{E} \\ 30.7 & \mathrm{E} & 22.0 & \mathrm{VE} \\ & & & \\ 31.7 & \mathrm{E} & 19.0 & \mathrm{VE} \\ & & \\ \text { Conductivity } & & \mathrm{H}=\text { High } \\ =\text { Low } & & \mathrm{E}=\text { Excessive } \\ =\text { Moderate } & & \mathrm{VE}=\text { Very Excessive }\end{array}$




\section{APPENDIX II - LEON SURFACE WATER QUALITY DATA}

\section{Leon Waterflood Site GPS Locations for Sampling Sites}

\begin{tabular}{|c|c|c|c|c|}
\hline Site & New \# & Latitude & Longitude & Site Description \\
\hline 1 & $\mathrm{~B}$ & 3741.229 & 9648.629 & Small pond $50 \mathrm{~m}$ north of north fence; sample at mid-dam \\
\hline 2 & C & 3741.218 & 9648.647 & Outflow $5 \mathrm{~m}$ south of the small pond $\mathbf{B}$ \\
\hline 3 & $\mathrm{D}$ & 3741.190 & 9648.652 & In stream just south of north fence, $30 \mathrm{~m}$ south of $\mathrm{C}$ \\
\hline 4 & $E$ & 3741.188 & 9648.637 & $10 \mathrm{~m}$ downstream from $\mathbf{D}$ in cattail marsh \\
\hline 5 & $\mathrm{~F}$ & 3741.189 & 9648.628 & $5 \mathrm{~m}$ SE. of $\mathrm{E}$ in cattail marsh \\
\hline 6 & G & 3741.179 & 9648.625 & East edge of first cattail marsh, $10 \mathrm{~m} \mathrm{SE}$ of $F$ \\
\hline 7 & $\mathrm{H}$ & 3741.163 & 9648.618 & Cattail marsh, approx. midway from north fence to middle pond \\
\hline 8 & $\mathrm{I}$ & 3741.126 & 9648.607 & North side of field road at culvert, just north of middle pond \\
\hline 9 & $\mathrm{~J}$ & 3741.125 & 9648.600 & In middle pond, $5 \mathrm{~m} E$ of culvert on north shore of pond \\
\hline 10 & & missing & missing & Drainage from tank scar to marsh; only sampled one time \\
\hline 11 & $\mathrm{~K}$ & 3741.080 & 9648.619 & In middle pond, off end of dock on west shore \\
\hline 12 & L & 3741.063 & 9648.587 & In middle pond, $1 / 3$ of way west of spillway on dam \\
\hline 13 & $\bar{M}$ & 3741.068 & 9648.569 & $10 \mathrm{~m}$ downstream of middle pond spillway \\
\hline 14 & & 3741.049 & 9648.582 & Small pool below dam (barrel); west of stream \\
\hline 15 & $\mathrm{~N}$ & missing & missing & $30 \mathrm{~m}$ downstream of spillway, scar area \\
\hline 16 & & 3741.036 & 9648.584 & First small pond, W. of stream below M.pond \\
\hline 17 & & 3741.017 & 9648.599 & Larger pond SW of \#16 \\
\hline 18 & & 3741.022 & 9648.592 & Small marsh NW of \#17, east side \\
\hline 19 & & 3741.024 & 9648.605 & Same marsh, west side \\
\hline 20 & $\mathrm{O}$ & 3741.009 & 9648.571 & In cattail marsh, SE of \#17 \\
\hline 21 & $\mathrm{P}$ & 3740.988 & 9648.577 & Cattail marsh, just $\mathrm{N}$ of fence \\
\hline 22 & & 3740.986 & 9648.551 & $30 \mathrm{~m} E$ ascending small tributary stream from \#21 \\
\hline 23 & Q & 3740.954 & 9648.590 & $30 \mathrm{~m} \mathrm{~S}$ of fence in cattail marsh \\
\hline 24 & $\mathrm{R}$ & 3740.941 & 9648.580 & Small pond, $60 \mathrm{~m} \mathrm{~S}$ of fence \\
\hline 25 & & 3740.935 & 9648.572 & Small backwater, between \#24 and \#26 \\
\hline 26 & & 3740.919 & 9648.557 & Large pond, south of fence, east of stream (outbuilding) \\
\hline 27 & & 3741.036 & 9648.442 & E. trib, W. side of road, east of Leon Site \\
\hline 28 & & 3741.060 & 9648.424 & E. trib, $50 \mathrm{~m} \mathrm{E}$ of road and \#27 \\
\hline 29 & & 3741.116 & 9648.530 & Sewage lagoon at mobile home \\
\hline 30 & & missing & missing & "trash pond", west of middle pond; bulldozed over in 2002 \\
\hline 31 & & missing & missing & Temporary pool N of breached pond, West Gully \\
\hline 32 & & missing & missing & West Gully, below tar spoil pile \\
\hline 33 & & 3740.880 & 9648.853 & Large pond south of fence, West Gully \\
\hline 34 & A & 3741.641 & 9648.719 & Culvert under SE 9th Road; $0.7 \mathrm{mi} . \mathrm{N}$. of site \\
\hline 35 & $\mathrm{~S}$ & 3740.773 & 9648.638 & Culvert at US 400 \\
\hline 36 & $T$ & 3739.889 & 9648.437 & L. Walnut River; $1.0 \mathrm{mi}$. S of US 400 at bridge \\
\hline 37 & & 3741.052 & 9648.856 & In New Pond Basin near dam, West Gully \\
\hline 38 & & 3741.087 & 9648.483 & N. end of New Pond; West Gully \\
\hline
\end{tabular}

Several stations were altered, abandoned or only sampled once, and were not GPS'd.

New \# = subset of all sample sites have been renamed to show upstream to downstream trends. Original site numbers are included for reference. 
Leon Waterflood Site - All Station Specific Conductivity (uS/cm)

\begin{tabular}{|c|c|c|c|c|c|c|c|c|c|c|c|c|c|c|c|c|}
\hline Site & New \# & 4/4/2001 & 4/30/2001 & $5 / 9 / 2001$ & $6 / 8 / 2001$ & 7/23/2001 & $10 / 25 / 2001$ & $3 / 1 / 2002$ & $4 / 29 / 2002$ & 6/14/2002 & $6 / 20 / 2002$ & 7/19/2002 & $8 / 8 / 2002$ & 9/23/2002 & $11 / 21 / 2002$ & Mean \\
\hline 1 & $B$ & 777 & 791 & 795 & 575 & 606 & 528 & 874 & 865 & 286 & 326 & 422 & 411 & 417 & 604 & 591 \\
\hline 2 & $C$ & 774 & 738 & 803 & 564 & - & - & - & - & 287 & 375 & - & - & - & - & 590 \\
\hline 3 & $\mathrm{D}$ & 836 & 931 & 938 & 558 & - & - & - & - & - & - & - & - & - & 2230 & 1099 \\
\hline 4 & $\mathrm{E}$ & 857 & 1120 & 950 & 545 & - & - & - & - & 656 & 773 & 943 & - & - & 1410 & 907 \\
\hline 5 & $\mathrm{~F}$ & 968 & 1350 & 1150 & 542 & - & - & - & - & 503 & 630 & 951 & 1190 & - & 1510 & 977 \\
\hline 6 & $G$ & 1180 & 1360 & 1180 & 522 & 1880 & - & - & 3440 & 468 & 581 & 922 & 1230 & - & 1450 & 1292 \\
\hline 7 & $\mathrm{H}$ & 1320 & 1440 & 1330 & 745 & 1800 & - & - & 3420 & 414 & 542 & 892 & 1160 & - & 1360 & 1311 \\
\hline 8 & $\mathrm{I}$ & 1360 & 1230 & 1410 & 1170 & 1100 & - & - & - & 389 & 516 & 531 & 480 & 799 & 835 & 893 \\
\hline 9 & $\mathrm{~J}$ & 783 & 910 & 904 & 514 & 1170 & - & - & - & 393 & 392 & 397 & 477 & - & 605 & 655 \\
\hline 10 & & - & - & - & 243 & - & - & - & - & - & - & - & - & - & - & 0 \\
\hline 12 & $\mathrm{~L}$ & 728 & 893 & 903 & 723 & 830 & 1250 & 1460 & 1600 & 395 & 389 & 403 & 412 & 487 & 587 & 790 \\
\hline 13 & $M$ & 754 & 2870 & 970 & 730 & - & - & - & - & 399 & 405 & - & - & - & - & 1021 \\
\hline 14 & & 1730 & 1860 & 1430 & 717 & - & - & - & - & 1180 & 1230 & - & - & - & 2480 & 1518 \\
\hline 15 & $\mathrm{~N}$ & 1250 & 2030 & 1610 & 734 & - & - & - & - & 453 & 840 & - & - & - & - & 1153 \\
\hline 16 & & 1990 & 1940 & 1290 & 704 & 2330 & 920 & 1020 & 692 & 583 & 921 & 2810 & 1130 & 1510 & 2650 & 1464 \\
\hline 17 & & 1530 & 1770 & 1650 & 791 & - & - & - & 3660 & 584 & 1040 & - & - & - & 2680 & 1713 \\
\hline 18 & & 2470 & 2730 & 2530 & 1870 & - & - & - & - & 2580 & 2840 & 2100 & - & - & 3150 & 2534 \\
\hline 19 & & 1800 & 2190 & 2360 & 990 & - & - & - & - & 2180 & 1370 & 1990 & - & - & 2540 & 1928 \\
\hline 20 & 0 & 1480 & 2490 & 2000 & 752 & - & - & - & - & 490 & 960 & - & - & - & 2450 & 1517 \\
\hline 21 & $\mathrm{P}$ & 1720 & 2700 & 2120 & 764 & - & - & - & - & 501 & 1020 & - & - & - & 3080 & 1701 \\
\hline 24 & $R$ & 1310 & 1400 & 1490 & 602 & 1570 & - & - & 1750 & 494 & 674 & 990 & - & - & 1980 & 1226 \\
\hline 25 & & 1240 & 1180 & 1330 & 538 & - & - & - & - & 1920 & 2200 & 2420 & - & - & 3270 & 1762 \\
\hline 26 & & 207 & 235 & 220 & 110 & 131 & 99 & 410 & 313 & 138 & 144 & 160 & 160 & 162 & 188 & 191 \\
\hline 27 & & 645 & - & - & 178 & - & - & - & 346 & 503 & 585 & - & - & - & 663 & 487 \\
\hline 28 & & 674 & 704 & 542 & 141 & 566 & - & - & - & 373 & 618 & 463 & - & - & 639 & 524 \\
\hline 29 & & 467 & 475 & 479 & 427 & 487 & 505 & 630 & 639 & 469 & 470 & 543 & 596 & 685 & 558 & 531 \\
\hline 30 & & 373 & 447 & 393 & 287 & - & - & - & - & - & - & - & - & - & - & 375 \\
\hline 31 & & 265 & - & 242 & 82 & - & - & - & - & - & - & - & - & - & - & 265 \\
\hline 32 & & 4900 & - & 2450 & 534 & - & - & 2640 & 860 & 320 & 1330 & - & - & - & - & 1862 \\
\hline 33 & & 379 & 412 & 408 & 356 & 460 & 367 & 674 & 537 & 205 & 230 & 299 & 322 & 324 & 421 & 385 \\
\hline 34 & $A$ & 334 & 343 & 222 & 73 & 227 & - & 0 & 281 & 107 & 132 & - & 258 & - & 231 & 201 \\
\hline 35 & $\mathrm{~s}$ & 1120 & 873 & 1160 & 592 & 696 & 0 & 1410 & 1660 & 617 & 0 & 1220 & 0 & 0 & 1660 & 786 \\
\hline 36 & $T$ & 474 & 538 & 534 & 179 & 395 & 276 & 554 & 424 & 210 & 289 & 462 & 474 & 511 & 497 & 416 \\
\hline 37 & & - & - & 0 & 0 & 0 & - & 9930 & 2300 & 306 & 297 & 437 & 540 & 779 & 533 & 1375 \\
\hline 38 & & - & - & 0 & 0 & 0 & 0 & 0 & 0 & 308 & 298 & 436 & 546 & 779 & 528 & 241 \\
\hline 39 & & - & - & - & 589 & - & - & - & - & - & - & - & - & - & - & 589 \\
\hline 40 & & - & - & - & 224 & - & - & - & - & - & - & - & - & - & - & 224 \\
\hline 41 & & - & - & 136 & 59 & - & - & - & - & - & - & - & - & - & - & 98 \\
\hline Mean & & 1136 & 1315 & 1064 & 522 & 839 & 520 & 1625 & 1355 & 593 & 716 & 890 & 576 & 579 & 1454 & \\
\hline
\end{tabular}

New \# = subset of all sample sites have been renamed to show upstream to downstream

trends. Original site numbers are included for reference. 


\section{Leon Waterflood - All Station Salinity Data (Weight \%)}

\begin{tabular}{|c|c|c|c|c|c|c|c|c|c|c|c|c|c|c|c|c|}
\hline Site & New \# & $4 / 4 / 2001$ & 4/30/2001 & $5 / 9 / 2001$ & $6 / 8 / 2001$ & 7/23/2001 & 10/25/2001 & $3 / 1 / 2002$ & 4/29/2002 & $6 / 14 / 2002$ & 6/20/2002 & 7/19/2002 & $8 / 8 / 2002$ & 9/23/2002 & $11 / 21 / 2002$ & Mean \\
\hline 1 & B & 0.03 & 0.03 & 0.03 & 0.02 & 0.02 & 0.02 & 0.03 & 0.03 & 0.01 & 0.01 & 0.01 & 0.01 & 0.01 & 0.02 & 0.02 \\
\hline 2 & $C$ & 0.03 & 0.03 & 0.03 & 0.02 & - & - & - & - & 0.01 & 0.01 & - & - & - & - & 0.02 \\
\hline 3 & $\mathrm{D}$ & 0.03 & 0.04 & 0.04 & 0.02 & - & - & - & - & - & - & - & - & - & 0.1 & 0.05 \\
\hline 4 & $\mathrm{E}$ & 0.03 & 0.05 & 0.04 & 0.02 & - & - & - & - & 0.02 & 0.03 & 0.04 & - & - & 0.06 & 0.04 \\
\hline 5 & $\mathrm{~F}$ & 0.04 & 0.06 & 0.05 & 0.02 & - & - & - & - & 0.02 & 0.02 & 0.04 & 0.05 & - & 0.06 & 0.04 \\
\hline 6 & G & 0.05 & 0.06 & 0.05 & 0.02 & 0.08 & - & - & 0.17 & 0.01 & 0.02 & 0.04 & 0.05 & - & 0.06 & 0.06 \\
\hline 7 & $\mathrm{H}$ & 0.06 & 0.06 & 0.06 & 0.03 & 0.08 & - & - & 0.16 & 0.01 & 0.02 & 0.03 & 0.05 & - & 0.06 & 0.06 \\
\hline 8 & 1 & 0.06 & 0.05 & 0.06 & 0.04 & 0.04 & - & - & - & 0.01 & 0.02 & 0.02 & 0.02 & 0.03 & 0.03 & 0.03 \\
\hline 9 & $\mathrm{~J}$ & 0.03 & 0.03 & 0.03 & 0.02 & 0.05 & - & - & - & 0.01 & 0.01 & 0.01 & 0.01 & - & 0.02 & 0.02 \\
\hline 10 & & - & - & - & 0.03 & - & - & - & - & - & - & - & - & - & - & 0.03 \\
\hline 11 & $\mathrm{~K}$ & 0.03 & 0.03 & 0.04 & 0.03 & 0.03 & 0.05 & 0.06 & 0.07 & 0.01 & 0.01 & 0.01 & 0.01 & 0.02 & 0.02 & 0.03 \\
\hline 12 & $\mathrm{~L}$ & 0.03 & 0.03 & 0.03 & 0.03 & 0.03 & 0.05 & 0.06 & 0.07 & 0.01 & 0.01 & 0.01 & 0.01 & 0.02 & 0.02 & 0.03 \\
\hline 13 & $M$ & 0.03 & 0.13 & 0.04 & 0.03 & - & - & - & - & 0.01 & 0.01 & - & - & - & - & 0.04 \\
\hline 14 & & 0.08 & 0.08 & 0.06 & 0.03 & - & - & - & - & 0.05 & 0.05 & - & - & - & 0.11 & 0.07 \\
\hline 15 & $\mathrm{~N}$ & 0.05 & 0.09 & 0.07 & 0.03 & - & - & - & - & 0.01 & 0.03 & - & - & - & - & 0.05 \\
\hline 16 & & 0.09 & 0.09 & 0.05 & 0.03 & 0.11 & 0.04 & 0.04 & 0.02 & 0.02 & 0.04 & 0.13 & 0.05 & 0.07 & 0.12 & $\begin{array}{l}0.06 \\
\end{array}$ \\
\hline 17 & & 0.07 & 0.08 & 0.07 & 0.03 & - & - & - & 0.18 & 0.02 & 0.04 & - & - & - & 0.12 & $\begin{array}{l}0.08 \\
\end{array}$ \\
\hline 18 & & 0.11 & 0.13 & 0.12 & 0.07 & - & - & - & - & 0.12 & $\begin{array}{l}0.14 \\
\end{array}$ & 0.1 & - & - & 0.15 & $\begin{array}{l}0.12 \\
\end{array}$ \\
\hline 19 & & 0.08 & $\begin{array}{ll}0.1 \\
\end{array}$ & $\begin{array}{ll}0.11 \\
\end{array}$ & 0.04 & - & - & - & - & 0.1 & 0.06 & 0.09 & - & - & 0.12 & 0.09 \\
\hline 20 & 0 & 0.06 & 0.12 & 0.09 & 0.03 & - & - & - & - & 0.02 & 0.04 & - & - & - & 0.11 & 0.07 \\
\hline 21 & $P$ & 0.08 & 0.13 & 0.1 & 0.03 & - & - & - & - & 0.02 & 0.04 & - & - & - & 0.14 & $\begin{array}{l}0.08 \\
\end{array}$ \\
\hline 22 & & 0.03 & 0.02 & 0.03 & 0 & - & - & - & - & 0.02 & 0.02 & 0.01 & - & - & 0.03 & 0.02 \\
\hline 23 & $Q$ & 0.07 & 0.13 & 0.08 & 0.03 & - & - & - & - & 0.02 & 0.04 & - & - & - & 0.14 & 0.07 \\
\hline 24 & $R$ & 0.05 & 0.06 & 0.06 & 0.02 & 0.07 & - & - & 0.08 & 0.02 & 0.02 & 0.04 & - & - & 0.09 & 0.05 \\
\hline 25 & & 0.05 & 0.05 & 0.06 & 0.02 & - & - & - & - & 0.09 & 0.1 & 0.11 & - & - & 0.16 & $\begin{array}{l}0.08 \\
\end{array}$ \\
\hline 26 & & 0 & 0 & 0 & 0 & 0 & 0 & 0.01 & 0.01 & 0 & 0 & 0 & 0 & 0 & 0 & 0.00 \\
\hline 27 & & 0.02 & - & - & 0 & - & - & - & 0.01 & 0.02 & 0.02 & - & - & - & 0.02 & 0.02 \\
\hline 28 & & 0.02 & 0.03 & 0.02 & 0 & 0.02 & - & - & - & 0.01 & 0.02 & 0.01 & - & - & 0.02 & 0.02 \\
\hline 29 & & 0.01 & 0.01 & 0.01 & 0.01 & 0.02 & $\begin{array}{l}0.02 \\
\end{array}$ & 0.12 & 0.02 & 0.01 & 0.01 & 0.02 & 0.02 & 0.02 & 0.02 & $\begin{array}{l}0.02 \\
\end{array}$ \\
\hline 30 & & 0.01 & 0.01 & 0.01 & 0.01 & - & - & - & - & - & - & - & - & - & - & 0.01 \\
\hline 31 & & 0.01 & - & 0 & 0 & - & - & - & - & - & - & - & - & - & - & 0.00 \\
\hline 32 & & 0.25 & - & 0.12 & 0.02 & - & - & 0.12 & 0.03 & 0.01 & 0.06 & - & - & - & - & 0.09 \\
\hline 33 & & 0.01 & 0.01 & 0.01 & 0.01 & 0.01 & 0.01 & 0.02 & 0.02 & 0 & 0 & 0.01 & 0.01 & 0.01 & 0.01 & 0.01 \\
\hline 34 & $\mathrm{~A}$ & 0.01 & 0.01 & 0 & 0 & 0 & - & & 0.01 & 0 & 0 & - & 0.01 & - & 0 & 0.00 \\
\hline 35 & $\mathrm{~S}$ & 0.05 & 0.03 & 0.05 & 0.02 & 0.03 & & 0.06 & 0.07 & 0.02 & & 0.05 & & & 0.07 & 0.05 \\
\hline 36 & $T$ & 0.01 & 0.02 & 0.02 & 0 & 0.01 & 0.01 & 0.02 & 0.01 & 0 & 0.01 & 0.01 & 0.01 & 0.02 & 0.01 & 0.01 \\
\hline 37 & & - & - & - & - & - & - & 0.52 & 0.11 & 0.01 & 0.01 & 0.01 & 0.02 & 0.03 & 0.02 & 0.09 \\
\hline 38 & & - & - & - & - & - & - & - & - & 0.01 & 0.01 & 0.01 & 0.02 & 0.03 & 0.02 & 0.02 \\
\hline 39 & & - & - & - & $\begin{array}{l}0.02 \\
\end{array}$ & - & - & - & - & - & 0.04 & - & - & - & - & 0.03 \\
\hline 40 & & - & - & - & 0 & - & - & - & - & - & - & - & - & - & - & 0 \\
\hline 41 & & - & - & 0 & 0 & - & - & - & - & - & - & - & - & - & - & 0 \\
\hline Mean & & 0.05 & 0.06 & 0.05 & 0.02 & 0.04 & 0.03 & 0.10 & 0.06 & 0.02 & 0.03 & 0.04 & 0.02 & 0.02 & 0.06 & \\
\hline
\end{tabular}

New \# = subset of all sample sites have been renamed to show upstream to downstream trends.

Original site numbers are included for reference. 


\section{Leon Waterflood - All Station Dissolved Oxygen (mg/L)}

\begin{tabular}{|c|c|c|c|c|c|c|c|c|c|c|c|c|c|c|c|c|}
\hline Site & New \# & $4 / 4 / 01$ & $4 / 30 / 01$ & $5 / 9 / 01$ & $6 / 8 / 01$ & $7 / 23 / 01$ & $10 / 25 / 01$ & $3 / 1 / 02$ & $4 / 29 / 02$ & $6 / 14 / 02$ & $6 / 20 / 02$ & $7 / 19 / 02$ & $8 / 8 / 02$ & $9 / 23 / 02$ & $11 / 21 / 02$ & Mean \\
\hline 1 & $B$ & 10.95 & 10.95 & 6.14 & 10.76 & 6.06 & 7.59 & 12.85 & 10.35 & 3.92 & 7.94 & 6.86 & 7.21 & 5.62 & 4.12 & 7.95 \\
\hline 2 & $C$ & 12.13 & 13.24 & 5.49 & 10.55 & - & - & - & - & 7.17 & 8.97 & - & - & - & - & 9.59 \\
\hline 3 & $\mathrm{D}$ & 10.90 & 11.74 & 9.01 & 8.55 & - & - & - & - & - & - & - & - & - & 4.37 & 8.91 \\
\hline 4 & $E$ & 4.56 & 5.48 & 7.17 & 7.96 & - & - & - & - & 4.52 & 11.50 & 6.62 & - & - & 10.26 & 7.26 \\
\hline 5 & $\mathrm{~F}$ & 5.66 & 7.57 & 5.46 & 7.82 & - & - & - & - & 2.78 & 4.54 & 1.85 & 11.51 & - & 10.31 & 6.39 \\
\hline 6 & $G$ & 7.50 & 6.87 & 3.88 & 7.30 & 15.52 & - & - & 17.89 & 3.16 & 4.81 & 2.52 & 11.70 & - & 10.28 & 8.31 \\
\hline 7 & $\mathrm{H}$ & 5.46 & 7.26 & 1.49 & 2.27 & 6.93 & - & - & 15.66 & 2.57 & 3.31 & 2.52 & 12.66 & - & 10.11 & 6.39 \\
\hline 8 & 1 & 3.87 & 6.64 & 5.27 & 1.93 & 3.56 & - & - & - & 2.57 & 7.28 & 0.67 & 5.33 & 1.80 & 9.11 & 4.37 \\
\hline 9 & $\mathrm{~J}$ & 7.24 & 10.36 & 11.26 & 3.89 & 13.57 & - & - & - & 3.13 & 18.53 & 10.52 & 9.94 & - & 11.34 & 9.98 \\
\hline 10 & & - & - & - & 6.51 & - & - & - & - & - & - & - & - & - & 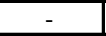 & 6.51 \\
\hline 11 & $\mathrm{~K}$ & 8.61 & 8.96 & 10.93 & 6.57 & 12.45 & 10.76 & 14.58 & 14.54 & 4.46 & 19.99 & 7.77 & 6.64 & 6.20 & 10.99 & 10.25 \\
\hline 12 & $\mathrm{~L}$ & 8.58 & 9.57 & 11.72 & 7.77 & 9.14 & 10.36 & 14.93 & 11.80 & 5.14 & 19.99 & 7.95 & 7.39 & 8.11 & 10.85 & 10.24 \\
\hline 13 & $M$ & 11.73 & 7.10 & 8.48 & 7.47 & - & - & - & - & 5.88 & 9.45 & - & - & - & - & 8.35 \\
\hline 14 & & 11.11 & 11.98 & 9.40 & 3.12 & - & - & - & - & 3.48 & 12.76 & - & - & - & 4.17 & 8.00 \\
\hline 15 & $\mathrm{~N}$ & 8.54 & 5.79 & 4.79 & 7.23 & - & - & - & - & 3.80 & 3.85 & - & - & - & - & 5.67 \\
\hline 16 & & 8.70 & 9.27 & 8.30 & 7.02 & 7.99 & 10.30 & 12.36 & 11.02 & 7.75 & 9.83 & 2.72 & 7.90 & 7.16 & 7.01 & 8.38 \\
\hline 17 & & 13.47 & 9.55 & 8.10 & 6.37 & - & - & - & 17.36 & 4.50 & 8.91 & - & - & - & 7.52 & 9.47 \\
\hline 18 & & 6.36 & 13.97 & 9.10 & 2.82 & - & - & - & - & 5.48 & 6.96 & 7.38 & - & - & 2.82 & 6.86 \\
\hline 19 & & 3.60 & 10.21 & 8.77 & 5.88 & - & - & - & - & 4.51 & 3.65 & 7.51 & - & - & 3.96 & 6.01 \\
\hline 20 & 0 & 7.55 & 8.05 & 8.60 & 6.21 & - & - & - & - & 4.55 & 3.88 & - & - & - & 8.83 & 6.81 \\
\hline 21 & $P$ & 10.17 & 13.39 & 7.43 & 6.42 & - & - & - & - & 4.65 & 4.41 & - & - & - & 8.63 & 7.87 \\
\hline 22 & & 8.51 & 9.50 & 9.55 & 7.11 & - & - & - & - & 7.04 & 9.06 & 5.59 & - & - & 5.43 & 7.72 \\
\hline 23 & $Q$ & 10.80 & 9.85 & 7.25 & 6.66 & - & - & - & - & 4.71 & 5.21 & - & - & - & 7.56 & 7.43 \\
\hline 24 & $R$ & 12.74 & 10.15 & 10.09 & 6.21 & 11.52 & - & - & 11.48 & 4.89 & 7.39 & 1.19 & - & - & 8.60 & 8.43 \\
\hline 25 & & 1.90 & 1.55 & 2.02 & 4.48 & - & - & - & - & 2.90 & 1.55 & 4.81 & - & - & 1.23 & 2.56 \\
\hline 26 & & 10.46 & 9.09 & 9.59 & 9.59 & 12.36 & 12.10 & 13.12 & 14.34 & 5.50 & 8.75 & 6.99 & 7.24 & 7.02 & 10.68 & 9.77 \\
\hline 27 & & 9.45 & - & - & 6.62 & - & - & - & 7.36 & 5.46 & 7.21 & - & - & - & 4.34 & 6.74 \\
\hline 28 & & 11.47 & 8.37 & 10.46 & 5.94 & 2.38 & - & - & - & 2.31 & 6.04 & 5.41 & - & - & 9.41 & 6.87 \\
\hline 29 & & 13.00 & 9.56 & 19.99 & 0.00 & 0.65 & 12.18 & 19.99 & 19.99 & 7.36 & 2.65 & 1.61 & 0.28 & 0.35 & 4.70 & 8.02 \\
\hline 30 & & 9.22 & 8.82 & 10.70 & 5.11 & - & - & - & - & - & - & - & - & - & - & 8.46 \\
\hline 31 & & 9.20 & - & 8.78 & 6.60 & - & - & - & - & - & - & - & - & - & - & 8.19 \\
\hline 32 & & 8.50 & - & 5.74 & 5.82 & - & - & 14.21 & 4.71 & 5.72 & 12.07 & - & - & - & - & 8.11 \\
\hline 33 & & 9.93 & 8.87 & 8.66 & 6.10 & 7.46 & 10.05 & 12.94 & 9.91 & 5.42 & 8.34 & 7.33 & 6.65 & 7.23 & 9.69 & 8.47 \\
\hline 34 & $A$ & 8.67 & 8.67 & 2.62 & 6.57 & 2.55 & - & - & 2.81 & 4.70 & 5.40 & - & 2.87 & - & 1.61 & 4.65 \\
\hline 35 & $\mathrm{~s}$ & 13.34 & 11.90 & 9.32 & 5.93 & 3.59 & - & 9.11 & 5.61 & 5.50 & - & 3.24 & - & - & 2.93 & 7.05 \\
\hline 36 & $T$ & 10.90 & 7.67 & 7.31 & 6.73 & 9.37 & 5.54 & 12.92 & 7.87 & 5.38 & 7.24 & 6.52 & 5.60 & 4.32 & 9.28 & 7.62 \\
\hline 37 & & - & - & - & - & - & - & 9.38 & 7.96 & 4.72 & 7.57 & 6.43 & 6.02 & 6.32 & 10.02 & 7.30 \\
\hline 38 & & - & - & - & - & - & - & - & - & 4.41 & 8.03 & 6.70 & 6.04 & 6.89 & 10.63 & 7.12 \\
\hline 39 & & - & - & - & 7.25 & - & - & - & - & - & 7.37 & - & - & - & - & 7.25 \\
\hline 40 & & - & - & - & 7.12 & - & - & - & - & - & - & - & - & - & - & 7.12 \\
\hline 41 & & - & - & 5.68 & 4.23 & - & - & - & - & - & - & - & - & - & - & 4.96 \\
\hline Mean & & 8.99 & 9.12 & 7.96 & 6.22 & 7.82 & 9.86 & 13.31 & 11.22 & 4.71 & 8.07 & 5.25 & 7.19 & 5.55 & 7.44 & \\
\hline
\end{tabular}




\section{Leon Waterflood - All Stations pH}

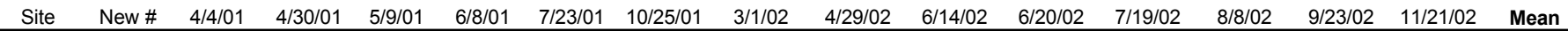

\begin{tabular}{|c|c|c|c|c|c|c|c|c|c|c|c|c|c|c|c|c|}
\hline & & & & & & & & & & & & & & & & \\
\hline 1 & $B$ & 8.53 & 8.47 & 8.14 & 9.65 & 9.09 & 8.64 & 9.76 & 9.54 & 7.75 & 8.77 & 9.14 & 9.61 & 8.90 & 7.65 & 8.83 \\
\hline 2 & $C$ & 8.44 & 8.59 & 7.88 & 9.64 & - & - & - & - & 8.59 & 8.59 & - & - & - & - & 8.62 \\
\hline 3 & $D$ & 8.30 & 8.20 & 7.74 & 9.30 & - & - & - & - & - & - & - & - & - & 7.64 & 8.24 \\
\hline 4 & $E$ & 8.00 & 7.78 & 7.60 & 9.15 & - & - & - & - & 7.5 & 8.06 & 8.62 & - & - & $\begin{array}{l}7.66 \\
\end{array}$ & 8.05 \\
\hline 5 & $F$ & 7.80 & 7.70 & 7.52 & 9.06 & - & - & - & - & 7.48 & 8.04 & 8.17 & 10.32 & - & 7.82 & 8.21 \\
\hline 6 & $G$ & 7.69 & 7.69 & 7.43 & 8.91 & 8.26 & - & - & 9.54 & 7.45 & 7.98 & 8.25 & 9.65 & - & 7.78 & 8.24 \\
\hline 7 & $\mathrm{H}$ & 7.68 & 7.73 & 7.42 & $\begin{array}{l}7.38 \\
\end{array}$ & 7.26 & - & - & 9.51 & 7.4 & 7.91 & 8.05 & 8.82 & - & $\begin{array}{ll}7.71 \\
\end{array}$ & 7.90 \\
\hline 8 & 1 & 7.73 & 7.77 & 7.45 & 7.26 & 7.55 & - & - & - & 7.48 & 8.24 & 8.42 & 9.53 & 7.76 & 7.39 & 7.87 \\
\hline 9 & $\mathrm{~J}$ & 7.79 & 8.05 & 8.34 & 7.51 & 9.05 & - & - & - & 7.39 & 10.49 & 10.47 & 10.32 & - & 8.02 & 8.74 \\
\hline 10 & - & - & - & - & 7.97 & & - & - & - & - & - & - & - & - & - & 7.97 \\
\hline 11 & $\mathrm{~K}$ & 8.00 & 8.20 & 8.46 & 9.21 & 9.58 & 9.17 & 9.65 & 9.68 & 7.66 & 10.53 & 10.04 & 10.05 & 8.80 & 8.60 & 9.12 \\
\hline 12 & $\mathrm{~L}$ & 8.03 & 8.24 & 8.45 & 9.43 & 9.13 & 9.21 & 9.64 & 9.25 & 7.77 & 10.39 & 10.04 & 9.96 & 9.15 & 8.64 & 9.10 \\
\hline 13 & $M$ & 8.24 & 7.92 & 8.43 & 9.46 & - & - & - & - & 7.99 & 9.92 & - & - & - & - & 8.66 \\
\hline 14 & - & 8.16 & 8.10 & 8.20 & 7.78 & - & - & - & - & 7.43 & 8.62 & - & - & - & 7.49 & 7.97 \\
\hline 15 & $\mathrm{~N}$ & 7.95 & 7.72 & 7.72 & 9.35 & - & - & - & - & 7.55 & 8.14 & - & - & - & - & 8.07 \\
\hline 16 & - & 8.41 & 8.50 & 8.50 & 8.86 & 8.62 & 8.61 & 9.31 & 9.42 & 8.49 & 9.16 & 8.03 & $\begin{array}{l}10.08 \\
\end{array}$ & 8.42 & 7.69 & 8.72 \\
\hline 17 & - & 8.53 & 8.31 & 7.88 & 8.32 & - & - & - & 9.01 & 7.65 & 8.88 & - & - & - & 7.85 & 8.30 \\
\hline 18 & - & 8.04 & 8.21 & 8.02 & 7.11 & - & - & - & - & 7.55 & 8.36 & 9.44 & - & - & 7.48 & 8.03 \\
\hline 19 & - & 7.61 & 7.83 & 7.7 & 7.16 & - & - & - & - & 7.37 & 7.77 & 9.37 & - & - & 7.28 & 7.76 \\
\hline 20 & 0 & 7.87 & 8.11 & 7.74 & 8.96 & - & - & - & - & 7.71 & 8.1 & - & - & - & 7.83 & 8.05 \\
\hline 21 & $P$ & 7.96 & 8.11 & 7.73 & 8.67 & - & - & - & - & 7.71 & 8.08 & - & - & - & 7.79 & 8.01 \\
\hline 22 & - & 7.92 & 8.26 & 7.96 & 7.97 & - & - & - & - & 8.03 & 8.6 & 9.1 & - & - & 7.82 & 8.21 \\
\hline 23 & $Q$ & 8.05 & 8.06 & 7.96 & 8.65 & - & - & - & - & 7.79 & 8.32 & - & - & - & 7.58 & 8.06 \\
\hline 24 & $\mathrm{R}$ & 8.13 & 7.96 & 7.94 & 8.13 & 8.45 & - & - & 8.51 & 7.82 & 8.6 & 8.59 & - & - & 8.02 & 8.22 \\
\hline 25 & - & 7.68 & 7.62 & 7.51 & 7.51 & - & - & - & - & 7.29 & 7.74 & $\begin{array}{l}7.63 \\
\end{array}$ & - & - & 7.02 & 7.50 \\
\hline 26 & - & 8.10 & 8.17 & 8.26 & 9.29 & 9.67 & 10.05 & 8.92 & 10.44 & 8.09 & 9.1 & 9.80 & 10.12 & 8.92 & 8.70 & 9.12 \\
\hline 27 & - & 8.12 & - & - & 7.85 & - & - & - & 8.32 & 7.55 & 8.08 & - & - & - & 7.39 & 7.89 \\
\hline 28 & - & 7.96 & 8.06 & 8.03 & 7.68 & 7.80 & - & - & - & 7.51 & 8.24 & 9.01 & - & - & 8.05 & 8.04 \\
\hline 29 & - & 9.41 & 9.24 & 9.75 & 7.23 & 6.88 & 8.16 & 9.51 & 9.72 & 7.75 & 8.05 & 7.93 & 7.81 & 6.89 & 7.90 & 8.30 \\
\hline 30 & - & 8.10 & 8.07 & 8.12 & 7.64 & - & - & - & - & - & - & - & - & - & - & 7.98 \\
\hline 31 & - & 8.37 & - & 8.05 & 7.54 & - & - & - & - & - & - & - & - & - & - & 7.99 \\
\hline 32 & - & 8.20 & - & 7.95 & 8.02 & - & - & 9.51 & 7.91 & 7.98 & 9.63 & - & - & - & - & 8.46 \\
\hline 33 & - & 8.48 & 8.36 & 8.28 & 7.98 & 8.39 & 8.68 & 9.25 & 9.05 & 7.88 & 9.08 & 9.40 & 9.42 & 8.96 & 7.92 & 8.65 \\
\hline 34 & $A$ & 7.93 & 8.39 & 8.25 & 7.23 & 7.38 & - & & 7.47 & 7.87 & 8.67 & - & 8.43 & - & 7.80 & 7.94 \\
\hline 35 & $S$ & 7.91 & 8.05 & 7.9 & 7.57 & 7.95 & & 8.38 & 7.71 & 7.87 & - & 8.76 & - & - & 7.43 & 7.95 \\
\hline 36 & $T$ & 8.12 & 7.96 & 7.79 & 7.49 & 8.16 & 7.92 & 9.03 & 8.25 & 7.72 & 8.51 & 8.93 & 8.91 & 7.76 & 7.85 & 8.17 \\
\hline 37 & - & - & - & - & - & - & - & 8.63 & 8.31 & 7.88 & 8.88 & 10.04 & 9.66 & 8.72 & 8.65 & 8.85 \\
\hline 38 & - & - & - & - & - & - & - & - & - & 7.78 & 8.83 & 10.06 & 9.70 & 8.64 & 8.67 & 8.95 \\
\hline 39 & - & - & - & - & 8.05 & - & - & - & - & - & 8.55 & - & - & - & - & 8.3 \\
\hline 40 & - & - & - & - & 8.04 & - & - & - & - & - & - & - & - & - & - & 8.04 \\
\hline 41 & - & - & - & 7.95 & 6.83 & - & - & - & - & - & - & - & - & - & - & 7.39 \\
\hline Mean & & 8.09 & 8.11 & 8.23 & 8.23 & 8.33 & \begin{tabular}{|l|l|}
8.81 \\
\end{tabular} & 9.24 & 8.92 & 7.73 & 8.67 & 9.01 & 9.52 & 8.45 & 7.84 & \\
\hline
\end{tabular}


Leon Waterflood - All Stations Temperature (C')

\begin{tabular}{|c|c|c|c|c|c|c|c|c|c|c|c|c|c|c|c|c|}
\hline Site & New \# & $4 / 4 / 01$ & $4 / 30 / 01$ & $5 / 9 / 01$ & $6 / 8 / 01$ & $7 / 23 / 01$ & $10 / 25 / 01$ & $3 / 1 / 02$ & $4 / 29 / 02$ & $6 / 14 / 02$ & $6 / 20 / 02$ & $7 / 19 / 02$ & $8 / 8 / 02$ & $9 / 23 / 02$ & $11 / 21 / 02$ & Mean \\
\hline 1 & $B$ & 15.7 & 20.8 & 22.6 & 23.4 & 29.6 & 13.5 & 3.3 & 23.5 & 24.1 & 28.8 & 26.9 & 30.3 & 17.8 & 8.6 & 20.6 \\
\hline 2 & $C$ & 15.5 & 19.8 & 23.6 & 23.3 & - & - & - & - & 27.3 & 34.5 & - & - & - & - & 24.0 \\
\hline 3 & $\mathrm{D}$ & 14.6 & 20.4 & 21 & 23.3 & - & - & - & - & - & - & - & - & - & 7.8 & $\begin{array}{l}17.4 \\
\end{array}$ \\
\hline 4 & $E$ & 13.4 & 18.4 & 21.7 & 23.2 & - & - & - & - & 23.4 & 28.6 & 27.5 & - & - & 7.4 & 20.5 \\
\hline 5 & $F$ & 14.5 & 20.1 & 21.9 & 22.8 & - & - & - & - & 22.1 & 29.5 & 26.2 & 33 & - & 7.4 & 21.9 \\
\hline 6 & $G$ & 14.4 & 20.1 & 21.6 & 22.4 & 30.8 & - & - & 25.1 & 23.2 & 27.4 & 26.5 & 28.6 & - & 7.6 & 22.5 \\
\hline 7 & $\mathrm{H}$ & 13.8 & 20.1 & 20.6 & 21.3 & 29.7 & - & - & 25 & 23.7 & 26.9 & 26.7 & 29.4 & - & 6.8 & 22.2 \\
\hline 8 & $\mathrm{I}$ & 14 & 19.6 & 21.1 & 20.9 & 26.6 & - & - & - & 23.2 & 26.4 & 25.7 & 27.7 & 16 & 7.1 & 20.8 \\
\hline 9 & $\mathrm{~J}$ & 14.4 & 19.9 & 22.9 & 20.4 & 30.2 & - & - & - & 23.8 & 30 & 26.9 & 28.2 & - & 8.1 & 22.5 \\
\hline 10 & & - & - & - & 21.6 & - & - & - & - & - & - & - & - & - & - & 21.6 \\
\hline 11 & $\mathrm{~K}$ & 14.7 & 20 & 22.3 & 23.2 & 30.9 & 13.6 & 3.3 & 23.3 & 23.7 & 28.9 & 27.6 & 29.4 & 18.6 & 8.8 & 20.6 \\
\hline 12 & $\mathrm{~L}$ & 14.8 & 20.2 & 22.4 & 23.7 & 29 & 13.6 & 3.4 & 21.5 & 24 & 26.2 & 27.8 & 29.6 & 18.6 & 9 & 20.3 \\
\hline 13 & $M$ & 16.3 & 22 & 28.7 & 23.4 & - & - & - & - & 25.3 & 31.2 & - & - & - & - & 24.5 \\
\hline 14 & & 15 & 20.3 & 26.3 & 21.7 & - & - & - & - & 23.3 & 25.8 & - & - & - & 8.1 & 20.1 \\
\hline 15 & $\mathrm{~N}$ & 14.7 & 18.9 & 23.2 & 23.5 & - & - & - & - & 25.9 & 27.1 & - & - & - & - & 22.2 \\
\hline 16 & & 15.5 & 21.5 & 27.1 & 23.4 & 34 & 12.6 & 2.9 & 26.1 & 27.9 & 31.6 & 26.3 & 34.8 & 19.7 & 9.2 & 22.3 \\
\hline 17 & & 15.9 & 20.1 & 24.6 & 23 & - & - & - & 24.9 & 26.2 & 29 & - & - & - & 9.5 & 21.7 \\
\hline 18 & & 14.7 & 20.6 & 23.5 & 20.7 & - & - & - & - & 25.7 & 29.2 & 33.1 & - & - & 8.8 & 22.0 \\
\hline 19 & & 14.4 & 20.6 & 22.7 & 20.1 & - & - & - & - & 24.1 & 23.2 & 32 & - & - & 10.4 & 20.9 \\
\hline 20 & 0 & 15 & $\begin{array}{l}19.8 \\
\end{array}$ & 24 & 23.2 & - & - & - & - & 26.4 & 27.9 & - & - & - & 9.4 & 20.8 \\
\hline 21 & $P$ & 15.8 & 20.4 & 27.2 & 23.1 & - & - & - & - & 26.6 & 30.3 & - & - & - & 10.7 & 22.0 \\
\hline 22 & & $\begin{array}{l}14.4 \\
\end{array}$ & 20.6 & 23.4 & 21.6 & - & - & - & - & 24 & 26.9 & 26.8 & - & - & 7.2 & 20.6 \\
\hline 23 & $Q$ & 15.2 & 19.7 & 24.2 & 22.9 & - & - & - & - & 27.3 & 29.8 & - & - & - & 8.8 & 21.1 \\
\hline 24 & $R$ & 15.2 & 21 & 22.1 & 21.7 & 31.7 & - & - & 22.5 & 25 & 28.3 & 26.2 & - & - & 8.7 & 22.2 \\
\hline 25 & & 11.6 & 16.4 & 17.5 & 19.9 & - & - & - & - & 20.3 & 22.3 & 27 & - & - & 12.4 & 18.4 \\
\hline 26 & & 14.9 & 19.7 & 23 & 23.4 & 31.1 & 13.2 & 2.6 & 25.3 & 26.9 & 28.6 & 28.3 & 31 & 18.6 & $\begin{array}{l}10.2 \\
\end{array}$ & 21.2 \\
\hline 27 & & 16.7 & - & - & 21.8 & - & - & - & 23.8 & 24.3 & 21.6 & - & - & - & 10.6 & 19.8 \\
\hline 28 & & 15.2 & 20.6 & 27.8 & 22 & 27.4 & - & - & - & 22 & 30.1 & 25.3 & - & - & 13.4 & 22.6 \\
\hline 29 & & 16 & 19.5 & 24.9 & 21.3 & 25.5 & 11.2 & 3.1 & 22.7 & 23.3 & 23.9 & 25.1 & 24.3 & 15.7 & 8.9 & 19.0 \\
\hline 30 & & 17.8 & 20.7 & 24.2 & 21.2 & - & - & - & - & - & - & - & - & - & - & 21.0 \\
\hline 31 & & 19.7 & - & 27.3 & 22.4 & - & - & - & - & - & - & - & - & - & - & 23.1 \\
\hline 32 & & 20.7 & - & 28.3 & 22.7 & - & - & 3.1 & 24.7 & 25.4 & 36 & - & - & - & - & 23.0 \\
\hline 33 & & 16.3 & 20.2 & 23.7 & 23.3 & 29.7 & 13.5 & 3 & 24 & 24 & 28.6 & 28.1 & 33 & 18.7 & 10.2 & 21.2 \\
\hline 34 & $A$ & 15.5 & 18.6 & 19.5 & 20.8 & 25.5 & - & - & 20.2 & 22.1 & 23.5 & - & 23.1 & - & 6.1 & 19.5 \\
\hline 35 & $S$ & 19 & 18.1 & 20.2 & 20.8 & 24.9 & - & 0.9 & 14.6 & 23.9 & - & 23.3 & - & - & 7.1 & 17.3 \\
\hline 36 & $T$ & 15.2 & $\begin{array}{l}18.8 \\
\end{array}$ & 20.5 & 20.4 & 29.2 & 13.1 & 3.4 & 18.8 & 22.6 & 25 & 26.6 & 28 & 18.6 & 7.3 & 19.1 \\
\hline 37 & & - & - & - & - & - & - & 4.1 & 23.7 & 23.1 & 27.1 & 26.5 & 28.3 & 18.2 & 10.7 & 20.2 \\
\hline 38 & & - & - & - & - & - & - & - & - & 22.6 & 28.9 & 27.5 & 29.5 & 17.3 & 9.8 & 22.6 \\
\hline 39 & & - & - & - & 21.1 & - & - & - & - & - & 27.5 & - & - & - & - & 24.3 \\
\hline 40 & & - & - & - & 23.2 & - & - & - & - & - & - & - & - & - & - & 23.2 \\
\hline 41 & & - & - & 21.8 & 22.1 & - & - & - & - & - & - & - & - & - & - & 22.0 \\
\hline Mean & & 15.4 & 19.9 & 23.4 & 22.2 & 29.1 & 13.0 & 3.0 & 22.9 & 24.3 & 28.0 & 27.1 & 29.3 & 18.0 & 8.9 & \\
\hline
\end{tabular}




\section{Leon Waterflood - All Station Turbidity}

\begin{tabular}{|c|c|c|c|c|c|c|c|c|c|c|c|c|c|c|c|c|}
\hline Site & New \# & $4 / 4 / 01$ & $4 / 30 / 01$ & $5 / 9 / 01$ & 6/8/01 & $7 / 23 / 01$ & $10 / 25 / 01$ & $3 / 1 / 02$ & $4 / 29 / 02$ & $6 / 14 / 02$ & $6 / 20 / 02$ & $7 / 19 / 02$ & $8 / 8 / 02$ & 9/23/02 & $11 / 21 / 02$ & Mean \\
\hline 1 & $B$ & 8 & 6 & 11 & 13 & 17 & 11 & 20 & 77 & 11 & 17 & 13 & 23 & 62 & 4 & 21 \\
\hline 2 & $C$ & 6 & 24 & 11 & 17 & - & - & - & - & 52 & 59 & - & - & - & - & 28 \\
\hline 3 & $\mathrm{D}$ & 15 & 52 & 7 & 26 & - & - & - & - & - & - & - & - & - & 9 & 22 \\
\hline 4 & $E$ & 11 & 16 & 10 & 31 & - & - & - & - & 13 & 15 & 11 & - & - & 6 & 14 \\
\hline 5 & $F$ & 16 & 39 & 24 & 22 & - & - & - & - & 39 & 16 & 35 & 38 & - & 5 & 26 \\
\hline 6 & $G$ & 11 & 13 & 8 & 52 & 47 & - & - & 57 & 33 & 18 & 15 & 76 & - & 1 & 30 \\
\hline 7 & $\mathrm{H}$ & 4 & 5 & 3 & 90 & 30 & - & - & 30 & 54 & 9 & 26 & 94 & - & 0 & 31 \\
\hline 8 & $\mathrm{I}$ & 12 & 6 & 22 & 54 & 43 & - & - & - & 40 & 61 & 13 & 9 & 17 & 15 & 27 \\
\hline 9 & $\mathrm{~J}$ & 21 & 6 & 14 & 150 & 50 & - & - & - & 29 & 152 & 7 & 11 & - & 8 & 45 \\
\hline 10 & & - & - & - & 63 & - & - & - & - & - & - & - & - & - & - & 63 \\
\hline 11 & $\mathrm{~K}$ & 22 & 6 & 17 & 17 & 84 & 19 & 30 & 52 & 47 & 123 & 16 & 14 & 23 & 3 & 34 \\
\hline 12 & $\mathrm{~L}$ & 27 & 8 & 5 & 11 & 36 & 25 & 26 & 54 & 69 & 97 & 16 & 15 & 21 & 11 & 30 \\
\hline 13 & $M$ & 20 & 114 & 7 & 16 & - & - & - & - & 45 & 92 & - & - & - & - & 49 \\
\hline 14 & & 4 & 11 & 8 & 93 & - & - & - & - & 22 & 6 & - & - & - & 3 & 21 \\
\hline 15 & $\mathrm{~N}$ & 15 & 27 & 17 & 29 & - & - & - & - & 41 & 28 & - & - & - & - & 26 \\
\hline 16 & & 37 & 77 & 207 & 108 & 250 & 119 & 47 & 477 & 57 & 106 & 135 & 132 & 300 & 9 & 147 \\
\hline 17 & & 12 & 9 & 35 & 137 & - & - & - & 22 & 179 & 90 & - & - & - & 8 & 62 \\
\hline 18 & & 5 & 4 & 5 & 377 & - & - & - & - & 60 & 29 & 46 & - & - & 5 & 66 \\
\hline 19 & & 2 & 3 & 10 & 302 & - & - & - & - & 10 & 9 & 215 & - & - & 8 & 70 \\
\hline 20 & $\mathrm{O}$ & 57 & 23 & 20 & 23 & - & - & - & - & 33 & 23 & - & - & - & 0 & 26 \\
\hline 21 & $P$ & 22 & 10 & 33 & 70 & - & - & - & - & 31 & 22 & - & - & - & 12 & 29 \\
\hline 22 & & 4 & 20 & 12 & 279 & - & - & - & - & 2 & 8 & 59 & - & - & 7 & 49 \\
\hline 23 & $Q$ & 27 & 11 & 11 & 59 & - & - & - & - & 55 & 19 & - & - & - & 10 & 27 \\
\hline 24 & $R$ & 5 & 9 & 3 & 174 & 112 & - & - & 6 & 52 & 34 & 30 & - & - & 3 & 43 \\
\hline 25 & & 4 & 76 & 29 & 198 & - & - & - & - & 7 & 8 & 27 & - & - & 2 & 44 \\
\hline 26 & & 64 & 24 & 27 & 42 & 34 & 23 & 181 & 130 & 87 & 100 & 22 & 28 & 38 & 19 & 59 \\
\hline 27 & & 4 & - & - & 39 & - & - & - & 150 & 4 & 14 & - & - & - & 10 & 37 \\
\hline 28 & & 5 & 41 & 125 & 35 & $999+$ & - & - & - & 5 & 94 & 184 & - & - & 193 & 85 \\
\hline 29 & & 74 & 274 & 430 & 281 & 418 & 198 & 212 & 137 & 68 & 33 & 158 & 262 & $999+$ & 56 & 200 \\
\hline 30 & & 21 & 8 & 41 & 118 & - & - & - & - & - & - & - & - & - & - & 47 \\
\hline 31 & & 51 & - & 139 & 59 & - & - & - & - & - & - & - & - & - & - & 83 \\
\hline 32 & & 9 & - & 270 & $999+$ & - & - & 51 & $999+$ & 670 & 77 & - & - & - & - & 215 \\
\hline 33 & & 87 & 81 & 83 & 114 & 193 & 59 & 42 & 406 & 129 & 115 & 47 & 18 & 36 & 38 & 103 \\
\hline 34 & $A$ & 16 & 26 & 110 & 98 & 70 & - & - & 85 & 123 & 43 & - & 41 & - & 32 & 64 \\
\hline 35 & $S$ & 4 & 4 & 13 & 128 & 190 & - & 33 & 0 & 30 & - & 41 & - & - & 3 & 45 \\
\hline 36 & $T$ & 32 & 27 & 47 & 246 & 67 & 32 & 17 & 38 & 266 & 144 & 35 & 50 & 49 & 20 & 76 \\
\hline 37 & & - & - & - & - & - & - & 10 & 107 & 552 & 475 & 82 & 68 & 52 & 35 & 173 \\
\hline 38 & & - & - & - & - & - & - & - & - & 550 & 516 & 105 & 60 & 161 & 30 & 237 \\
\hline 39 & & - & - & - & 68 & - & - & - & - & - & 11 & - & - & - & - & 40 \\
\hline 40 & & - & - & - & 241 & - & - & - & - & - & - & - & - & - & - & 241 \\
\hline 41 & & - & - & 31 & 32 & - & - & - & - & - & - & - & - & - & - & 32 \\
\hline Mean & & 21 & 33 & 53 & 103 & 109 & 61 & 61 & 114 & 102 & 78 & 58 & 59 & 76 & 18 & \\
\hline & & & & & & & & & & & & & & & & \\
\hline & & & ote: Turb & dity valu & were $\mathrm{v}$ & riously af & ted by & ence & sattle at & ral san & sites. & & & & & \\
\hline
\end{tabular}


Leon Waterflood - Comparison of 2001/2002 Conductivity (uS/cm)

\begin{tabular}{|c|c|c|c|c|}
\hline Site & New \# & 2001 Means & 2002 Means & Change \\
\hline 34 & A & 240 & 202 & decrease \\
\hline 1 & B & 679 & 526 & decrease \\
\hline 2 & C & 720 & 331 & decrease \\
\hline 3 & D & 816 & 2230 & increase \\
\hline 4 & E & 868 & 946 & increase \\
\hline 5 & F & 1000 & 957 & decrease \\
\hline 6 & G & 1224 & 1349 & increase \\
\hline 7 & H & 1327 & 1298 & decrease \\
\hline 8 & I & 1254 & 592 & decrease \\
\hline 9 & J & 856 & 453 & decrease \\
\hline 11 & $\mathbf{K}$ & 886 & 725 & decrease \\
\hline 12 & $\mathbf{L}$ & 888 & 679 & decrease \\
\hline 13 & $\mathbf{M}$ & 1331 & 402 & decrease \\
\hline 15 & $\mathbf{N}$ & 1406 & 647 & decrease \\
\hline 20 & $\mathbf{O}$ & 1681 & 1300 & decrease \\
\hline 21 & $\mathbf{P}$ & 1826 & 1530 & decrease \\
\hline 23 & $\mathbf{Q}$ & 1706 & 1450 & decrease \\
\hline 24 & $\mathbf{R}$ & 1274 & 1180 & decrease \\
\hline 35 & $\mathbf{S}$ & 888 & 1310 & increase \\
\hline 36 & $\mathbf{T}$ & 399 & 428 & increase \\
\hline Mean & & 1063 & 926 & decrease \\
\hline
\end{tabular}




\section{APPENDIX III - Plant Census Data}

Plant cover at the Leon Water Flood, for June and October 2001 sampling dates. When cover of a species is less than $0.005 \%$, $T$ denotes a trace of cover.

\begin{tabular}{|c|c|c|c|c|c|}
\hline & & $\underline{\text { Tank }}$ & Scar & Large & Scar \\
\hline Scientific name & Common name & $\underline{\text { June }}$ & October & June & October \\
\hline Agropyron smithii & western wheatgrass & $0.1 \%$ & $\overline{\mathrm{T}}$ & $\overline{0.1 \%}$ & $0.1 \%$ \\
\hline Ambrosia psilostachya & western ragweed & $0.1 \%$ & $1.2 \%$ & $0.0 \%$ & $0.4 \%$ \\
\hline Ambrosia artemisiafolia & common ragweed & $0.9 \%$ & $0.9 \%$ & $0.3 \%$ & $0.5 \%$ \\
\hline Andropogon gerardii & big bluestem & $\mathrm{T}$ & $0.2 \%$ & $0.0 \%$ & $0.1 \%$ \\
\hline Andropogon scoparium & little bluestem & $0.0 \%$ & $\mathrm{~T}$ & $0.0 \%$ & $\mathrm{~T}$ \\
\hline Bouteloua curtipendula & side-oats grama & $0.1 \%$ & $0.8 \%$ & $0.1 \%$ & $0.3 \%$ \\
\hline Bouteloua gracilis & blue grama & $0.1 \%$ & $\mathrm{~T}$ & $0.0 \%$ & $T$ \\
\hline Bromus japonicus & Japanese brome & $2.2 \%$ & $0.1 \%$ & $0.0 \%$ & $0.3 \%$ \\
\hline Buchloe dactyloides & buffalograss & $0.1 \%$ & $0.2 \%$ & $0.8 \%$ & $0.6 \%$ \\
\hline Chloris verticillata & windmill grass & $0.0 \%$ & $\mathrm{~T}$ & $\mathrm{~T}$ & $\mathrm{~T}$ \\
\hline Cyperus esculentus & yellow nutsedge & $0.4 \%$ & $0.1 \%$ & $0.2 \%$ & $0.2 \%$ \\
\hline Desmanthus illinoensis & Illinois bundleflower & $0.5 \%$ & $0.7 \%$ & $0.1 \%$ & $0.3 \%$ \\
\hline Dichanthelium acuminatum & hairy dichanthelium & $0.0 \%$ & $0.1 \%$ & $0.0 \%$ & $\mathrm{~T}$ \\
\hline Dichanthelium oligosanthes & $\begin{array}{l}\text { Scribner's } \\
\text { dichanthelium }\end{array}$ & $0.1 \%$ & $0.0 \%$ & $\mathrm{~T}$ & $\mathrm{~T}$ \\
\hline Digitaria ischaemum & smooth crabgrass & $1.9 \%$ & $1.1 \%$ & $0.4 \%$ & $0.8 \%$ \\
\hline Distichlis spicata & Saltgrass & $0.2 \%$ & $0.7 \%$ & $0.4 \%$ & $0.5 \%$ \\
\hline Echinochloa crusgalli & $\begin{array}{l}\text { common } \\
\text { barnyardgrass }\end{array}$ & $0.1 \%$ & $0.6 \%$ & $0.0 \%$ & $0.2 \%$ \\
\hline Elymus canadensis & Canada wildrye & $0.1 \%$ & $0.0 \%$ & $\mathrm{~T}$ & $\mathrm{~T}$ \\
\hline Eriochloa contracta & prairie cupgrass & $0.0 \%$ & $0.0 \%$ & $0.1 \%$ & $\mathrm{~T}$ \\
\hline Euphorbia corollata & flowering spurge & $\mathrm{T}$ & $0.0 \%$ & $0.0 \%$ & $\mathrm{~T}$ \\
\hline Euphorbia serpens & ridge-seeded spurge & $0.3 \%$ & $3.2 \%$ & $0.1 \%$ & $1.0 \%$ \\
\hline Euphorbia maculata & mat spurge & $0.0 \%$ & $0.0 \%$ & $0.0 \%$ & $\mathrm{~T}$ \\
\hline Euphorbia marginata & snow-on-the-mountain & $\mathrm{T}$ & $0.3 \%$ & $0.0 \%$ & $0.1 \%$ \\
\hline Euthamia graminiflora & grass-leaved goldenrod & $0.0 \%$ & $0.0 \%$ & $\mathrm{~T}$ & $T$ \\
\hline Euthamia gynospermnoides & viscid euthamia & $0.7 \%$ & $0.0 \%$ & $0.3 \%$ & $0.2 \%$ \\
\hline Gutierrizia dracunculoides & broomweed & $0.0 \%$ & $5.6 \%$ & $0.1 \%$ & $1.6 \%$ \\
\hline Helianthus annuus & common sunflower & $0.0 \%$ & $3.3 \%$ & $0.1 \%$ & $1.0 \%$ \\
\hline Hibiscus trionum & flower-of-an-hour & $0.7 \%$ & $6.0 \%$ & $0.3 \%$ & $2.0 \%$ \\
\hline Hordeum jubatum & foxtail barley & $0.4 \%$ & $0.2 \%$ & $0.2 \%$ & $0.2 \%$ \\
\hline Hordeum pusillum & little barley & $\mathrm{T}$ & $0.0 \%$ & $0.0 \%$ & $\mathrm{~T}$ \\
\hline Iva annua & annual sumpweed & $\mathrm{T}$ & $\mathrm{T}$ & $0.0 \%$ & $\mathrm{~T}$ \\
\hline Kochia scoparia & summer cypress & $0.1 \%$ & $4.3 \%$ & $\mathrm{~T}$ & $1.2 \%$ \\
\hline Leptochloa fascicularis & bearded sprangletop & $0.0 \%$ & $0.8 \%$ & $0.0 \%$ & $0.2 \%$ \\
\hline Panicum capillare & witchgrass & $\mathrm{T}$ & $0.0 \%$ & $0.0 \%$ & $\mathrm{~T}$ \\
\hline Panicum dichotimiflorum & fall panicum & $0.0 \%$ & $0.5 \%$ & $\mathrm{~T}$ & $0.2 \%$ \\
\hline Panicum virgatum & switchgrass & $0.0 \%$ & $0.3 \%$ & $0.2 \%$ & $0.2 \%$ \\
\hline Poa arida & plains bluegrass & $0.3 \%$ & $0.4 \%$ & $\mathrm{~T}$ & $0.2 \%$ \\
\hline Polygonum ramosissimum & knotweed & $0.1 \%$ & $0.0 \%$ & $0.0 \%$ & $\mathrm{~T}$ \\
\hline Schedonnardus paniculatus & tumblegrass & $\mathrm{T}$ & $0.0 \%$ & $0.1 \%$ & $\mathrm{~T}$ \\
\hline Solanum rostratum & buffalo bur & $1.2 \%$ & $1.4 \%$ & $0.1 \%$ & $0.6 \%$ \\
\hline
\end{tabular}




\begin{tabular}{|l|l|r|r|r|r|}
\hline Setaria faberi & Chinese foxtail & $0.3 \%$ & $0.0 \%$ & $0.1 \%$ & $0.1 \%$ \\
\hline Sorghastrum nutans & Indiangrass & $0.1 \%$ & $0.2 \%$ & $\mathrm{~T}$ & $0.1 \%$ \\
\hline Sporobolus airoides & alkali sacaton & $0.3 \%$ & $4.3 \%$ & $1.0 \%$ & $1.8 \%$ \\
\hline Sporobolus asper & rough dropseed & $0.2 \%$ & $\mathrm{~T}$ & $0.0 \%$ & $\mathrm{~T}$ \\
\hline Sporobolus cryptandrus & sand dropseed & $0.0 \%$ & $0.3 \%$ & $\mathrm{~T}$ & $0.1 \%$ \\
\hline Sporobolus vaginiflorus & poverty grass & $0.0 \%$ & $0.3 \%$ & $0.0 \%$ & $0.1 \%$ \\
\hline Verbena stricta & woolly verbena & $\mathrm{T}$ & $\mathrm{T}$ & $\mathrm{T}$ & $0.1 \%$ \\
\hline & & & & & \\
\hline Total Vegetative Cover & & $\mathbf{1 1 . 9} \%$ & $\mathbf{3 8 . 2} \%$ & $\mathbf{5 . 0} \%$ & $\mathbf{1 5 . 1 \%}$ \\
\hline Bare Ground & & $\mathbf{8 7 . 6 \%}$ & $\mathbf{6 1 . 6 \%}$ & $\mathbf{9 4 . 8 \%}$ & $\mathbf{8 4 . 6 \%}$ \\
\hline & & & & & \\
\hline Total & & $100.0 \%$ & $100.0 \%$ & $100.0 \%$ & $100.0 \%$ \\
\hline
\end{tabular}


Presence of plant species at the Leon Water Flood large scar in June 2002, for each of six experimental treatments.

\begin{tabular}{|c|c|c|c|c|c|c|}
\hline \\
\hline & Control & Gypsum & Manure & Sand & Tillage & Topsoil \\
\hline Agropyron intermedia & & & & & & $\overline{\mathrm{x}}$ \\
\hline Agropyron smithii & $x$ & $x$ & & $x$ & $x$ & \\
\hline Amaranthus graecizans & & & & & & $\mathrm{x}$ \\
\hline Amaranthus rudis & & & & & & $x$ \\
\hline Amaranthus spinosus & & & & & & $x$ \\
\hline Ambrosia artemisiafolia & $x$ & $x$ & $x$ & $x$ & $x$ & $\mathrm{x}$ \\
\hline Ambrosia psilostachya & & $x$ & & $x$ & $x$ & \\
\hline Ambrosia trifida & & & & & & $x$ \\
\hline Andropogon gerardii & & $x$ & & & $\mathrm{x}$ & \\
\hline Andropogon scoparium & & & & & & $x$ \\
\hline Aster subulatus & & & & & $\mathrm{x}$ & $x$ \\
\hline Avena sativa & & & $x$ & & & \\
\hline Bouteloua curtipendula & $x$ & & & & $x$ & $x$ \\
\hline Bromus japonicus & $x$ & & & & & \\
\hline Buchloe dactyloides & $x$ & & $x$ & & $x$ & $x$ \\
\hline Cassia fasciculata & & & & $x$ & & \\
\hline Chenopodium berlandieri & & & $\mathrm{x}$ & $x$ & & $\mathrm{x}$ \\
\hline Convolvulus arvensis & & & & $x$ & & \\
\hline Conyza canadensis & & & & & & $x$ \\
\hline Croton monanthogynous & & & & $\mathrm{x}$ & & \\
\hline Cycloloma atriplicifolia & & & $x$ & & & $x$ \\
\hline Cynodon dactylon & & & & & & $\mathrm{x}$ \\
\hline Cyperus esculentus & $x$ & $x$ & $x$ & $x$ & $x$ & $x$ \\
\hline Desmanthus illinoiense & $x$ & & & & $x$ & \\
\hline Digitaria ischaemum & $x$ & & $\mathrm{x}$ & $\mathrm{x}$ & & $\mathrm{x}$ \\
\hline Distichlis spicata & $\mathrm{x}$ & $x$ & & $x$ & & $x$ \\
\hline Echinochloa crusgalli & $x$ & $x$ & $\mathrm{x}$ & $\mathrm{x}$ & $x$ & $x$ \\
\hline Elymus canadensis & $x$ & & & & & \\
\hline Euphorbia maculata & & & & $x$ & & $x$ \\
\hline Euphorbia marginata & $x$ & $x$ & $\mathrm{x}$ & $\mathrm{x}$ & $x$ & $x$ \\
\hline Euphorbia serpens & & & & & & $\mathrm{x}$ \\
\hline Euthamia graminiflora & & & & & & $x$ \\
\hline Euthamia gynospermnoide & & & $x$ & $x$ & $x$ & $x$ \\
\hline Festuca arundinacea & & & $x$ & & & \\
\hline Geranium carolinianum & & & & & & $x$ \\
\hline Gutierrizia dracunculoides & & & $\mathrm{x}$ & & & \\
\hline Helianthus annuus & $\mathrm{x}$ & & $\mathrm{x}$ & $x$ & & $x$ \\
\hline Helianthus maximillianii & & & & $\mathrm{x}$ & & \\
\hline Hibiscus trionum & $x$ & $x$ & $x$ & $x$ & $x$ & $x$ \\
\hline Hordeum jubatum & $x$ & $x$ & $x$ & $x$ & & $x$ \\
\hline Iva annua & $x$ & $x$ & $x$ & $x$ & $x$ & $x$ \\
\hline Kochia scoparia & $x$ & $x$ & $x$ & $\mathrm{x}$ & $x$ & $x$ \\
\hline Lactuca serriola & & & & & & $x$ \\
\hline Lepidium densiflorum & & & & & & $x$ \\
\hline
\end{tabular}




\begin{tabular}{|c|c|c|c|c|c|c|}
\hline Leptochloa fasciculata & $\mathrm{x}$ & $\mathrm{x}$ & $\mathrm{x}$ & $\mathrm{x}$ & $\mathrm{x}$ & $\mathrm{x}$ \\
\hline Medicago Iupulina & $x$ & & $\mathrm{x}$ & & & $x$ \\
\hline Melilotus officinalis & & $x$ & $\mathrm{x}$ & $\mathrm{x}$ & $x$ & $x$ \\
\hline Mollugo verticillata & & & & & & $\mathrm{x}$ \\
\hline Oxalis corniculata & & & $\mathrm{x}$ & $x$ & $\mathrm{x}$ & $x$ \\
\hline Panicum capillare & & & & $x$ & & $x$ \\
\hline Panicum virgatum & $x$ & & & $x$ & $x$ & $x$ \\
\hline Poa arida & & $x$ & & & $x$ & \\
\hline Polygonum bicorne & & & & & & $x$ \\
\hline Polygonum ramosissimum & $x$ & $x$ & $\mathrm{x}$ & $x$ & $x$ & $x$ \\
\hline Populus deltoides & $x$ & $x$ & & & $x$ & $x$ \\
\hline Rumex crispus & & & $x$ & & & $x$ \\
\hline Setaria viridis & & & & $x$ & $x$ & $x$ \\
\hline Solanum carolinense & & & & $\mathrm{x}$ & & \\
\hline Solanum rostratum & & & $\mathrm{x}$ & $\mathrm{x}$ & & $\mathrm{x}$ \\
\hline Sonchus arvensis & & & & & & $x$ \\
\hline Sorghastrum nutans & $x$ & & $x$ & & & \\
\hline Sorghum halpens & & & & & & $x$ \\
\hline Spartina pectinata & $x$ & & $x$ & & & \\
\hline Sporobolus airoides & $\mathrm{x}$ & $x$ & & & $x$ & \\
\hline Sporobolus vaginiflorus & $\mathrm{x}$ & & & & & $x$ \\
\hline Verbena stricta & $x$ & & & & & $\mathrm{x}$ \\
\hline Xanthium strumarium & $x$ & & $x$ & $x$ & $x$ & $x$ \\
\hline Species Richness & 28 & 18 & 27 & 30 & 25 & 49 \\
\hline & & & & & & \\
\hline & & & & & & \\
\hline & & & & & & \\
\hline
\end{tabular}




\begin{tabular}{|c|c|c|c|c|c|c|}
\hline \multicolumn{7}{|c|}{$\begin{array}{l}\text { Presence of plant species at the Leon Water Flood large scar in September 2002, for each of } \\
\text { six experimental treatments. }\end{array}$} \\
\hline & & & & & & \\
\hline & Control & Gypsum & Manure & Sand & Tillage & Topsoil \\
\hline Agropyron smithii & $\bar{x}$ & & & & & \\
\hline Amaranthus rudis & & & $x$ & & $x$ & $x$ \\
\hline Ambrosia artemisiafolia & $x$ & $x$ & $x$ & $x$ & $x$ & $x$ \\
\hline Aristida oligantha & & & & & $x$ & \\
\hline Bouteloua curtipendula & $\mathrm{x}$ & & & & & \\
\hline Buchloe dactyloides & $x$ & & $x$ & $x$ & $x$ & $x$ \\
\hline Cassia fasciculata & & & $x$ & & & \\
\hline Chenopodium berlandieri & & & $x$ & & $\mathrm{x}$ & $x$ \\
\hline Cynodon dactylon & & $x$ & $x$ & $x$ & $x$ & $x$ \\
\hline Cyperus esculentus & $x$ & $\mathrm{x}$ & $x$ & & $x$ & \\
\hline Desmanthus illinoiense & & & & & $\mathrm{x}$ & \\
\hline Distichlis spicata & $x$ & $x$ & $x$ & $x$ & $x$ & $x$ \\
\hline Echinochloa crusgalli & & $x$ & $x$ & $\mathrm{x}$ & $\mathrm{x}$ & $x$ \\
\hline Euphorbia maculata & & $\mathrm{x}$ & $x$ & $\mathrm{x}$ & $\mathrm{x}$ & $x$ \\
\hline Euphorbia marginata & $x$ & & $x$ & $x$ & $x$ & $x$ \\
\hline Euthamia gynospermnoides & & & & $x$ & & $x$ \\
\hline Gutierrizia dracunculoides & $x$ & & $x$ & & $x$ & $x$ \\
\hline Helianthus annuus & & & $x$ & $x$ & & $x$ \\
\hline Iva annua & $x$ & $\mathrm{x}$ & $\mathrm{x}$ & $\mathrm{x}$ & $\mathrm{x}$ & \\
\hline Kochia scoparia & & $x$ & $x$ & $x$ & & \\
\hline Leptochloa fasciculata & $x$ & $\mathrm{x}$ & $x$ & $\mathrm{x}$ & $\mathrm{x}$ & $\mathrm{x}$ \\
\hline Panicum dichotimiflorum & & & $\mathrm{x}$ & & & $\mathrm{x}$ \\
\hline Panicum virgatum & $x$ & $x$ & $x$ & $x$ & $x$ & $x$ \\
\hline Physalis longifolia & & & $x$ & & & \\
\hline Poa arida & $x$ & & $\mathrm{x}$ & $\mathrm{x}$ & $\mathrm{x}$ & \\
\hline Polygonum arenastrum & & & $x$ & & & \\
\hline Polygonum ramosissimum & $x$ & $x$ & $x$ & $x$ & $x$ & $x$ \\
\hline Solanum rostratum & & & $x$ & & & $x$ \\
\hline Sorghastrum nutans & $x$ & & & & $x$ & \\
\hline Sorghum halpens & & & $\mathrm{x}$ & & $x$ & $\mathrm{x}$ \\
\hline Spartina pectinata & $x$ & & & & & \\
\hline Sporobolus airoides & $x$ & $x$ & $x$ & $x$ & $x$ & $x$ \\
\hline Sporobolus asper & & & & & $\mathrm{x}$ & \\
\hline Sporobolus vaginiflorus & & & & & $x$ & \\
\hline Xanthium strumarium & & & & $x$ & & \\
\hline Species Richness & 16 & 12 & 25 & 17 & 23 & 19 \\
\hline
\end{tabular}

